\title{
51. EVOLUTION OF THE VØRING VOLCANIC MARGIN ${ }^{1}$
}

\author{
Olav Eldholm, ${ }^{2}$ Jörn Thiede, ${ }^{3}$ and Elliott Taylor ${ }^{4,5}$
}

\begin{abstract}
ODP Sites 642 and 643 recovered a succession of rocks which have greatly improved the understanding of how the Cenozoic volcanic Vøring Margin evolved, particularly by providing important constraints on the series of events that occurred during the initial opening of the Norwegian-Greenland Sea. The more than $900 \mathrm{~m}$ of igneous rocks and interbedded sediments drilled at Site 642 constitute two distinct, strikingly different volcanic series. The upper series, composed of transitional mid-oceanic tholeiitic lava flows and thin interbedded volcaniclastic sediments confirmed the seaward-dipping reflectors to be a terrestrially constructed extrusive complex. The lower series, probably extending for several hundred meters below the bottom of the hole, consists of another flow complex of dacitic composition, some dikes and thicker interbedded sediments, partially continentally derived. We suggest that the margin evolved by crustal extension in the Paleocene accompanied by uplift and a progressively more intense invasion of dikes and sills in the rift zone. Just prior to breakup, magma from shallow crustal melts produced the lower series. The upper series was constructed during an intense, rapidly waning, volcanic surge of subaerial accretion of oceanic magma following breakup in middle of Chron 24.2R. The surge is characterized by a much increased rate of magma production and high spreading rate. The upper series cover both newly formed oceanic crust and large areas of the adjacent thinned continental crust. The dipping wedge was formed by subsidence due to loading and thermal contraction, possibly amplified by a tectonic force. When the surge had abated, the injection center quickly subsided and normal oceanic crust was formed. Our interpretation is that the continent/ocean boundary occurs at the seaward termination of reflector $\mathrm{K}$, which separates the two volcanic series. However, a region of strongly intruded transitional crust is inferred in 30- to $50-\mathrm{km}$ wide zones on either side of the Vøring Plateau Escarpment.

The Vøring Margin experienced crustal uplift and extension prior to breakup, restricted to a Tertiary marginal basin west of the present shelf edge. The initial volcanic surge and shallow extrusion level are related to a higher than normal temperature at the base of the lithosphere, inducing partial melting combined with opening in previously thinned crust. The commonly described non-extensional nature of this margin is only an apparent phenomenon. Except for the outer basin, extension by dike injection coupled with high strength of the thin, pre-opening crust in the Vøring Basin precluded the formation of a faulted rift unconformity. We believe these observations have relevance for volcanic margins elsewhere, but infer that seaward-dipping reflectors can form in many environments.

The Vøring Plateau marginal high and other similar features in the North Atlantic are an integrated part of the North Atlantic Volcanic Province, which extends $2000 \mathrm{~km}$ longitudinally. Compared to the central, transverse, part of the province in the vicinity of the Iceland hotspot that has been active for $60 \mathrm{~m}$.y., marginal volcanism was transient, related to breakup and lasting only for a maximum of about 3 m.y.
\end{abstract}

\section{INTRODUCTION}

Drilling at the Vøring Plateau off Norway (Fig. 1) during Leg 104 of the Ocean Drilling Program (ODP) was designed to address two main scientific objectives. First, to drill into a seaward-dipping reflector sequence at a buried marginal high to obtain information on the sequence of events taking place during continental breakup, leading to the formation of oceanic crust by seafloor spreading. In particular, we study the initial evolution of the volcanic type of a rifted passive continental margin. Second, to recover sediments from a short transect of drill holes at the outer margin to elucidate the paleoceanographic and paleoclimatic evolution of the Norwegian Margin and the Norwegian-Greenland Sea. Because of these different objectives, we present two separate synthesis papers. This study deals with the evolution of the Vøring continental margin, with an emphasis on early Tertiary events and the emplacement of igneous rocks during the initial stage of margin development. The

\footnotetext{
${ }^{1}$ Eldholm, O., Thiede, J., Taylor, E., et al., 1989. Proc. ODP, Sci. Results, 104: College Station, TX (Ocean Drilling Program)

2 Department of Geology, University of Oslo, Oslo, Norway.

${ }^{3}$ GEOMAR Research Center for Marine Geosciences, Kiel, Federal Republic of Germany.

4 Ocean Drilling Program, Texas A\&M University, College Station, TX 77840.
5 Now at School of Oceanography, University of Washington, Seattle, WA 98195.
}

main paleoenvironmental results and inferences are presented in the accompanying chapter by Thiede et al. (this volume).

On Leg 104 we drilled a short transect consisting of eight holes at three sites across the Vøring Plateau (Figs. 1 and 2). The drilling objectives and results have been described by Eldholm, Thiede, Taylor et al. (1987) and in the introductory chapter to this volume. Site 644 in the Vøring Basin is a paleoenvironmental site. We concentrate on Site 642 on top of the marginal high, which drilled to a total depth of $1229.4 \mathrm{mbsf}$ and penetrated more than $900 \mathrm{~m}$ volcanic rocks, and Site 643 at the foot of the plateau, which drilled through $\mathbf{5 6 5 . 2}$ of sediments to the top of the underlying basement.

We first describe the geological setting of the ODP sites, review previous models for the evolution of the seaward-dipping reflector sequences and the continent/ocean boundary, and summarize the most relevant drilling results. Then, by integrating the drilling results, geophysical data, and other geological information, we discuss the early opening history and subsequent evolution of the Vøring Margin and relate it to other early Tertiary volcanic events in the North Atlantic region. Finally, we make some inferences applicable to volcanic rifted continental margins in general.

\section{VORING PLATEAU MARGINAL HIGH}

Along the entire outer continental margin off Norway, there is a distinct, complex geological province between oceanic crust in the deep Norway and Lofoten Basins (Fig. 1) and the sedi- 


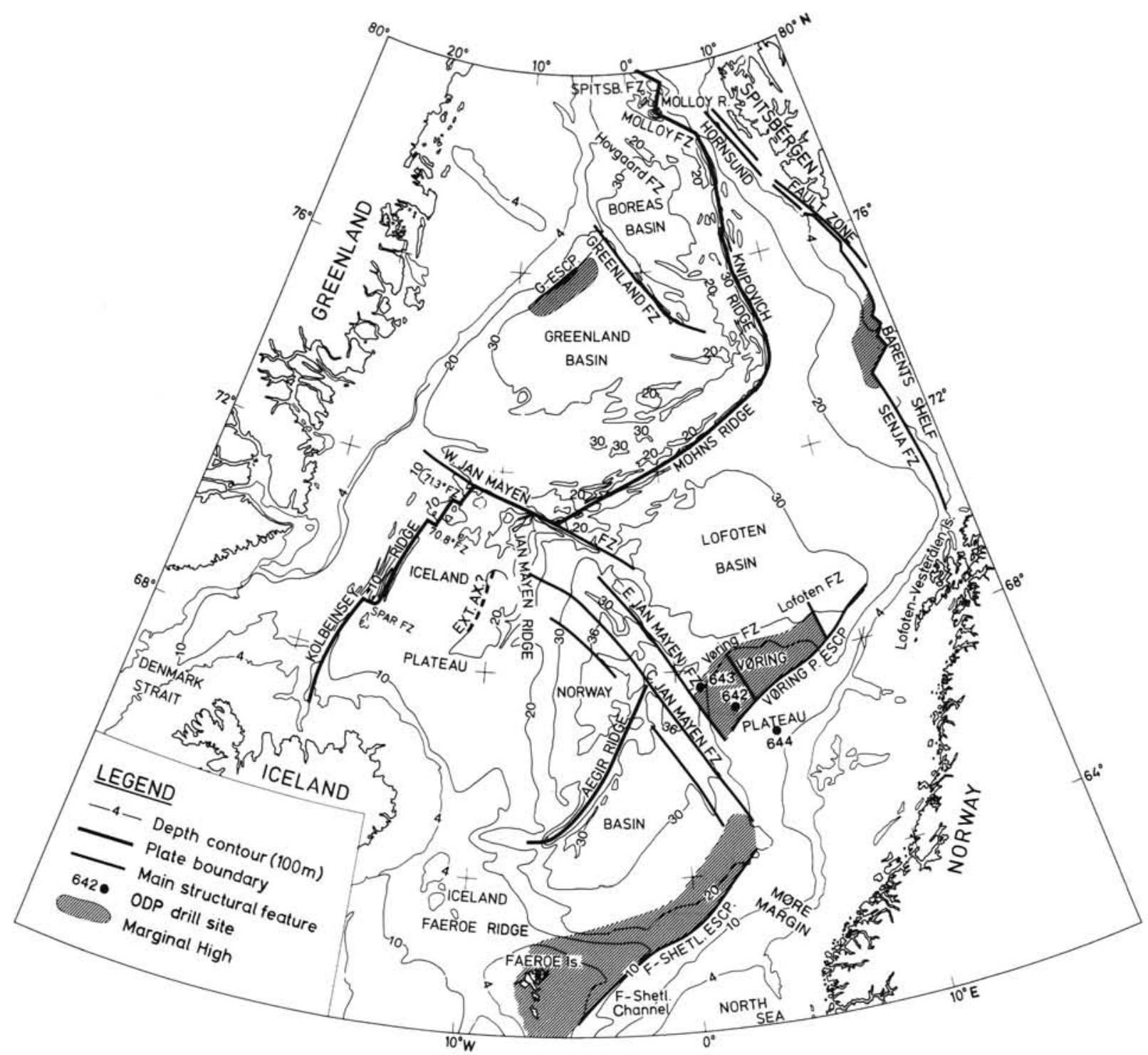

Figure 1. Main physiography and structural features of the Norwegian-Greenland Sea, based on Eldholm et al. (1989). Simplified bathymetry is based on Perry et al. (1980).

mentary basins resting on continental crust on the shelf and slope. Nearer the margin, the province is recognized by a change in the seismic character of the oceanic basement from an irregular, highly diffracting surface to a smooth, opaque horizon. In most places the smooth acoustic basement, which appears contiguous with oceanic basement, also shallows with respect to the adjacent oceanic crust, forming a buried marginal high beneath the lower continental slope. Landward, the high terminates abruptly at escarpment-like features marking the outer boundary of the sedimentary basins. The oldest seafloor-spreading anomalies in the Norwegian-Greenland Sea (24B-23, Fig. 2) overlie both kinds of basement surface. Locally, sub-basement reflectors are observed beneath the smooth acoustic basement. Of these, the spectacular, large wedges of seaward-dipping reflectors are most easily recognized in the seismic record, and their nature and origin have received much attention. Less attention, however, has been given to other features in the same geological province. In our opinion, these seaward-dipping reflectors should be considered as one, albeit important and integral, unit of a distinct crustal province between typical oceanic crust and pre-Tertiary basins at the shelf and slope.
Physiographically and structurally, the Norwegian Margin is composed of three regions with the Vøring Margin as the central part (Eldholm et al., this volume), and Figure 1. The Vøring Plateau marginal high is particularly prominent, bounded landward by the Vøring Plateau Escarpment. To the south, the high is terminated by the Jan Mayen Fracture Zone system, which offsets the margin. The Faeroe-Shetland marginal high extends from the Faeroes to the central Jan Mayen Fracture Zone, but has a smaller relief and in general less clear seaward-dipping reflector sequences than at the Vøring Plateau. The Faeroe-Shetland Escarpment is also more complex and less prominent than its counterpart to the north (Talwani and Eldholm, 1972; Smythe et al., 1983; Talwani et al., 1983). The Lofoten-Vesterålen Margin north of the Vøring Plateau (Fig. 1) is characterized by a steep continental slope where opaque acoustic basement extends almost to the shelf edge. The basement is strongly block-faulted beneath the northernmost part of the slope. The marginal high is not observed north of the Vøring Plateau, although a gentle elevation in basement is observed west of the base of the slope where seaward-dipping reflectors have been described (Hinz and Weber, 1976; Eldholm et al., 1979; Sellevoll and Mokhtari, 1988). 


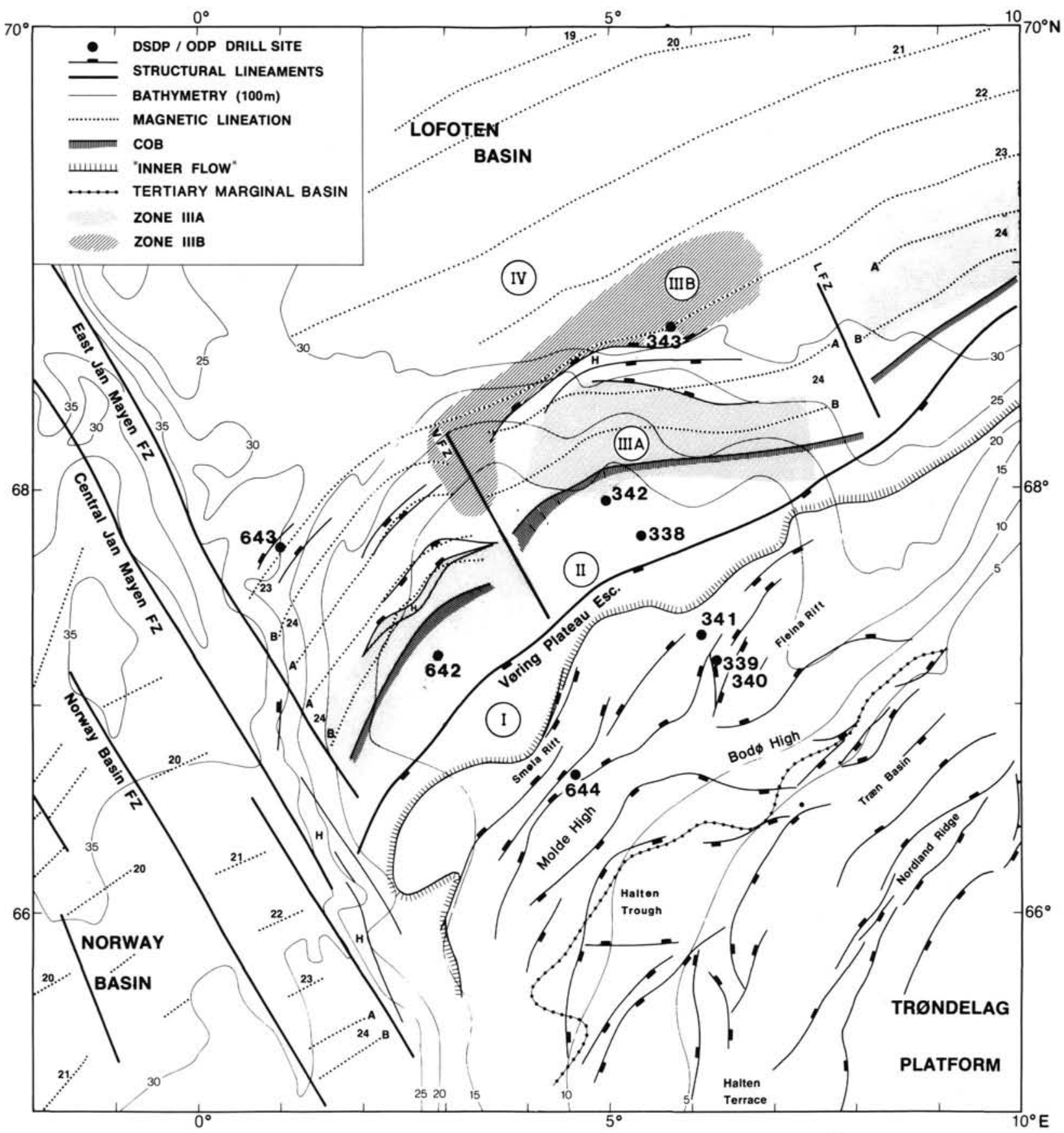

Figure 2. Main structural elements, seafloor spreading magnetic lineations (Hagevang et al., 1983; Skogseid and Eldholm, 1987; Skogseid and Eldholm, this volume), and ODP (642-644) and DSDP (338-343) drill sites at the Vøring Margin. Zones I-IV refer to the division of igneous units discussed in the text. H: structural high; VFZ: Vøring Fracture Zone; LFZ: Lofoten Fracture Zone; COB: Continent/ocean boundary.

A marginal high also exists beneath the lower slope south of the Greenland Fracture Zone (Eldholm and Windisch, 1974). Seaward-dipping reflectors have been reported beneath this high (Hinz et al., 1987) which is conjugate to the Lofoten-Vesterålen Margin. A similar setting exists beneath the eastern flank of the Jan Mayen Ridge (Skogseid and Eldholm, 1987). Finally, we note the existence of a marginal high at a rifted segment of the Barents Sea Margin (Fig. 1) (Myhre and Eldholm, 1988; Faleide et al., 1988).

The Deep Sea Drilling Project (DSDP) Leg 38 drilling at the Vøring Margin (Talwani, Udintsev et al., 1976) confirmed that the opaque acoustic basement reflector was basalt emplaced in a spreading type environment. Later multichannel seismic (MCS) profiles have, however, revealed complex structuring within the marginal high as well as in the adjacent Vøring Basin. The margin zonation in Figures 2 and 3 is based on characteristics of the acoustic basement and sub-basement reflectors in the MCS data (Hinz et al., 1982, 1984; Talwani et al., 1983, Skogseid and Eldholm, 1987). Zone IV represents typical oceanic basement; Zone III the wedges of seaward-dipping reflectors; Zone II a region of irregular sub-basement reflectors between the dipping wedge and the escarpment; and Zone I a strong, intrasedimen- 
tary volcanic reflector $10-40 \mathrm{~km}$ landward of the escarpment. Presently, the Vøring Margin is considered one of the outer continental margins best surveyed by MCS profiles (Skogseid and Eldholm, this volume). High-quality aeromagnetic (Hagevang et al., 1983) and velocity measurements (Mutter et al., 1984; Eldholm and Mutter, 1986; Mutter and Zehnder, 1988) have also been acquired. The geophysical data and the knowledge of the sub-surface geology of this particular margin have caused much speculation, resulting in different models for its evolution.

The understanding of the Vøring Margin has progressed in three phases. At first, attention was focused on the nature and evolution of the Vøring Plateau Escarpment and its relationship to the continent/ocean boundary. Then, the discovery of seaward-dipping reflectors led to intensified mapping by sophisticated seismic techniques and search for models to explain the observed sub-basement features. The recognition that dipping reflectors exist also at many other passive margins introduced the concept of a volcanic margin.

Initially, the Vøring Plateau Escarpment was interpreted as demarcating an abrupt change from continental to oceanic basement (Talwani and Eldholm, 1972; 1973). It was demonstrated that the escarpment, in addition to its indisputable seismic expression, marked changes in the gravity and magnetic fields and in the lateral velocity distribution. The observation of sub-basement structuring, particularly seaward-dipping reflectors (Hinz and Weber, 1976; Hinz and Schlüter, 1978; Talwani, 1978; Talwani et al., 1981) and the basaltic nature of reflector EE (Fig. 3) (Talwani, Udintsev et al., 1976) appeared to favor a volcanic origin of the high. However, a sedimentary origin has also been entertained. Hinz and Schlüter (1978) suggested the wedge contained either pyroclastic or pre-rift sediments, whereas Bally (1983) assumed sedimentary layers filled into a half-graben by a continentward dipping listric fault. Actually, a sedimentary wedge was still considered during the planning of Leg 104, having a strong impact on safety considerations.

Two competing kinds of emplacement models have been advocated for the dipping sequences at the Vøring Plateau. Ac- cording to Hinz (1981), the volcanic material was extruded over a thinned, contaminated continental crust in a subaerial to shallow-marine setting during the late rifting stage. In contrast, Mutter et al. (1982) invoked an igneous sequence formed subaerially during the earliest phase of seafloor spreading. They applied the model of subaerial crustal accretion developed for Iceland by Walker (1964) and Pálmason (1973). Noting that the dipping reflectors were located landward of anomaly 23 and their relationship with an opaque, smooth acoustic basement surface along the margins of the Norwegian-Greenland Sea, Eldholm et al. (1979) suggested that the dipping wedges reflect intense volcanic activity during early seafloor spreading, possibly associated with migration of the plate boundary. Such volcanism caused an overprint of the young oceanic crust, as well as the adjacent continental crust.

A band of low-frequency reflectors, bounded on top by $\mathrm{K}$, has been mapped at the base of the sub-basement sequence in Zone II and part of Zone III (Figs. 2 and 3), thus extending from the escarpment to the inner seaward-dipping wedge. Mutter et al. (1982) put the continent/ocean boundary at or close to the Vøring Plateau Escarpment, and interpret reflector $\mathrm{K}$ as a dike-lava transition within the oceanic crust. On the other hand, Hinz et al. $(1982,1984)$ place the continent/ocean boundary farther west, near the seaward edge of the lowermost part of the dipping reflectors, and reflector $\mathrm{K}$ is interpreted as an upper Mesozoic surface that existed prior to seafloor spreading. Smythe et al. (1983) have interpreted the Faeroe-Shetland Escarpment (Fig. 1) as a buried feather-edge of lower Eocene flood basalts without any relevance to the continent/ocean boundary and inferred that this was also the case for the Vøring Plateau Escarpment. Any model has to account for the magnetic lineations at the outer plateau (Fig. 2). Anomalies 24A and 24B overlie part of the seaward-dipping wedges (Hagevang et al., 1983), whereas the inner flows (Zone I, Figs. 2 and 3) are without a magnetic signature (Eldholm et al., 1979).

Variations of the Vøring Plateau emplacement models have been proposed for dipping reflector sequences at margins south of the Vøring Plateau. DSDP Leg 48 drilling at the West Rockall

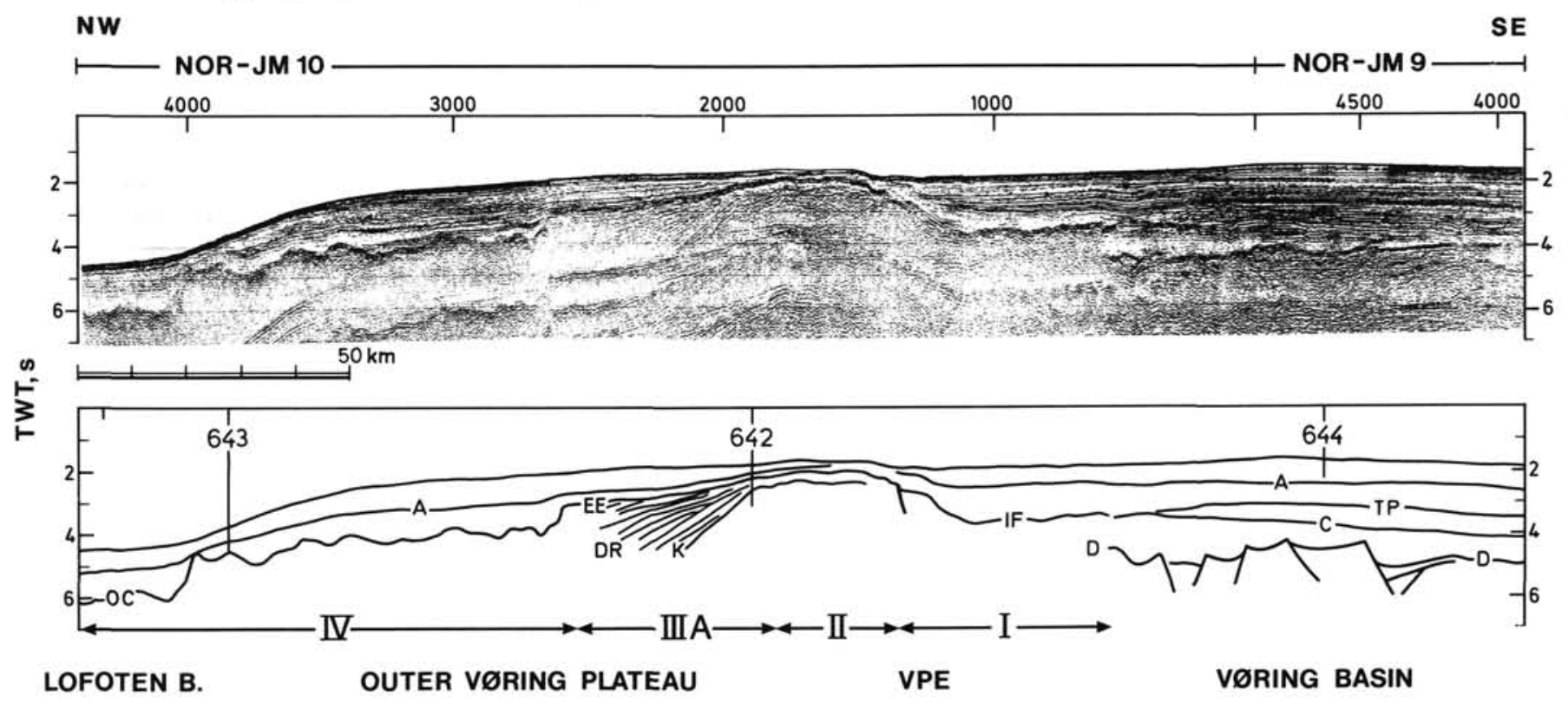

Figure 3. MCS profiles NOR-JM 9 and 10, recorded by the University of Oslo onboard Håkon Mosby in 1986, through all three Leg 104 drill sites. The section reveals the main geologic features of the Vøring Plateau shown by the simplified interpretation below. OC: oceanic crust; DR.: seawarddipping reflector sequence; K: reflector K; EE: top of lowermost Eocene flow series west of the Vøring Plateau Escarpment; IF: inner flows; A: lower Miocene unconformity. Seismic interpretation from Skogseid and Eldholm (this volume). A larger version of this figure is shown in the introductory chapter of this volume. 
Margin led Roberts et al. (1979) to suggest progradation of shallow-water and deltaic sediments interbedded with extrusives during the rifting stage. This hypothesis was modified after DSDP Leg 81 to an extrusive dipping sequence originating from dike intrusions throughout the region of stretching prior to spreading (Roberts et al., 1984b). At the Faeroe-Shetland marginal high, Smythe (1983) favors subaerial seafloor spreading with the early lavas flowing over continental crust, thus placing the continent/ocean boundary at the lower end of the oldest dipping reflector.

Since the presentation of the above models, new data have elucidated the relationship of the outer Vøring Basin and the Vøring marginal high during early Tertiary rifting and early seafloor spreading (Skogseid and Eldholm, this volume). However, except for Mutter (1984) and Skogseid and Eldholm (1987), little comprehensive seismic analysis has been published. In particular, Skogseid and Eldholm (1987) noted that reflector K terminated beneath the inner part of the main seaward-dipping wedge a distance landward of anomaly 24B. They argued that the entire sub-basement sequence above $\mathrm{K}$ was caused by subaerial seafloor spreading, and that the flow properties of the basaltic melt allowed the lava to flow over large areas of neighboring thinned continental crust. They located the continent/ocean boundary just west of the reflector $\mathrm{K}$ termination, below the innermost part of the seaward-dipping wedge (Fig. 2). A heavily intruded continental, or transitional, crust was inferred between the continent/ocean boundary and the Vøring Plateau Escarpment. This model was used during the preliminary interpretation of the Site 642 data (Eldholm et al., 1987).

\section{PRINCIPAL DRILLING RESULTS}

We now summarize DSDP and ODP drilling results that directly relate to the early margin history, particularly focusing on the composition, age, and depositional environments of the $\mathrm{Pa}$ leogene rocks.

\section{DSDP Leg 38}

Of six sites drilled on the Vøring Plateau Margin (Fig. 2), Sites 338,342 , and 343 were drilled to basement on the outer plateau, and the cores demonstrate a pronounced change in depositional setting during Paleogene times (Fig. 4). The oldest, terrigenous lower Eocene sediments contain decomposed basalt fragments throughout. The coarser components at Site 338 were interpreted by Caston (1976) in terms of a location closer to the sediment source and/or a higher energy environment. The basal sediments at Site 338 are compatible with a basaltic source being eroded until the uppermost early Eocene, most probably into the middle Eocene. Off the plateau at Site 343, the terrigenous sediment supply ceased abruptly near the end of the early Eocene, whereas it was delayed until the late Eocene at Site 338. Subsequently, the sediments reflect a change to hemipelagic and pelagic conditions with a dominance of biogenic silica-rich material.

The three basement sites recovered altered volcanic rocks that have been divided into two types based on petrochemistry. Site 338 yielded basalts similar to low-alkaline tholeiites whereas the basalts at Sites 342 and 343 were more alkaline (Kharin, 1976). A chemical affinity to the Faeroes plateau basalts has been noted by Ridley (1976), and Schilling (1976) suggests that the basalts reflect an initial Jan Mayen plume activity. The five basalt horizons with interbedded sediments sampled at Site 343 were interpreted as probable sills (Talwani, Udintsev et al., 1976). Dating by the K-Ar method has, however, produced ages that conflict both with the oldest overlying sediments (Fig. 4) and seafloor spreading anomalies. Ages of $46.6 \pm 2.5$, about 44, and $24.5 \pm$ 2.0 Ma were determined by Kharin et al. (1976) for Sites 338, 342 , and 343 , respectively. Talwani and Udintsev (1976) relate this discrepancy to the strong alteration of the basalts.

\section{ODP Leg 104 Sediments}

The sediment composition at Sites 642 and 643 is grossly similar to that of Leg 38. A thick sequence of hemipelagic and pelagic sediments rests on terrigenous material overlying volcanic basement. The pelagics are in turn covered by a glacial section (Fig. 5). It is appropriate to point out, however, that there is considerable relief in basement at the marginal high and that preglacial sediments thin, and might even be absent, over local highs, particularly at the northern plateau as shown by Site 342 (Fig. 4) and Skogseid and Eldholm (this volume).

The sediments at Site 642 have been divided into four lithological units (Eldholm, Thiede, Taylor, et al., 1987). The Miocene pelagics comprising Units II and III (Fig. 5) are dominated by biogenic siliceous muds and oozes. Carbonates appear in the late Miocene, culminating with almost pure pelagic nannofossil oozes in the early Pliocene. These data are compatible with a progressively subsiding Vøring Plateau since the early Miocene.

Lithological Unit IV (Fig. 5) is composed of muds and sandy muds, including a large component of volcanic ash. Abundant glaucony, repeated coarsening-upward beds, and bed thickness indiciate a proximal volcanic source, probably not more than 20-30 km away. The site is located on the outer flank of a basement high and the seismic sequence analysis supports this interpretation (Skogseid and Eldholm, this volume). Moreover, Unit IV reveals changing depositional conditions with time. The homogeneous, structureless, zeolite and glaucony rich muds in the lower part suggest fine-grained deposition in quiet bottom waters influenced by strong chemical alteration. The upper, coarser, well-stratified part reflects a greater input of primary clastic material and decreasing alteration. At the top of the unit there is a thin glauconite- and phosphate-rich sandstone marking the prominent lower Miocene unconformity in the seismic record (Fig. 3). This hardground probably formed over an extended time period under low deposition rates, and weak but effective currents in a quiet shelf to proximal-slope environment which received frequent input of pyroclastic material. Thus, the Unit IV/III transition marks a major hiatus over which the Vøring Plateau changed from a high-energy, shallow, terrigenous province to an open-water pelagic, biogenic-dominated depositional region.

At Site 643, which recovered a more complete pre-middle Miocene section, five lithological units have been identified (Eldholm, Thiede, Taylor et al., 1987) (Fig. 5). The pre-glacial Neogene section, Units IV-II, is again dominated by siliceous components with calcareous material arriving in the late Miocene (Unit II). Unit IV consists of monotonous mudstones with minor amounts of calcareous mudstones and nannofossil chalk. However, a major lithologic change occurs near the Unit IV-III transition. At about $300 \mathrm{mbsf}$, there is a very high degree of consolidation and complex diagenetic alteration causing compaction-lamination in most of Unit IV, as well as lithification and alteration of nannofossil oozes by diagenetic dissolution and recalcification. Unit V is dominated by zeolitic mudstones, most of which are compaction-laminated, and altered pyroclastic sediments reflecting open-water deposition, probably since the early-middle Eocene. A comparison of the lowermost lithological units at Sites 642 and 643 shows clear differences. For example, glauconite is only present at Site 642 , suggesting a much closer volcaniclastic source and different depositional bathymetries. These changing environments between the top of the plateau and the outer flank correspond to the DSDP sites farther north (Caston, 1976). Increasing amounts of altered volcanic ashes, reworked pyroclastic rocks, and thick welded and compacted pumicestones were recovered from the basal part of Unit V. The last two cores contained pebble to cobble-size basalt fragments and conglomerates of weathered and well-rounded basaltic and pyroclastic clasts in a crushed and weathered basal- 
338

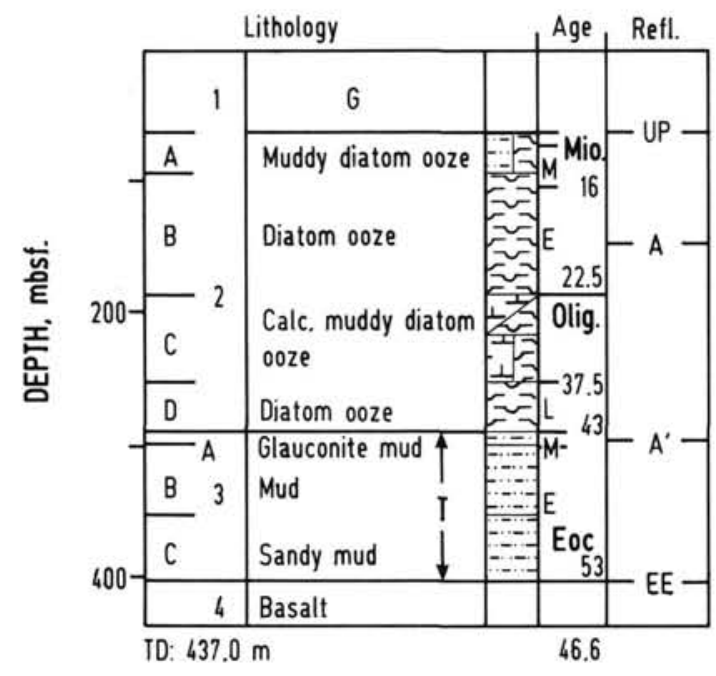

343

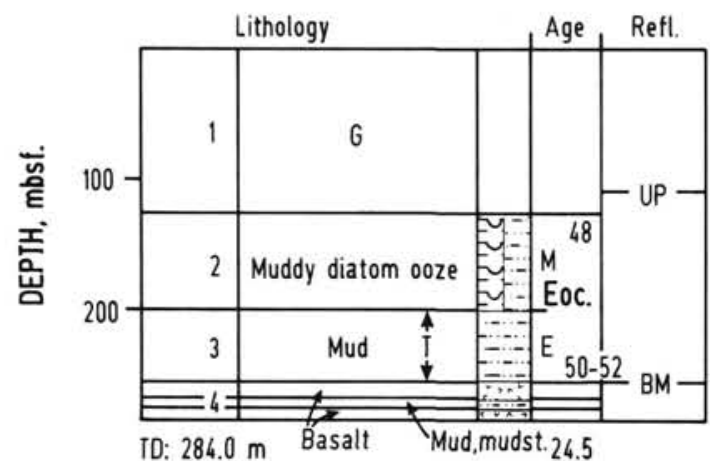

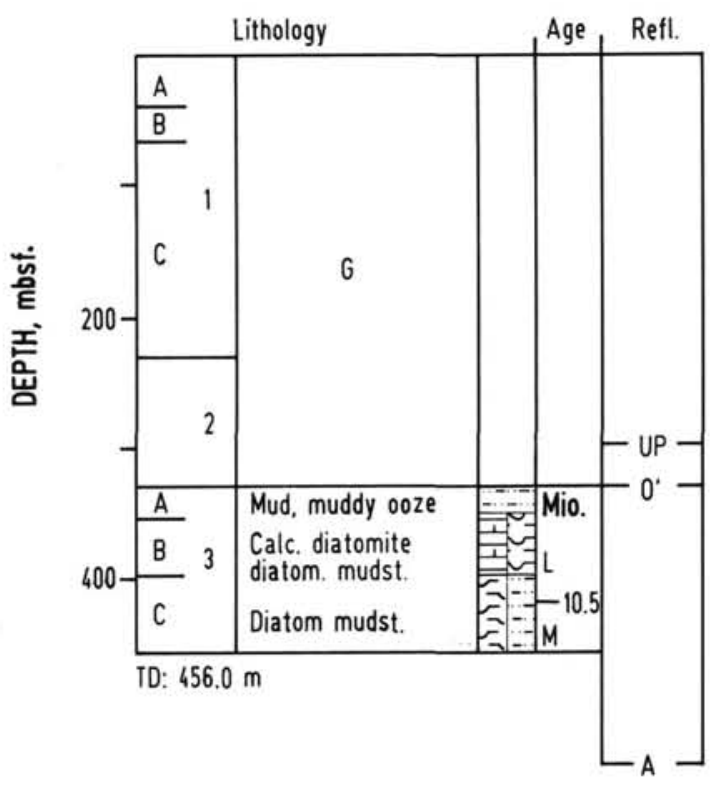

342

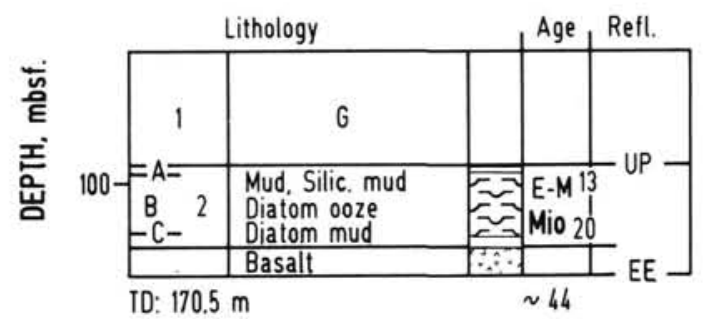

Figure 4. Summary of main DSDP Leg 38 results for the drilled preglacial section at the Vøring Plateau (Talwani, Udintsev et al., 1976; Schrader et al., 1976). Site locations are shown in Figure 2. G and T indicate glacial and terrigenous sediments, respectively. Seismic reflector levels from Skogseid and Eldholm (this volume). K-Ar ages for the basalts recovered near the total depth (TD) shown at the base of the diagrams (Kharin et al., 1976).

tic matrix. Similar lithologies have been reported in a lower Eocene turbidite sequence overlying basement at Site 343 (Talwani, Udintsev et al., 1976).

\section{ODP Leg 104 Basement Rocks}

Although Site 643 did not drill into basement, we infer from the vigorous sedimentary reworking in the lowermost $5 \mathrm{~m}$ of recovery, the basal lithologies and the analogy with Site 343, that the hole was terminated in sediments directly overlying basement. Fragments of pillow lavas and quenched flows have revealed N-MORB compositions, which are depleted in high fieldstrength elements compared with Site 642 upper series basalts (Eldholm, Thiede, Taylor et al., 1987). These data are consistent with an underlying oceanic crust.

Basalts were recovered near the bottom of Hole 642D at the level of reflector EE (Fig. 3). The site drilled through a volcanic sequence consisting of 138 lava flows, 5 dikes and 61 interbedded volcaniclastic sediment layers (Fig. 6). The most exciting finding was that a $13.2-\mathrm{m}$ thick sediment bed below $1086.8 \mathrm{mbsf}$ marks a prominent geological boundary between two volcanic series. The sediments are estuarine quartz and mica-rich volcaniclastics with minor epiclastic sandy mudstones. The upper and lower series are distinctive in the textural, structural, physical, mineralogical, and chemical characteristics of the flows, as well as in the composition of the interbedded volcaniclastic sediments. The entire section has been deposited in a terrestrial environment. The large negative reflection coefficient calculated from physical property data, the vertical seismic profiling (VSP) experiment and seismic correlation (Eldholm, Thiede, Taylor et al., 1987; Skogseid and Eldholm, this volume), suggest that the boundary between the two volcanic series is associated with reflector $\mathrm{K}$ in seismic records (Fig. 3). It also appears that the lower series flows form a seismic low-velocity zone below K.

A number of upper series flows have reddened tops. Pillows and hyaloclastites are not observed, but some flows and sediments indicate deposition in shallow water (Fig. 6). Thus subaerial and near coastal environments are suggested during the emplacement of this series. Occurrences of native copper in many flows have been related to subaerial weathering and subsequent interaction between sea water and lava (LeHuray, this volume). 


\section{2}

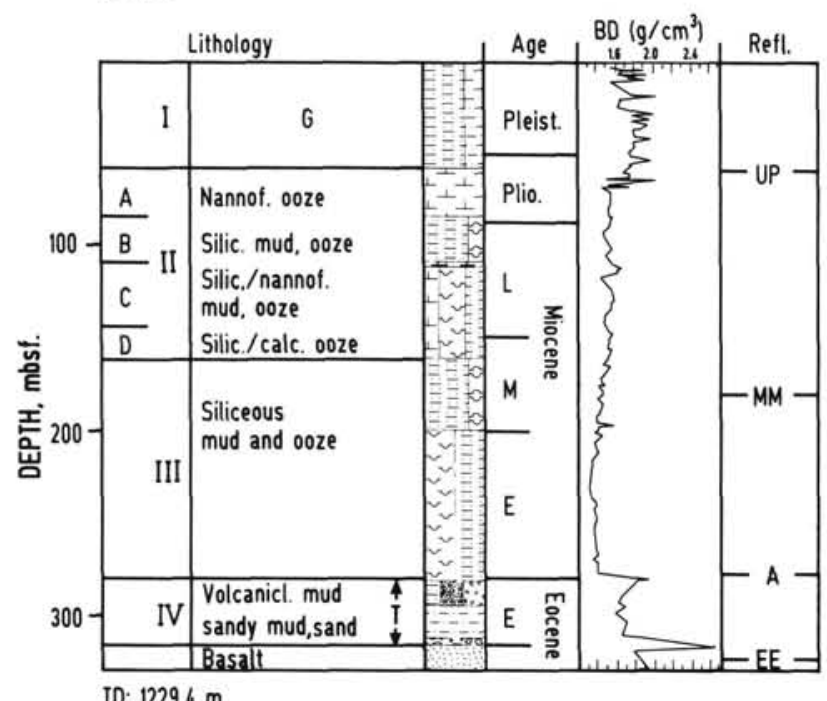

\section{3}

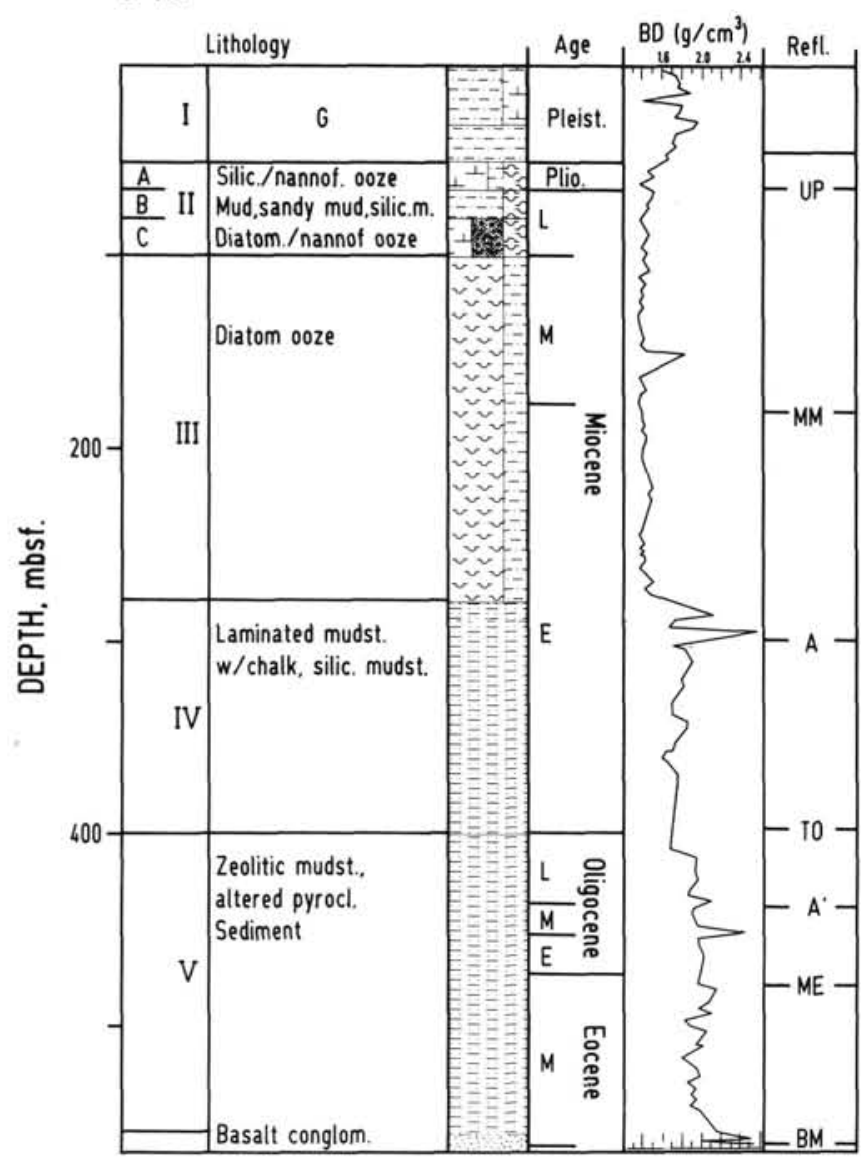

TD: $565.2 \mathrm{~m}$

Figure 5. Summary of main ODP Leg 104 Site 642 and 643 results for the drilled preglacial section (Eldholm, Thiede, Taylor, et al., 1987; Goll, this volume). Site locations are shown in Figure 2. G and T indicate glacial and terrigenous sediments, respectively. Seismic reflector levels from Skogseid and Eldholm (this volume). BD: bulk density.
The 138 flows in the upper series have been classified as groups of fine- and medium-grained basalt varieties differing in crystallinity, internal flow fabric, physical properties, and thickness. Logging to the base of the series considerably improved delineation of flow boundaries and allows distinction between the two flow groups that cannot be separated chemically. Viereck et al. (this volume) propose that the medium-grained type reflects small, proximal, and poorly flowing pahoehoe lavas, whereas the fine-grained type represents larger, distal, and more viscous lava flows. The entire series exhibits a low-K, low-Ti transitional mid-oceanic tholeiite (T-MORB) composition and has been divided into seven units (Fig. 6). The lowermost flows are the least fractionated and are derived from the largest degree of partial melting. The entire series is interpreted as originating from a primary, strongly depleted mantle source that was later LIL-element enriched. The upper series has clear chemical affinities to the Paleogene plateau basalts within the North Atlantic Volcanic Province (NAVP) (Thompson et al., 1986; Upton, 1988), as well as to Holocene magmas from the Mohns and Knipovich ridges (Neumann and Schilling, 1984) and parts of the Reykjanes Ridge (Schilling et al., 1983).

The 53 interbedded basaltic vitric tuffs constitute about $4 \%$ of the upper series. The sediments are strongly altered, with thicker and more frequent beds above $740 \mathrm{mbsf}$. Chemically, the upper layers are similar to the lower Eocene tuffs of the Balder Formation in the North Sea (Knox and Morton, 1983, 1988). The structuring within the pyroclastic material is not primary, but indicative of reworking by shallow marine and/or fluvial, possibly aeolian, activity. Although Plinian-type eruptions appear to be the only mechanism for generating the widespread tuff deposits, Viereck et al. (1988) favor an additional local source within a distance of $100 \mathrm{~km}$ as the eruptive origin of a major part of the sediments in the upper series.

There is no clear base of the lower series in the seismic record (Fig. 3). If we associate it with the change in seismic character at the termination of a band of low-frequency reflectors, the thickness is probably not less than $350-400 \mathrm{~m}$. Thus, Site 642 only drilled $142.6 \mathrm{~m}$ into the upper part of the lower series. The drilled section consists of 18 extrusive lava flows, 7 sediment layers and 2 dikes. The sediments comprise close to $20 \%$ of the section, a magnitude greater than in the upper series. The division of the lower series into three flow groups (Parson et al., this volume) is supported by isotope geochemistry (Taylor and Morton, this volume). Group B (Fig. 6) consists of 13 perlitic to variolitic dacite flows. The existence of cordierite in several flows probably reflects partial fusion of continental crust. The flow chemistry further suggests that the source magma derived from partial melting of continental material in a shallow magma chamber (Taylor and Morton, this volume). Trace-element analysis by Viereck et al. (1988) seems to be compatible with melting of Caledonian metasedimentary rocks, while lower crustal granulite facies do not fit the data. Group B is underlain by five microcrystalline basaltic andesite flows divided into groups A1 and A2 (Fig. 6). Parson et al. (this volume) interpret the most basic group, A2, as a mixture of group B rocks with a MORBtype tholeiitic melt. Finally, group Al, found in one flow only, is chemically intermediate between groups B and A2. The two dikes in the lower series are of the same tholeiitic composition as the upper series, but originate from a more depleted mantle source with slight evidence of crustal contamination. Apparently, they postdate the lower series, but were intruded prior to the main feeder dikes for the upper series.

The lower series sediments, which include a 9-m thick ignimbrite unit, display structures compatible with fluvial or shallowwater marine deposition. Although altered glass shards and pumice dominate, terrigenous components such as mica and quartz occur throughout. Pervasive alteration and cementation might re- 


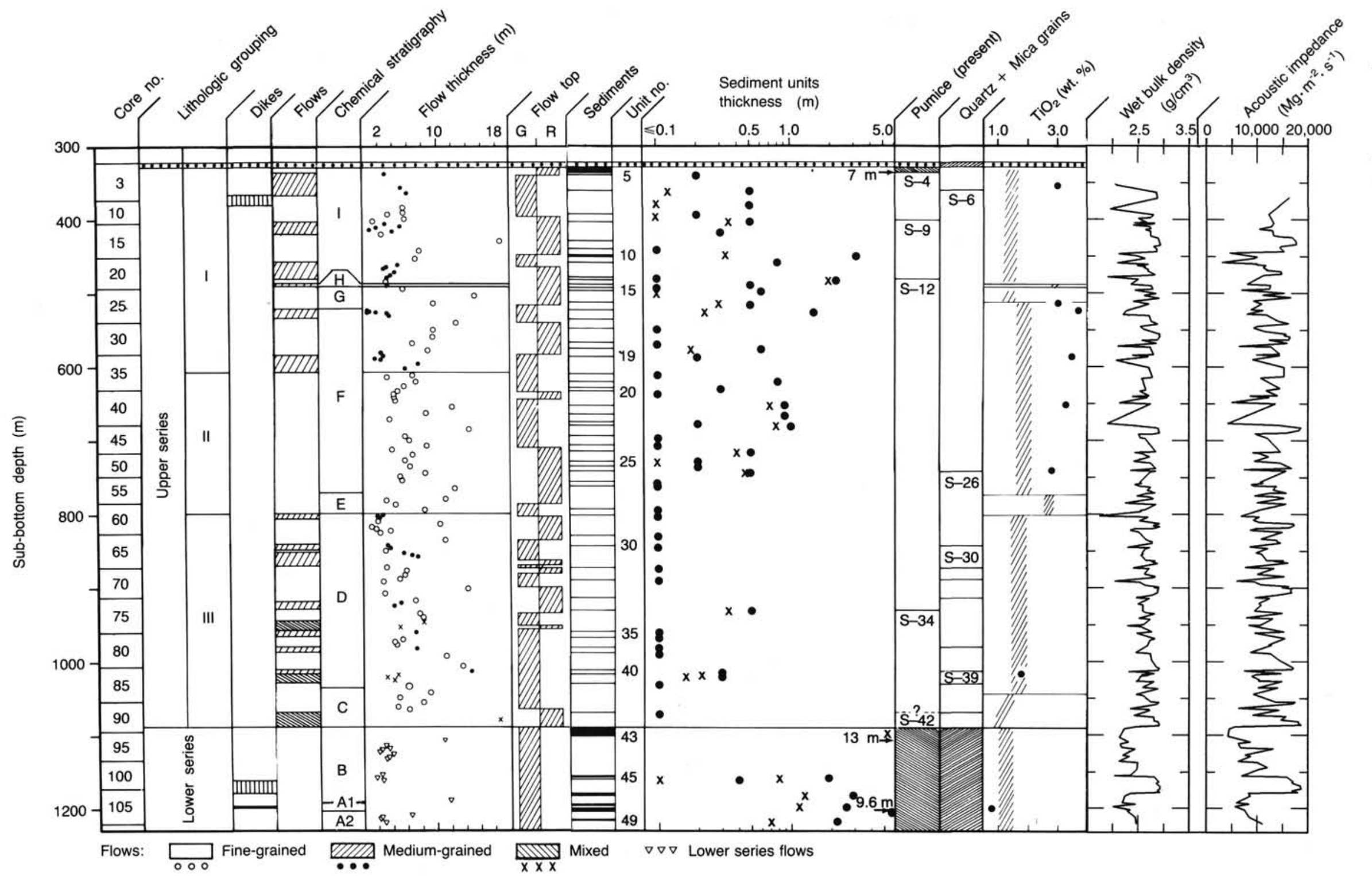

Figure 6. Lithostratigraphy, chemical stratigraphy, and petrography of lavas and sediments of the Site 642 volcanic sequence, updated from Eldholm, Thiede, Taylor, et al. (1987). Chemical stratigraphy from Parson et al. (this volume) and Viereck et al. (this volume). Flow top: $\mathrm{G}=$ gray, $\mathrm{R}=$ reddened. Thickness of sediment layers: $\mathrm{x}=$ recovered thickness, dots $=$ estimated thickness. $\mathrm{TiO}_{2}$ weight $(\%)$ : Hatching $=$ flows, dots $=$ sediments. Bulk density and acoustic impedance values from shipboard physical property measurements. 
flect hydrothermal temperatures from 80 to $90^{\circ} \mathrm{C}$, causing problems in characterizing the sediments chemically. However, Viereck et al. (1988) deduce a dacitic composition, suggesting that they are partly reworked volcaniclastic material from Plinian eruptions within $10 \mathrm{~km}$ of the site.

\section{EARLY TERTIARY RIFT-DRIFT EVENTS}

The volcanic rocks and interbedded sediments recovered at Site 642 document two characteristic, but different, volcanic series emplaced during breakup between Norway and Greenland in the early Tertiary. In addition, the seismic data attest to contemporaneous igneous and volcanic activity in the adjacent Vøring Basin. Similar features extend along strike of the margin on both sides of the escarpment (Hinz et al., 1984; Mutter et al., 1984; Skogseid and Eldholm, 1987, this volume). Therefore, we illustrate the rift-drift events by a type section across the ODP sites at the southern plateau, which we consider representative of the entire outer Vøring Margin (Fig. 7).

\section{Upper and Lower Series}

The top of the flows, reflector EE (Fig. 3), has been penetrated at ODP Site 642 and DSDP Sites 338 and 342 (Figs. 4-6). The seismic correlation with Site 642 results shows that the bit drilled through the entire innermost wedge of the main seawarddipping reflector sequence at the southern plateau. Our analysis shows that the bit penetrated reflector $\mathrm{K}$, which is associated with the pronounced geological and physical changes in the flows on either side of the thick tuffaceous unit below $1086.8 \mathrm{mbsf}$ (Fig. 6).

The uppermost part of a dipping reflector sequence drilled at the West Rockall Margin (Roberts, Schnitker et al., 1984), revealed a volcanic sequence similar to the upper series at Site 642. Thus, we believe Site 642 confirms that seaward-dipping reflectors observed at outer margins in the North Atlantic* originate from constructions of tholeiitic primarily subaerial flow basalts and interbedded sediments. Furthermore, the seismic continuity between Zones III and II (Fig. 3) suggests that the upper series basalts are not restricted to the seaward-dipping wedges but continue, bounded by reflectors $\mathrm{EE}$ and $\mathrm{K}$, from the apex of the dipping wedge east to the escarpment. This is an important observation because it indicates that the seaward-dipping seismic pattern is largely a post-constructional feature.

The composition of the flows and dikes of the lower series (Parson et al., this volume) and their age (Fig. 8) show that the dacites represent a stage of margin evolution preceding the emplacement of the upper series. Several aspects of the lower series have been both surprising and enigmatic. In view of the proposed evolutionary models, it was not expected that another and different extrusive lava sequence existed below the dipping reflectors. It is important, however, that the poor flow properties of the more acidic lavas imply a feeder system close to Site 642. Moreover, the more pervasive, thicker interbedded sediments in the lower series reflect different depositional environments, such as lower relative elevation and less frequent flow extrusion. The lack of data to determine its dimensions makes additional predictions difficult.

Although alkaline volcanics have been drilled at the top of a seaward-dipping reflector off southwest Africa (Austin and Uchupi, 1982; Gerrard and Smith, 1983), peraluminous dacites had not been reported at a passive margin or within NAVP prior to Leg 104. Since Leg 104, results from a well in the notorthern Rockall Trough have become available, revealing volcanic rocks

*The term North Atlantic is here applied to the area from Charlie-Gibbs Fracture Zone to $80^{\circ} \mathrm{N}$. strikingly similar to the lower series at Site 642 (Morton et al., 1988a). Below a sequence of Holocene to upper Paleocene sediments, the well was drilled through about $700 \mathrm{~m}$ of extrusive basalts before penetrating $356 \mathrm{~m}$ into dacites. Note the 350 - to 400-m minimum thickness estimated for the corresponding lavas at the Vøring Plateau. The Rockall Trough lavas show three different lithologies. The uppermost basalts are olivine tholeiites, with picritic and alkalic tendencies interpreted as intraplate compositions. The main basalts are also olivine tholeiites, but with a composition quite similar to normal mid-ocean ridge basalt. According to Morton et al. (1988a), the lower, homogeneous cordierite-phyric dacites originate from melting at depth of argillaceous, possibly also arenaceous, rocks. $\mathrm{K}-\mathrm{Ar}$ dating gives ages in the range 51-58 Ma, averaging $55 \mathrm{Ma}$, without significant differences between the basalts and dacites. Recently, peraluminous rocks have been identified also landward of the southern Faeroe-Shetland Escarpment (A. Morton, pers. comm.). Despite the evolutionary complexity of these regions, we believe the similarity in timing and igneous succession suggests a common mode of evolution during late rifting.

\section{Outer Vøring Basin Igneous Activity}

Prior to breakup, the crust at the incipient Vøring Margin, which had previously been structured and thinned, again came under tension. The initial rifting was accompanied by relative uplift and erosion of the outer Vøring Basin, listric normal faulting in the Smøla and Fleina rifts (Figs. 2 and 7), and igneous activity. Actually, the base Tertiary horizon might be considered a rift unconformity in the outer basin. Skogseid and Eldholm (this volume) document that the early Tertiary extension and igneous activity did not affect the entire Vøring Basin, but is restricted to a 100 - to $150-\mathrm{km}$ wide region east of the Vøring Plateau Escarpment, the Tertiary Marginal Basin (Fig. 2).

Skogseid and Eldholm (this volume) further identified several igneous and volcanic features which they related to the igneous rocks at the Vøring marginal high (Fig. 7). These include: sills or low-angle dikes in the Cretaceous sediments; a sill-flow complex topped by the inner flows (Fig. 3) within a 10- to $40-\mathrm{km}$ wide zone adjacent to the escarpment (Zone I, Figs. 2 and 3); the lower Eocene ash marker, reflector TP; and a number of small, local craters or fissure vents at the level of the ash marker. Toward the escarpment, the sills appear at progressively shallower depths, approaching the landward edge of the inner flows.

\section{Timing}

Under the premise that the intrusive and extrusive igneous activity on either side of the Vøring Plateau Escarpment is part of an evolutionary succession leading toward normal seafloor spreading, we evaluate the relative and absolute time frame of the events. However, comparison of previous work in the North Atlantic, particularly within the NAVP, suffers from the use of a variety of time scales. For consistency, we have here applied the Cenozoic geochronology of Berggren et al. (1985) throughout, realizing that there is still room for improvement in the early Tertiary. For example, Haq et al. (1987) list magnetic anomalies 23-26 as 3-4 m.y. younger than Berggren et al. (1985).

Igneous activity associated with the initial rifting in the western Vøring Basin starts with sills and/or low-angle dikes in Cretaceous sediments migrating up and west with time toward the eastern edge of the inner flows (Fig. 7). The sills cut listric fault planes, but are never observed above the ash marker, reflector TP (Skogseid and Eldholm, this volume). The inner flows are in turn overlying the base Tertiary rift unconformity, so the emplacement of these extrusives took place in Paleocene and earliest Eocene.

Reflector TP is tied to sediments in the North Sea and at the margin off Norway which contain a record of early Tertiary vol- 


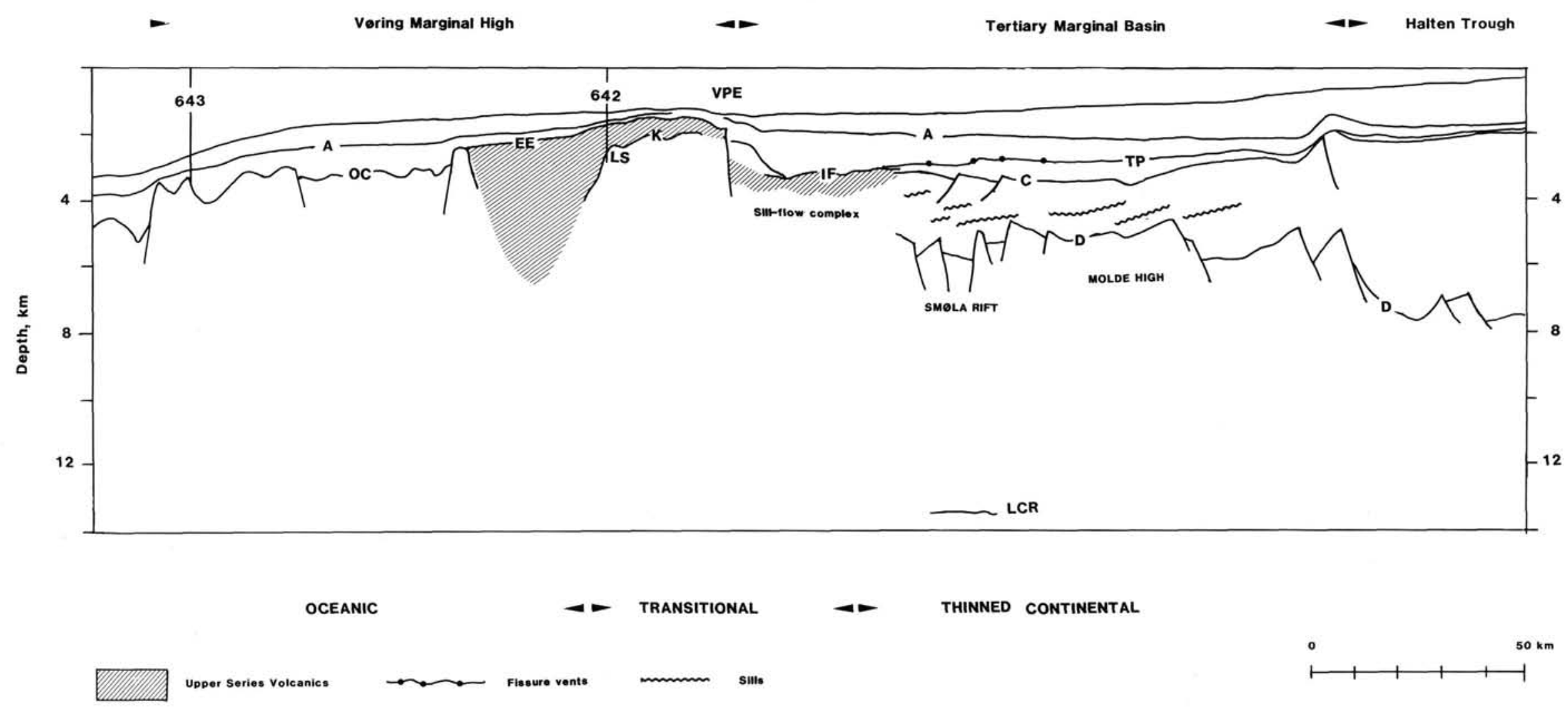

Figure 7. Schematic type section across the outer Vøring Margin showing the various early Tertiary igenous and volcanic units, main structural features (Skogseid and Eldholm, 1987, this volume) and crustal types. Depth conversion based on velocities from Mutter et al., (1984), Eldholm and Mutter (1986), and Eldholm, Thiede, Taylor, et al. (1987). A: lower Miocene; TP: lowermost Eocene (ash marker); IF: inner flows; EE: lower Eocene flows; K: reflector K; C: base Tertiary; D: base Cretaceous; LCR: lower crustal reflector; US: upper series volcanics; LS: lower series volcanics; OC: oceanic crust; VPE: Vøring Plateau Escarpment. 
$\begin{array}{lllll}\text { A } & \text { B } & \text { C } & \text { D } & \text { E }\end{array}$

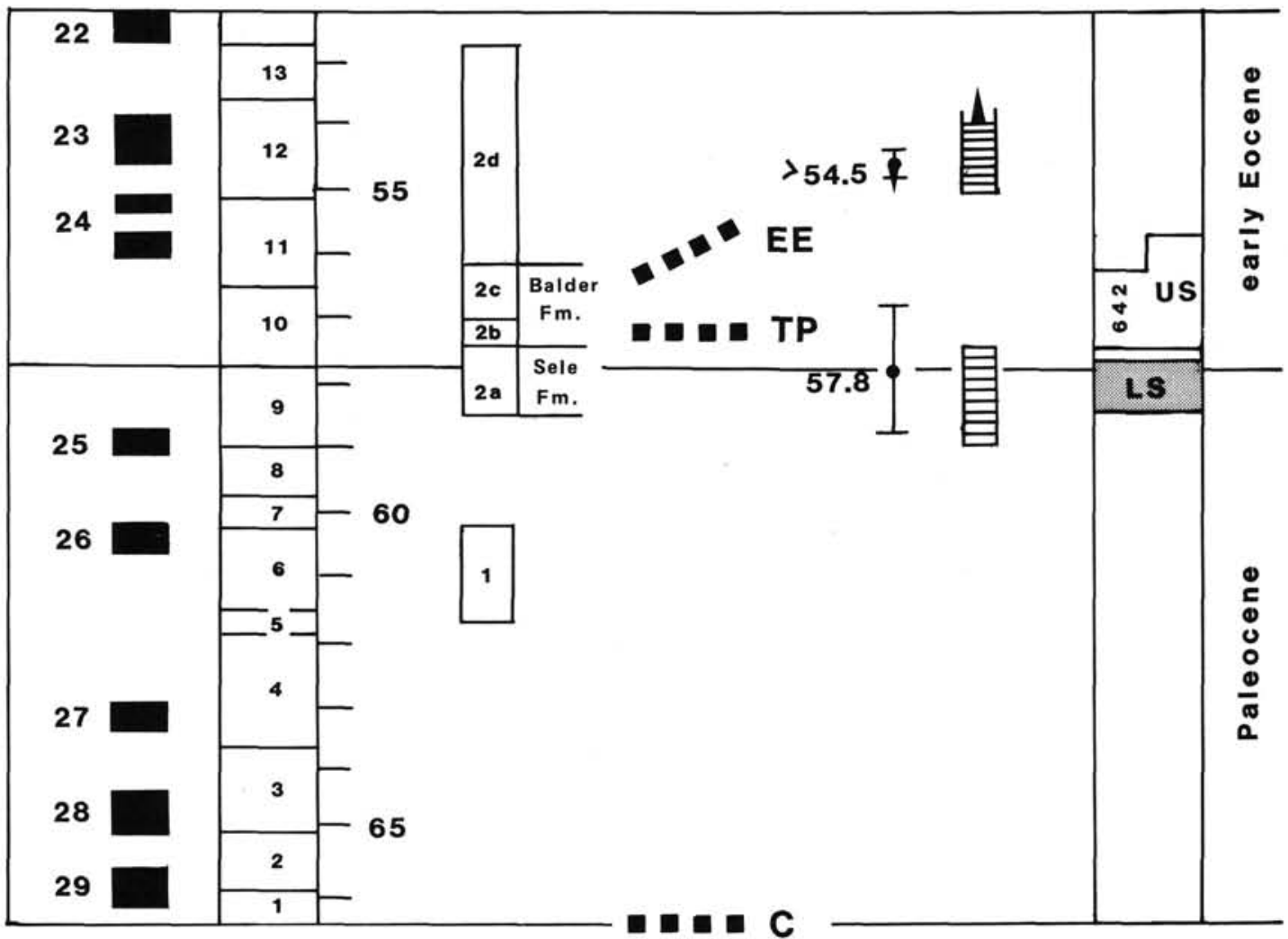

Figure 8. Age relationships for the early Tertiary rift-drift events at the Vøring Plateau. A: Magnetic polarity intervals (black $=$ normal polarity), nannoplankton zones and ages $(\mathrm{Ma})$ (Berggren et al., 1985). B: Phases of pyroclastic activity in the Faeroe-Greenland province and equivalent central North Sea formations (Knox and Morton, 1988). C: Seismic horizons EE (top of the time-transgressive lower Eocene flow basalts, TP (lowermost Eocene tuff marker) and C (base Tertiary) (Skogseid and Eldholm, this volume). D Left: Rb-Sr ages from upper and lower series flow basalts (LeHuray and Johnson, this volume). Note that the upper series age of $54.5 \pm 0.2 \mathrm{Ma}$ is an upper limit. D Right: Biostratigraphic ages from lower series interbedded sediments (Boulter and Manum, this volume) and sediments overlying the top of the flows (Schrader et al., 1976; Manum et al., this volume). E: Proposed time periods for the emplacement of the lower (LS) and upper series (US).

canism (Jacqué and Thouvenin, 1975; Malm et al., 1983; Knox and Morton, 1983; Knox, 1984). A recent summary by Knox and Morton (1988) documents several phases of pyroclastic activity, primarily associated with ashfalls from explosive volcanism. The pyroclastic record is composed of two main units, of which the earliest (Phase 1, Fig. 8) is of mixed basaltic to silicic composition. The later phase is divided into four subphases. Graded ash layers, ranging in composition from basaltic to silicic within the laminated mudstones of the North Sea Sele Formation, comprise the lower subphase (2a) which correlates with nannoplankton Zones NP9 and NP10. The most prominent pyroclastic unit is a series of closely spaced tholeiitic ash layers constituting subphase $2 \mathrm{~b}$ of NP10 age. Well preserved, numerous ash layers within indurated laminated mudstones of the lower Balder Formation produce the regionally recognized ash or tuff marker, reflector TP, in the seismic record. Finally, the two youngest, i.e., NP10-NP13, subphases consist of thin, infrequent ash layers of both basaltic and intermediate composition.

The correlation of subphase $2 \mathrm{~b}$ ashes and reflector TP yields an earliest Eocene age for the seismic marker, corresponding to Chron 24.2R (Fig. 8). A reversed magnetic polarity for the ashes has been reported by Hailwood and Knox (1988). Deposition of the ash marker also constrains the upper age for the emplacement of sills and low-angle dikes in the Vøring Basin to the lowermost Balder Formation in the North Sea. The distribution of intrusives across the margin is, however, compatible with igneous activity over a long time-span, but because of its relationship with the rifting process we propose the onset of the Tertiary as a lower bound for the intrusions. A similar, perhaps even more spectacular, sill complex is observed in the outer Møre Basin south of the East Jan Mayen Fracture Zone (Gatliff et al., 1984; A. Myhre, pers. comm., 1988) and in the Faeroe-Shetland trough (Ridd, 1983). Most of the sills are within Upper Cretaceous sediments (Gibb et al., 1986), although Gatliff et al. (1984) document sills in the Danian (NP1-NP4). Several commercial drill holes have penetrated the Faeroe-Shetland sill complex and K-Ar dating has yielded ages from 55 to $72 \mathrm{Ma}$ (Hitchen and Ritchie, 1987). These are considered uncertain by Gibb and Kanaris-Sotiriou (1988), who suggest a late Paleocene and younger time of emplacement, and a post-Paleocene age for the youngest sills. In view of the compelling similarity with the Møre Margin, we propose that the intrusive activity in the Vøring Basin was initiated in the middle Paleocene, increasing in intensity toward breakup in the earliest Eocene.

Reflector TP is contiguous with the eastern edge of the inner flows over most of the outer Vøring Basin but onlaps the flows in the southern part (Fig. 7). Thus, the inner flow horizon at the top of the sill-flow complex next to the escarpment is stratigraphically older than the ash marker. However, the separation in time is probably small, and the diachronous nature of the in- 
ner flows, offlapping to the west, indicates that the western area of inner flows might be time-equivalent with reflector TP.

Site 642 provides additional time constraints for the emplacement of the upper and lower series. The interbedded volcaniclastic sediments contain some fossils, mainly diatoms, silicoflagellates, dinoflagellate cysts, and pollen. Most of these are few in number, poorly preserved, and represent long-ranging species, the exception being abundant pollen and dinoflagellates in the lower series. Preliminary shipboard work indicated a late middle Eocene age for the top $450 \mathrm{~m}$ of the upper series, and a late early to late middle Eocene age for the interbedded sediments below (Eldholm, Thiede, Taylor et al., 1987). Subsequently, Manum et al. (this volume) and Boulter and Manum (this volume) redated the altered volcaniclastic sediments on top of the upper series (Fig. 5), as of early Eocene age, not younger than NP12. This is consistent with the oldest marine microfossilbearing sediments at Sites 338 and 343 belonging to Zone NPI2 (Schrader et al., 1976). Boulter and Manum (this volume) placed the lower series sediments within Zones NP9 and lowermost NP10, 57.5 to $59.0 \mathrm{Ma}$ (Fig.8).

LeHuray and Johnson (this volume) determined $\mathrm{Rb}-\mathrm{Sr}$ ages of $54.5 \pm 0.2$ and $57.8 \pm 1.0 \mathrm{Ma}$ for the top of the upper series and the lower series, respectively (Fig. 8), while Taylor and Morton (this volume) present a Rb-Sr age of $63 \pm 19 \mathrm{Ma}$ for the lower series. The $54.5-\mathrm{Ma}$ age is from celadonite, a late alteration product, and is thought to represent the foundering of the flow rather than time of emplacement, thus yielding a minimum age for the extrusion of the uppermost flows.

The entire upper series acquired its remanent magnetism during a period of reversed polarity, and the inclination record indicates an extremely fast extrusion rate, possibly a magnitude higher than in Iceland (Schoenharting and Abrahamsen, this volume). There is also a dramatic change to low magnetic intensity at the boundary between the two volcanic series. After removing a strong magnetic overprint caused by the dikes, Schoenharting and Abrahamsen (this volume) interpret the main part of the lower series, from 1113 to $1194 \mathrm{mbsf}$, as being magnetized during conditions of normal magnetic polarity. Nevertheless, the low intensity and complexity of the remanent field argue for caution in dealing with the polarities of the lower series. The thermomagnetic characteristics of basalts recovered during DSDP Leg 38 (Fig. 4) are indicative of subaerial conditions. A positive polarity was measured at Site 343 below anomaly $23 \mathrm{~N}$, whereas Sites 338 and 342 between the escarpment and anomaly 24B (Fig. 2) gave positive and negative polarities, respectively (Kent and Opdyke, 1978). In view of Site 642 results, the positive polarity at Site 338 is surprising, but the basalts were highly altered (Talwani, Udintsev et al., 1976).

The structural setting and location of Site 642 east of anomaly $24 \mathrm{~B}$ suggest that the drilled part of the dipping wedge was emplaced prior to $24 \mathrm{~B}$ during Chron $24.2 \mathrm{R}$. Correspondingly, we assign the main part of the lower series to Chron $25 \mathrm{~N}$. The reversed polarity near the base of the hole should originate from Chron 25R, which is older than the biostratigraphic ages from the same cores (Boulter and Manum, this volume). The discrepancy is related either to the uncertain lower series field behavior or to poor precision of the polarity timescale. We therefore tentatively correlate the lower series with pyroclastic subphase $2 \mathrm{a}$ and the Sele Formation (Knox and Morton, 1988), but note that the composition and thickness of the sediment layer between the two volcanic series might reflect a hiatus at this level (Fig. 8).

According to this scenario there is a direct relationship betwen volcanic events on either side of the Vøring Plateau Escarpment. We follow Knox and Morton (1988) and relate pyroclastic phase 1 (Fig. 8) to the final phase of British volcanism, preceding NAVP. Phase 2 , on the other hand, is associated with the early Tertiary opening of the Norwegian-Greenland Sea. The silicic components of the Sele Formation may be associated with the extrusion of the lower series. Furthermore, we suggest that the initial breakup and subsequent construction of the upper series led to deposition of subphase $2 \mathrm{~b}$ ashes, which are chemically similar to the upper series sediments (Viereck et al., 1988). This dates the breakup at Zone NP10, coeval with the lowermost Balder Formation, about 57.5 Ma (Fig. 8). Intensive volcanic activity at the time of breakup was also manifested by formation of fissure vents or local craters observed at the level of reflector TP (Fig. 7). Finally, the smaller magnitude and lessfrequent volcanism during subphases $2 \mathrm{c}$ and $2 \mathrm{~d}$ (Fig. 8) reflect waning of the intense breakup volcanism and a change to submarine generation of oceanic crust.

\section{North Atlantic Volcanic Province}

The NAVP includes the lower Tertiary igneous rocks of the North Atlantic borderlands that were emplaced prior to, or during, the breakup of Eurasia and Greenland (Noe-Nygaard, 1974; Upton, 1988). The province is a broad volcanic zone from Great Britain across the Faeroes and East Greenland to Baffin Bay, hence being a "transverse" feature with respect to the North Atlantic Ocean. Along this zone, active subaerial volcanism has continued to the present documented by Iceland being part of the shallow, aseismic Greenland-Scotland Ridge. A hotspot, lasting for 60 m.y., is most often invoked to maintain this activity. Recently, discoveries of huge buried igneous complexes along the outer margins of the Tertiary ocean has defined another, longitudinal, element of the NAVP from $55^{\circ}$ to $75^{\circ} \mathrm{N}$ (Fig. 9), along which subaerial volcanism was only active for about 3 $\mathrm{Ma}$. The age and volcanic nature of these complexes make them an integral part of NAVP, but they might reflect diverse crustmantle conditions which contribute to the variety of rock assemblages within NAVP. Presently, the relationship of NAVP to the opening of the North Atlantic is generally accepted, but there is still no consensus as to the nature, relationship, and timing of various tectonic and volcanic events. Therefore, we summarize key information from regions of NAVP that are adjacent to the continental margin (Figs. 9, 10).

\section{Faeroe Islands}

The Faeroes consist of subaerial lower Tertiary tholeiitic lavas at least $5.5 \mathrm{~km}$ thick (Waagstein, 1988). The basaltic lavas have been divided into a lower, middle, and upper series (Fig. 10). The lower series consists of more than $3 \mathrm{~km}$ of near-aphyric or aphyric tholeiitic flows relatively low in $\mathrm{TiO}_{2}$ and thin tuffaceous sediments, reflecting continuous volcanic activity. The oldest lavas have subsided at least $2.2 \mathrm{~km}$ (Hald and Waagstein, 1984). A $10-\mathrm{m}$ thick coal-bearing clay layer marks a quiet interval at the top of the series. The middle series was initiated by explosive volcanism, producing a sequence of tuffs and agglomerates grading into a 1.4-km thick sequence of thin olivine-phyric followed by plagioclase-phyric flows with only few and thin interbedded sediments. Continued volcanism built up the more than $0.9-\mathrm{km}$ thick upper series, characterized by thicker flows, similar to the lavas below, but often separated by tuffs (Hald and Waagstein, 1983). There is an upward progression from olivine tholeiites to tholeiites, both high in $\mathrm{Ti}$, in the lower part of the middle series. On the other hand, its upper part and the entire upper series consist of MORB-like olivine tholeiites and tholeiites (Waagstein, 1988).

Radiometric dating, reviewed by Abrahamsen et al. (1984), shows a range of 53-59 Ma. The entire upper, middle, and most of the lower series show reversed magnetic polarity, whereas the exposed upper part of the lower series reveals a normal-reversednormal polarity record (Abrahamsen et al., 1984; Schoenharting and Abrahamsen, 1984). The normal intervals have been correlated to Chrons $23 \mathrm{~N}$ and $24 \mathrm{~N}$ by Abrahamsen et al. (1984), whereas Waagstein (1988) prefers Chrons $25 \mathrm{~N}$ and $26 \mathrm{~N}$. 


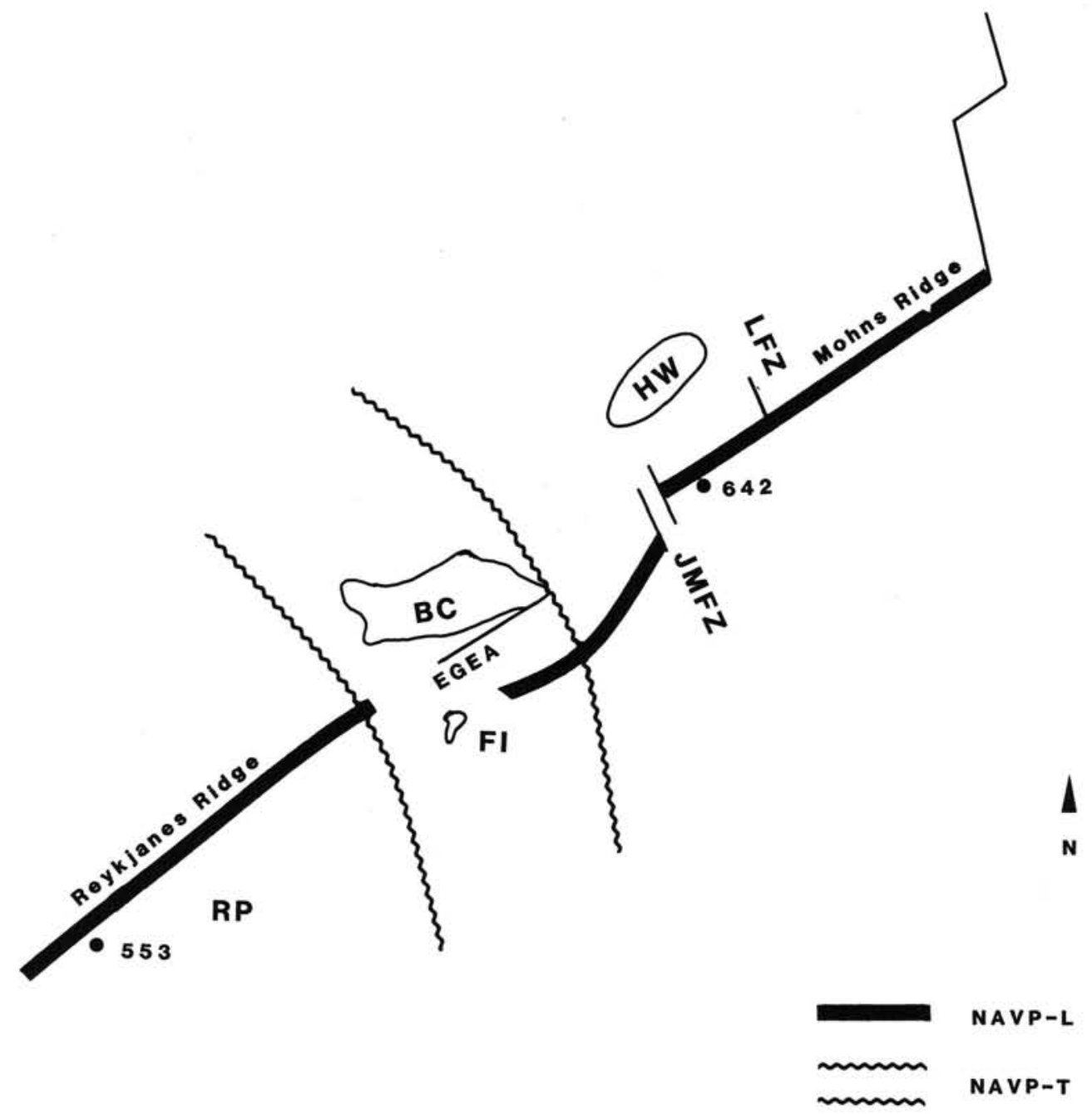

Figure 9. Sketch of the crustal configuration at the time of earliest Eocene breakup between Greenland and Eurasia including ODP Site 642 and DSDP Site 553, and the locations of pre-opening volcanism (RP: Rockall Plateau; FI: Faeroe Islands; BC: southern East Greenland Province; HW: northern East Greenland Province). The transverse (NAVP-T) and longitudinal (NAVP-L) parts of the North Atlantic Volcanic Province are also indicated. EGEA: East Greenland Extinct Axis (Larsen, 1988); JMFZ: Jan Mayen Fracture Zone; LFZ: Lofoten Fracture Zone.

The geochemical and isotope data point toward a change of source region between the eruption of the middle and upper series. According to Gariépy et al. (1983) continental contamination of the two lower series may reflect a change from melting of subcontinental lithosphere to oceanic asthenosphere. In addition, crustal contamination at the middle to upper series transition has been reported by Hald and Waagstein (1983). Waagstein (1988) favors an emplacement model in which the entire Faeroes lava pile predates seafloor spreading, with volcanism starting in the beginning of the Selandian (62 Ma) or earlier. The initial timing is supported by ashes west of the Shetland Islands which have been correlated with the lower series and Chron 26R (Morton et al., 1988b).

\section{Faeroe-Shetland Marginal High}

Despite the debate about the nature of the marginal high (Smythe et al., 1983; Talwani et al., 1983, 1984), little regional MCS documentation has been published. Smythe et al. (1983) suggested the marginal high is comprised of two basaltic sequences (Fig. 9) overlying pre-rift sediments. The top of the lower sequence, an analog with the inner flows at the Vøring
Plateau, was correlated with the ash marker, reflector TP, and traced across the escarpment. Thus, it corresponds to reflector $\mathrm{K}$ of Talwani et al. (1983), who contested the interpretation. Smythe et al. (1983) proposed that the two volcanic sequences were the equivalents of the lower and middle lava series in the Faeroes by correlating the ash marker with the coal-bearing sediments, an inference supported by geochemical data (Morton et al., 1988b). Waagstein (1988), on the other hand, rules out a common sediment source. The coal-bearing sediments contain a terrestrial microflora, dated as late Paleocene (Landenian) by Lund (1983). Boulter and Manum (this volume) state that the flora is similar to that of Site 642 lower series, and have narrowed the age range to Zone NP9.

Landward of the escarpment the Faeroe-Shetland sill complex becomes younger and shallower towards the edge of the inner flows, or lower volcanic sequence, which transgresses towards the northwest (Gibb and Kanaris-Sotiriou, 1988). In general, the ash marker is the lateral equivalent of the inner flows, although it locally onlaps the basalts as in the Vøring Basin. This suggests that reflector TP is slightly younger than, or about the same age as, the inner flows. Gibb et al. (1986) describe the 


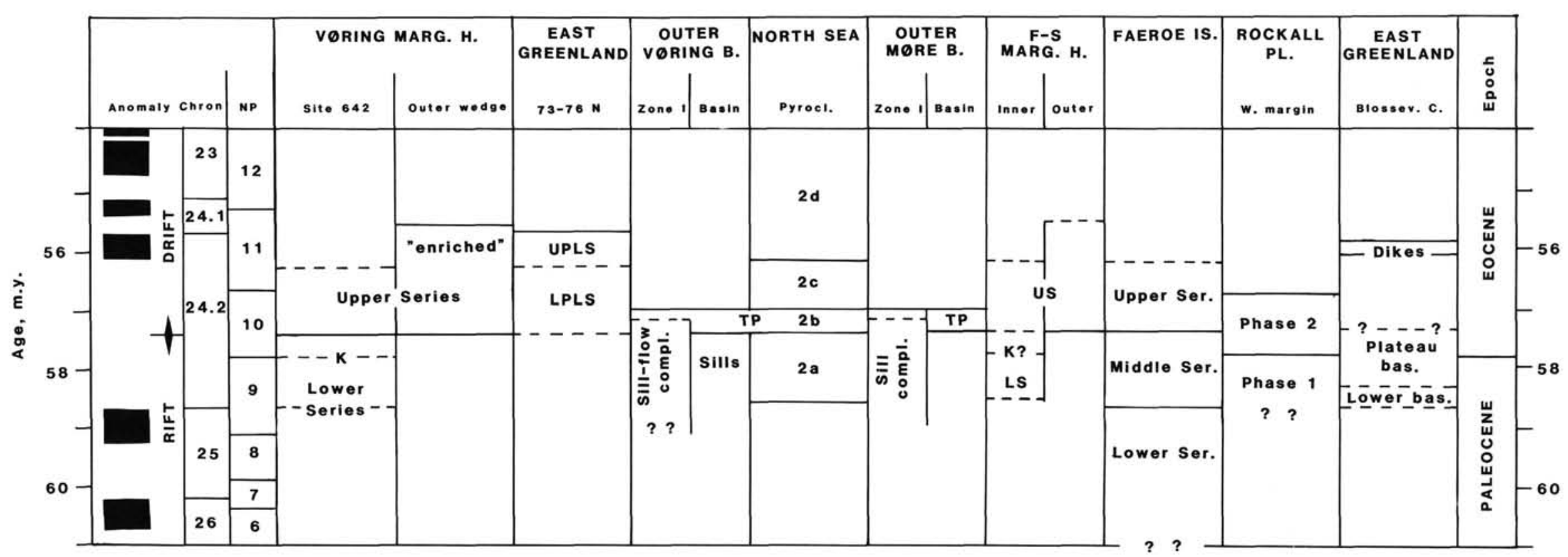

Figure 10. Correlation diagram of early Tertiary volcanic events in the North Atlantic Volcanic Province (NAVP) adjacent to the margins in the North Atlantic. The diagram refers to the Berggren et al. (1985) time scale and is based on the references described in the text. The timing, however, reflects the present interpretation. The positions of reflectors EE (top of upper series west of the Vøring Plateau Escarpment), TP (lowermost Eocene ash marker) and K (top of lower series) are also shown. 
sills as olivine tholeiites of oceanic affinity, which are strikingly similar to the olivine tholeiites of the Faeroes upper series, having little in common with those of the lower and middle series. In fact, the upper sills are chemically similar to transitional type MORB (Gibb and Kanaris-Sotiriou, 1988).

\section{East Greenland}

Large areas of tholeiitic lower Tertiary plateau basalts are exposed along the coast of East Greenland (Upton, 1988). These lavas may once have been much more extensive (Brooks, 1973), and extends locally onto the shelf (Larsen, 1984). The basalt province is divided into a northern region between $71^{\circ}$ and $76^{\circ}$ $\mathrm{N}$, where a number of smaller exposures exist along the coast and a southern region $\left(68^{\circ}-71^{\circ} \mathrm{N}\right)$ dominated by the large plateau basalt complex at the Blosseville Coast (Figs. 9, 10).

The thickest section in the northern province is about $800 \mathrm{~m}$, considered close to the maximum thickness that ever existed (Upton, 1988). The lavas constitute two series (Upton et al., 1980). The lower plateau lava series (LPLS) is characterized by subaerial, aphyric to sparsely phyric, flows probably erupted from fissure volcanoes east of the present coastline. Tholeiitic sills, mostly relating to LPLS, are abundant in adjacent Cretaceous and lower Tertiary sediments. The lower basalts are dominantly quartz tholeiites, relatively depleted in incompatible elements (Upton et al., 1984). The upper plateau lava series (UPLS) are thinner and reflect smaller eruption rates. These aphyric to porphyric flows are mainly enriched olivine tholeiites, with some alkali basalts. According to Upton et al. (1984), LPLS was emplaced through very thin continental crust during late rifting; whereas UPLS, feeding from a relatively deep mantle source, was extruded from a large shield volcano on the rift margin in the early spreading stage. There is no precise dating of the onset of volcanism; however, Hald (1978) describes a reversed magnetic polarity in LPLS, changing to normal at the base to lower part of the UPLS.

The Blosseville Coast flows thicken toward the coast, reaching a maximum of $3.5 \mathrm{~km}$ (Nielsen and Brooks, 1981). The lower lavas are a complex construction of variable composition, whereas the overlying huge plateau basalts consist of uniform Fe-Ti tholeiites (Brooks and Nielsen, 1982). The plateau basalts were fed by dikes paralleling the coast. At the end of the effusive period, another set of coast-parallel dike swarms, of composition similar to the plateau basalts but with clear MORB affinities, intruded the Precambrian basement and the young lavas between $69^{\circ} 45^{\prime}$ and $66^{\circ} 15^{\prime} \mathrm{N}$ with a probable offshore extension farther south (Larsen, 1978). The emplacement of the coastparallel dike swarm was accompanied by intense faulting, flexuring, and local intrusion of plutonic rocks presently reflected by a huge regional monoclinal flexure along the coast. It may be significant that this part of East Greenland lies along the transverse zone of the NAVP (Fig. 9). Larsen $(1978,1980)$ suggested that the coast-parallel dike swarm marks the initial plate separation, which is supported geochemically by Larsen and Watt (1985). The dikes generated some flows, preserved locally with interbedded sediments of upper Ypresian age (Soper and Costa, 1976). A probable positive polarity is indicated for the dike swarm (Larsen and Watt, 1985). The tholeiitic gabbro plutons yield a fission-track age of $54.6 \pm 1.7 \mathrm{Ma}$., corresponding to the 55-60 Ma K-Ar dates, of the basalts and dike swarms (Brooks and Gleadow, 1977). A re-evaluation of the K-Ar dating by Odin and Mitchell (1983) argues for a 50.0 \pm 1.4-Ma minimum age for the cessation of the volcanism.

Dinoflagellates near the base and in the upper part of the Blosseville flow sequence correlate with Zones NP9 and NP10, respectively, and the overlying sediments with the NP11/NP12 transition (Soper et al., 1976). A basal conglomerate is dated to base Sparnacian (Zones NP8/9) (Higgins and Soper, 1981). Thus, we arrive at a maximum time period from 55 to $59 \mathrm{Ma}$ for the effusive volcanism. Larsen and Watt (1985) note that the entire flow sequence is reversely magnetized, suggesting emplacement during the negative period between anomalies 24 and 25 . In view of the biostratigraphic dates, we assign the flows to Chron 24.2R (Fig. 10), limiting the extrusion period to a maximum of $2.5 \mathrm{Ma}$.

\section{West Rockall Margin}

The margin is underlain by shallow acoustic basement including seaward-dipping reflectors beneath the slope. The dipping reflectors extend along the entire margin, terminating seaward towards an outer basement high partly overlain by anomaly $24 \mathrm{~B}$. The dipping wedge appears to be the mirror image of a similar feature, but without the outer high, at the conjugate Greenland margin (Featherstone et al., 1977; Larsen, 1984).

DSDP Leg 48 and 81 drill holes established the sedimentary record above the basalts, and Site 553 penetrated $181.5 \mathrm{~m}$ of the uppermost dipping reflectors (Montadert, Roberts et al., 1979; Roberts, Schnitker et al., 1984). The dipping reflectors consist of subaerial, reversely magnetized, depleted tholeiitic flow basalt of MORB affinity, and minor interbedded sediments. $\mathrm{K}-\mathrm{Ar}$ dating of the lavas at Site 555 east of the dipping wedge gave ages of $53.5 \pm 1.9 \mathrm{Ma}$ for the basalts (MacIntyre and Hamilton, 1984), and fission track analysis of detrital apatite from the lower Tertiary sediments yields $56 \pm 3 \mathrm{Ma}$ (Duddy et al., 1984). We note that MacIntyre and Hamilton (1984) categorically state that there is no evidence of significant continental contamination, while $\mathrm{Pb}$ isotope studies of MORB-like magmas at Site 553 within the dipping wedge (Morton and Taylor, 1987) show contamination, probably from an ancient subcontinental lithospheric mantle (Merriman et al., 1988).

Two main volcanic phases are recognized at the margin (Fig. 9) (Montadert, Roberts et al., 1979; Morton and Keene, 1984), and the entire volcanism may have occurred within Chron 24.2R (Roberts et al., 1984a). The construction of the dipping reflector sequence by voluminous tholeiitic basalt flows of MORB affinity constitutes the initial phase, terminating near the Zone NP9/10 boundary.

The next phase is dominated by explosive volcanism, depositing tuffs of tholeiitic composition in intertidal marsh to shallow marine environments, ending abruptly at or close to the Zone NP 10/11 boundary.

\section{Regional Correlation}

In Figure 10 we suggest a temporal correlation of the main igneous and pyroclastic units in the various provinces discussed above based on the premise that the ash marker, reflector TP, represents a major volcanic event at breakup. We then used compositional, radiometric age, and magnetic polarity data for the igneous and pyroclastic rocks, as well as biostratigraphic ages of the interbeddded and bounding sediments, to construct the diagram. Because the reliable age constraints are few, Figure 10 is considered a first attempt at a regional correlation, but it documents several important features:

1. There is a temporal interrelationship between the various provinces.

2. The emplacement of the igneous rocks occurred prior, during and after breakup.

3. With the exception of the Faeroes, where the onset of volcanism is in question (Waagstein, 1988), the main volcanic activity along the margins of the incipient ocean spanned a period of not more than 3.5 m.y. However, the Faeroes also fit within this period if we accept that the lower series belongs to British volcanism (Merriman et al., 1988).

4. Both pre-opening and post-opening lavas were extruded over two successive short time periods, lasting not more than about 1.5 m.y. each. Such rapid outpouring of lava is not unique, 
however. For example, Courtillot et al. (1986) claim the Deccan flood basalts were erupted in less than $1 \mathrm{~m} . \mathrm{y}$.

At the Faeroe-Shetland marginal high, we have retained the main ideas of Smythe et al. (1983), and correlated the upper lavas with the upper series at the Vøring Plateau. We also imply a similar division in an inner and outer part of the marginal high as at the Vøring Plateau. Thus, the lower lavas of Smythe et al. (1983) might be the oldest part of the upper series, or represent a slightly older dacitic unit. Note that Figure 10 does not imply any distinction of crustal type under the inner parts of the marginal highs. On the other hand, we have not correlated the ash marker and the sediments at the middle-lower series boundary in the Faeroes. In fact, we interpret the marked change in flow character and mantle source near the base of the Faeroes upper series as an indicator of the actual breakup. The duration of the Faeroes volcanism hinges on the interpretion of the two normal polarity events in the lower series. We have followed Waagstein (1988) and Schoenharting and Abrahamsen (this volume), while Roberts et al. (1984a) have included the entire volcanic pile within Chron 24.2R.

The southern basalt province in East Greenland is normally interpreted to be emplaced during Chron 24.2R, and the subsequent coast-parallel dike swarm is associated with the breakup. Recognizing the normal magnetization of the dike swarm (Larsen and Watt, 1985), one cannot rule out the possibility that the extrusion continued for a longer period, terminating with the dike injection during Chron $24.2 \mathrm{~N}$ (Fig. 10). However, the compositional similarity of the plateau basalts and those at the Faeroes (middle/lower series) and the West Rockall Margin suggests that the main plateau basalt sequence was emplaced prior to breakup, possibly with continued waning eruptions toward anomaly $24 \mathrm{~B}$ time.

\section{Voring Plateau Emplacement Model}

If we consider the pre-opening location of the Vøring Plateau with respect to NAVP and the history of early Tertiary volcanism, the link between the Vøring Plateau and NAVP becomes obvious (Fig. 10). In developing an emplacement model, key data derive from physical, petrological, and geochemical properties of the basalts and interbedded, primarily volcaniclastic, sediments. It is well established that typically depleted MORB's are accreted in the setting of actively spreading mid-oceanic ridges as well as during rifting and initial seafloor spreading. However, there is much confusion as how to interpret various petrological and geochemical signals in terms of their position in time and space with respect to the rift-drift evolution at a passive margin. Much observed variability may, however, be attributed to mantle heterogeneity already established at the time of rifting (Richardson et al., 1984). In addition, the different evolution of the transverse and longitudinal parts of NAVP might be superimposed on the along-plate boundary inherent variablity in mantle conditions. Upton (1988) concludes a review of the NAVP with an excellent characterization by stating:

"Detailed stratigraphic and geochemical study of what were, until quite recently, regarded as monotonous sequences of tholeiitic plateau basalts, has demonstrated significant variability in time and place. The basalts have been shown to vary widely in terms of Mg-number, silica saturation, and incompatible element contents, with implications for significant variability in mantle source-rock compositions and the degree and conditions of source-rock melting, as well as for interaction with lithospheric wall-rocks at all levels, crystal-fractionation and magma mixing."

A main question is whether the tholeiitic extrusives forming the dipping reflector sequences and associated rock units are emplaced during the late stage of rifting or the initial period of seafloor spreading. In the first case, they reflect eruptions within the continental crust prior to breakup. In the second, they represent subaerial accretion of oceanic crust. Alternatively, they could develop during both stages, depending on the local setting. In this context the term breakup, or initial seafloor spreading, relates to the time when asthenospheric material has reached the surface, producing a growing crustal block that is entirely oceanic in composition. This block will acquire remanent magnetization reflecting the reversals of the Earth's field. At the initiation of spreading, there may still be feeders from the rising asthenospheric plume to the surface through the adjacent continental crust, but we believe this activity abates rapidly after breakup.

The emplacement model has to comply with the magnetic lineation pattern over the oldest oceanic crust. Few magnetic constraints exist south of the Norwegian-Greenland Sea where the seaward-dipping reflector sequences are located landward of anomaly 24B (Roberts et al., 1984b). At the Vøring Plateau, however, the southern dipping wedge terminates seaward between anomalies 24A-B and 24B (Chrons 24.1R-24.2N), and the main northern wedge between anomalies 24A and 24A-B (Chrons 24.1N-24.1R) (Fig. 2). Elsewhere in the Norwegian-Greenland Sea, well developed $24 \mathrm{~A}-\mathrm{B}$ anomalies overlie seaward-dipping reflectors in the Lofoten Basin (Eldholm et al., 1979), Greenland Basin (Hagevang et al., 1983; Hinz et al., 1987) and east of the Jan Mayen Ridge (Skogseid and Eldholm, 1987). This provides a key boundary condition, namely that at least part of the dipping sequence was extruded subsequent to breakup. Another boundary condition arrives from the basalts and sediments of the lower series, which clearly have originated in a continental environment.

In the following, we develop an emplacement concept for the two volcanic series at the Vøring Plateau in a pure symmetric rift setting, and return to the question of syn- and post-emplacement tectonism later. The concept depends on the flow properties of basaltic lava which allow it to move for long distances away from the feeder, whereas more acidic lavas flow for short distances only (Walker, 1973; Greeley, 1982). Thus, flows from intensive subaerial eruptions may cover both the newly formed oceanic crust as well as large areas of the adjacent continental crust. If we assume a central main injection zone from the onset of spreading, a dipping wedge may develop as schematically illustrated in Figure 11. The lower series is extruded in the late rifting stage, and breakup takes place within the dacites. Inititally, there is intense explosive volcanism, extrusion of large amounts of magma covering much of the neighboring, thinned continental crust. Gradually, the volcanism abates and changes to submarine spreading as the crust cools and contracts. This scenario is, in general, similar to the Vøring Plateau evolution model of Skogseid and Eldholm (1987), which combines key features of the dipping reflector models of Hinz et al. (1982), Mutter et al. (1982), and Smythe (1983).

Figure 11 also shows that the reversed polarities measured troughout the upper series at Site 642 only are representative of the inner wedge, and a unit of flows with normal polarity (Chron $24.2 \mathrm{~N}$ ) is expected in the outer wedge, a parameter testable by future drilling. An alternative model might include a sequence of tholeiitic basalts extruded over the lower series and adjacent sediments prior to breakup. In this case, a relatively shallow discontinuity would exist at the onset of the subaerial oceanic crust which is not observed in the seismic record. On the other hand, we cannot rule out a thin basal sequence of pre-breakup tholeiitic extrusives, or that breakup took place on the east flank of a mass of such basalts now centered on the conjugate margin.

These considerations lead toward the following history of evolution for the Vøring Margin volcanic and igneous activity (Fig. 12): 

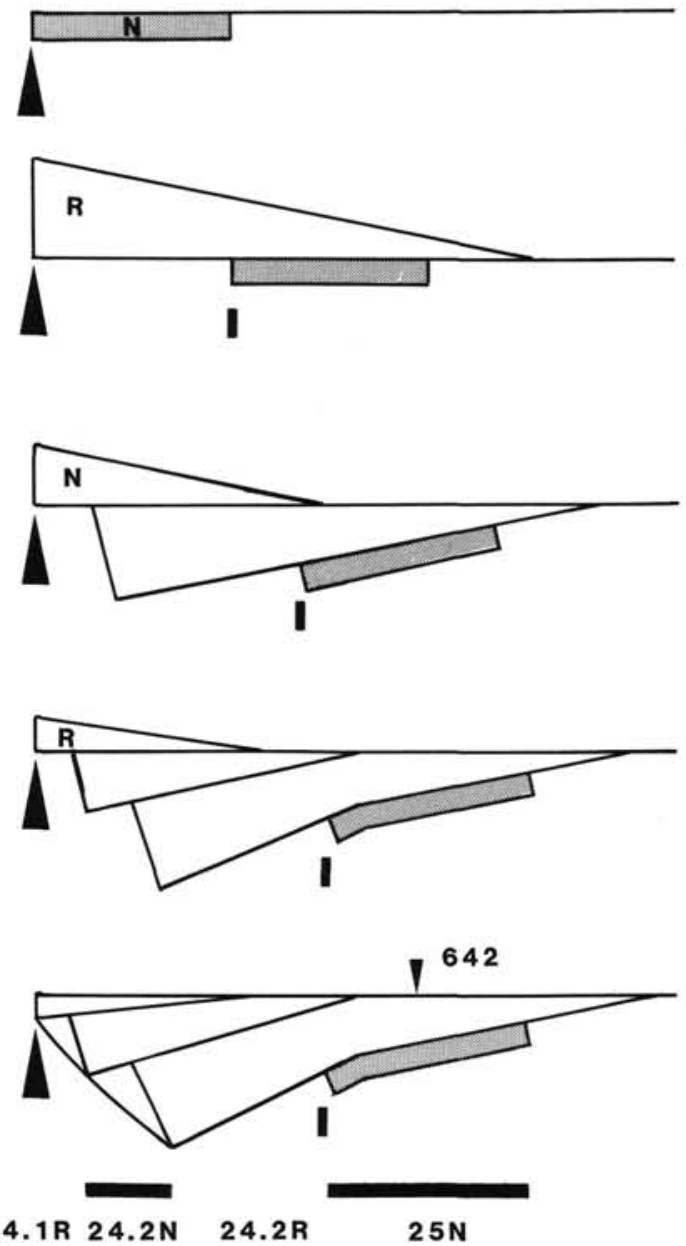

24.1R 24.2N 24.2R

$25 \mathrm{~N}$

I сов

Dacite flows

\section{Injection center}

Figure 11. Diagrammatic time slices showing the evolution and magnetization of the dipping reflector sequence and adjacent crust at the southern Vøring marginal high. Breakup takes place in thinned continental crust topped by normally magnetized $(\mathrm{N})$ dacitic flows, and the eruptive intensity abates with time. Effects of erosion and tectonism are not included and a continuous process of extrusion and subsidence will produce the gradual outer termination of the wedge indicated in the lower time slice. Diagrams are not to scale.

1. Paleocene. Crustal extension causes upward migration of the asthenosphere, uplift, partial melting and intrusions in the lower crust.

2. Late Paleocene. The asthenosphere plume invades the lower crust, maintaining the relative elevation of the nascent rift and the adjacent sedimentary basins and causing erosion of the rift and redeposition in the basins. The crustal extension develops normal listric faults in the Cretaceous shales on the flank of the inverted region. There are contemporaneous intrusions of sills and low-angle dikes on either side of the rift, gradually shallowing and merging towards the main rift axis as the plume ascends. Partial melting of thinned basement rocks and some sediments above the central plume creates a peraluminous dacitic magma, some of which is carried to the surface through dikes, emplacing the extrusives of the lower series during Chron $25 \mathrm{~N}$ (Fig. 11). The volcanism was relatively quiet and episodic, allowing deposition of the relatively thick interbedded sediments which constitute one fifth of the lower series. A volcanically quiet period, during which the thick sediments at the top of the series was deposited, ends this phase.

3. Earliest Eocene. The plume reaches the surface and initial oceanic crust is created during the middle part of Chron $24.2 \mathrm{R}$ (57-57.5 Ma). This phase is characterized by explosive, intense volcanism and high rates of magma extrusion, allowing deposition of only thin sediment layers between the flows. Subaerial, or Icelandic-type, generation of oceanic magma produces the subbasement reflectors in Zones II and III (Fig. 3), as well as the uppermost part of the sill-flow complex in Zone I (Skogseid and Eldholm, this volume). The high magma production corresponds to rapid spreading prior to anomaly 23 , when the spreading rate was about 2.5 times higher than at any later time (Eldholm et al., 1984). The ejecta from the breakup volcanism constitute the prominent regional ash marker horizon (Subphase 2b, Figs. 8 and 9), and the breakup is accompanied by minor volcanic disturbances expressed by fissure vents in the Vøring Basin.

4. Early Eocene. The intensive subaerial volcanism abates and the injection center submerges. However, part of the trailing marginal high still stands above sea level. Sporadic, but waning, local volcanism is reflected by the ashes within the lower Eocene sediments along the margin and in the North Sea (Subphase 2d, Fig. 8).

The Site 642 lower series dacites and interbedded sediments suggest the involvement of strongly attenuated continental crust in the last stage of rifting. An intriguing question is why dacites of this kind are not commonly found in similar rift environments elsewhere. We indicate two contributing factors. First, a major sedimentary basin is required to provide conditions for sediments or metasediments to be included in the melt. Second, the unconformity within the thick sediment layer separating the two series at the Vøring Plateau indicates a hiatus, probably associated with pre-breakup uplift and erosion.

The presumption of a heterogeneous mantle at the start of rifting is fully documented at Site 642 , and Viereck et al. (this volume) envisage three different mantle sources for the basaltic magmas. These are: a strongly depleted LREE source for the tholeiitic dikes in the lower series, a slightly depleted source for the transitional flows in the upper series, and a LREE enriched source for the upper series sediments. The latter might actually be located north of the Vøring Fracture Zone, having produced the enriched basalts recovered at DSDP Sites 342 and 343. A horizontal, possibly also vertical, dimension of the order of tens of kilometers is inferred for the different magma sources (Viereck et al., this volume).

At breakup, the basalts at the conjugate Greenland coast (HW, Fig. 9) were less than $150 \mathrm{~km}$ west of the continent-ocean boundary, but lavas are known to exist farther east beneath the inner shelf (Larsen, 1984). The corresponding position off Norway lies in the inner part of Tertiary Marginal Basin (Fig. 2), where flow basalts are absent indicating asymmetric rift volcanism. We note strong compositional affinities between the upper series at Site 642 and the lower plateau lava series (LPLS, Fig. 10) at Hold With Hope and Wollaston Foreland (Upton et al., 1984; Viereck et al., this volume). An equivalent of the upper plateau lava series (UPLS, Fig. 10) was not sampled at Site 642, but does exist in the form of enriched lavas drilled at Sites 342 and 343 (Schilling, 1976).

In view of the Site 642 results we have modified the emplacement model for the northern East Greenland basalts proposed by Upton et al. (1984). We suggest that the LPLS and its submarine extension, together with the Vøring Plateau upper series, were mainly emplaced after the time of breakup (Fig. 10). The fact that the coastal lavas overlie continental crust at large dis- 


\section{Early-Middle Paleocene}

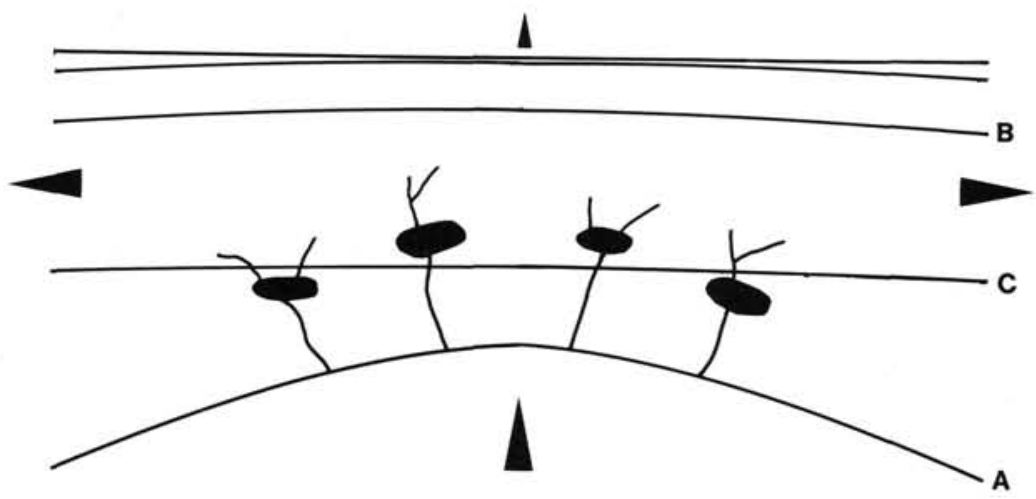

Late Paleocene
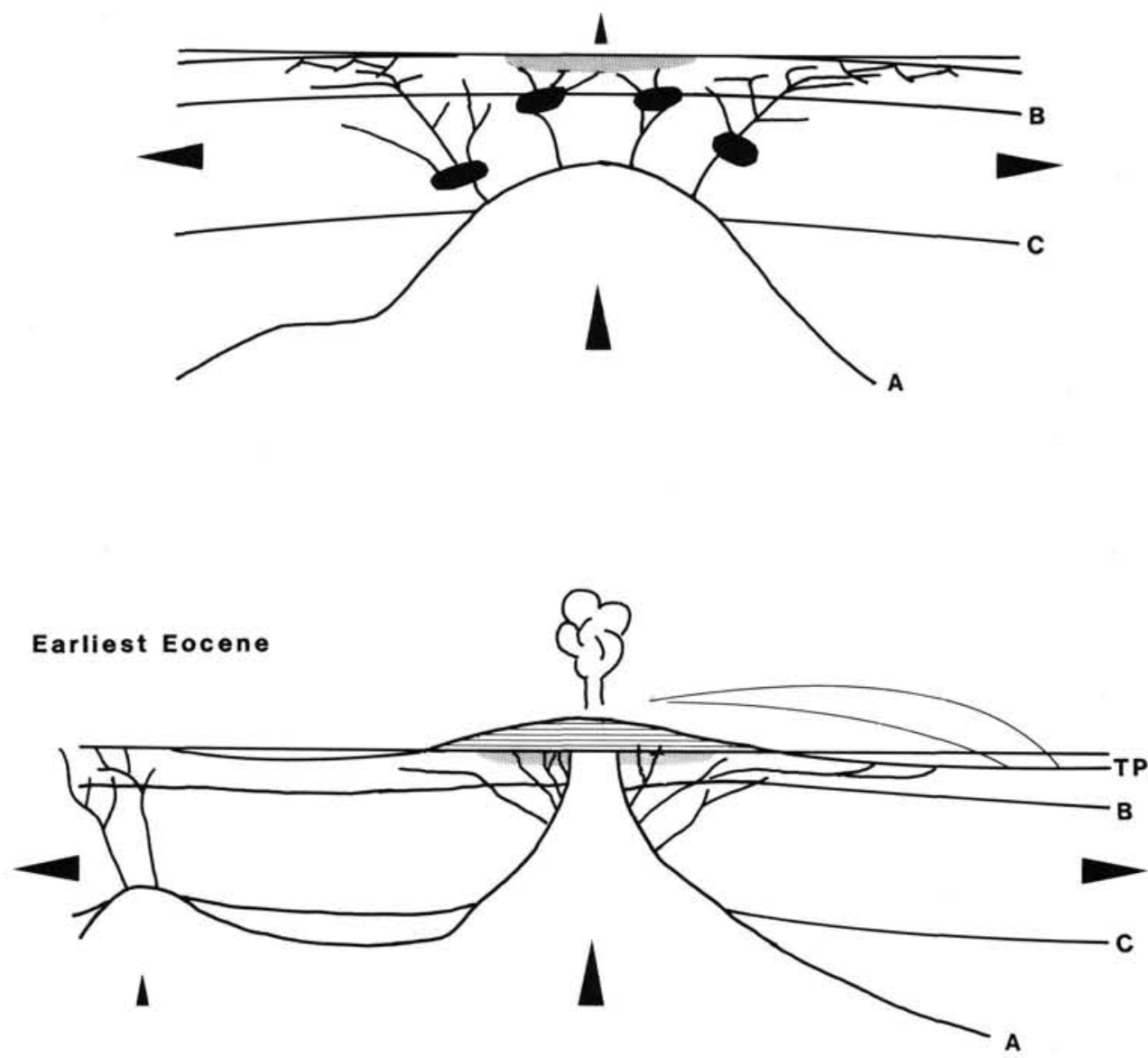

Figure 12. Evolutionary sketch of the main phases during emplacement of the Vøring Plateau and conjugate East Greenland early Tertiary magmatic units. TP: lowermost Eocene ash marker; B: Pre-opening crystalline basement; C: base of the crust; A: base lithosphere. Sketches not to scale. 
tances from the continent/ocean boundary reflect two feeder systems. A main zone of injection in the east, and short-lived conduits in the west. The latter may follow pre-existing, probably Late Jurassic-Early Cretaceous, faults feeding the Greenland basalts through thinned continental crust (Fig. 12). An analog structural setting exists in the southern Red Sea, where the northern extension of the Danakil Rift parallels the spreading center (Lowell and Genik, 1972). At the Vøring Plateau the UPLS is presently only preserved in the stratigraphically highest part of the upper series sampled at DSDP Sites 342 and 343. These flows were either never produced or have been eroded at Sites 338 and 642 , located on the more elevated parts of the marginal high. This interpretation is consistent with the timetransgressive nature of the top of the flows, as well as positive polarity of UPLS and that expected in the outer and younger part of the dipping reflector sequence (Fig. 11).

Finally, we point toward some much-neglected seafloor samples from an intrusion in Mesozoic and Tertiary sediments on the Norwegian inner shelf at about $63^{\circ} \mathrm{N}$. The recovered volcanic rock was porphyritic olivine-nephelinite yielding a $\mathrm{K}-\mathrm{Ar}$ age of $55 \pm 0.9 \mathrm{Ma}$ (Bugge et al., 1980). These rocks were intruded outside the area of early Tertiary extension. Similar rock assemblages west of the rifted northern East Greenland volcanic province have given $\mathrm{K}-\mathrm{Ar}$ ages from 44 to $58 \mathrm{Ma}$ (Brooks et al., 1979). Hence, rifting also appears to have affected the lithosphere outside the region of crustal deformation, in a kind of "back-volcanic margin" setting, producing small-scale melting at relatively large mantle depths (Nielsen, 1987).

\section{Plate Tectonic Evolution and Continent/Ocean Boundary}

The pre- and post-opening volcanism at and around the plate boundaries of the North Atlantic make locating the continent/ ocean boundary, defined as the change from continental to oceanic basement, difficult for two main reasons. First, the large lava complexes tend to obscure the underlying geology. Second, the mode of emplacement of the igneous rocks might rule out a distinct boundary in favor of a transitional region of heavily contaminated continental crust.

Site 642 shows that the inner part of the dipping wedge overlies crust of continental affinity at the Vøring Plateau. Skogseid and Eldholm (1987) showed that the flows of the inner wedge onlap reflector $\mathrm{K}$, whereas no base was recognized beneath the main outer wedge overlain by anomaly $24 \mathrm{~B}$. The generation of the dipping wedge was interpreted according to Mutter et al. (1982). However, Leg 104 proves that considerable extrusion over neighboring continental crust was also involved. We place the continent/ocean boundary east of anomaly 24B, just seaward of the termination of reflector $\mathrm{K}$ in a structural position similar to that suggested by Smythe (1983) for the Faeroe-Shetland marginal high. Larsen and Jakobsdóttir (1988) imply a similar relationship for the seaward-dipping reflector sequences off Greenland. Skogseid and Eldholm (1987) have inferred that the region between the continent/ocean boundary and the Vøring Plateau Escarpment (Fig. 2) is highly intruded, characterizing it as transitional. This is consistent with Site 642 results, but Eldholm and Skogseid (this volume) extend the transitional region to include the sill-flow complex in the adjacent Vøring Basin (Fig. 7).

Without entering into a discussion of continent/ocean transitions in general, we note that the Vøring Plateau concept might apply to volcanic margins elsewhere. However, we would like to consider the effects of crustal contamination (Perry et al., 1987) which, in addition to seismic velocity structure and gravity/ magnetic modeling, often are used to distinguish crustal type at passive margins. The ambiguity of the geophysical data has been discussed previously, but we bring attention to the radiogenic isotopes in the tholeiites that have been used to infer the mode of emplacement (Gariépy et al., 1983; Morton and Taylor, 1987).
Actually, some flows and dikes of the Site 642 upper series show evidence of minor contamination by upper crustal rocks (Viereck et al., 1988). This is not surprising, if the flows were emplaced by subaerial spreading. First, the lower series dikes at Site 642 show that some asthenospheric material moved through the adjacent continental crust during initial spreading, thus being prone to contamination (Fig. 12). The same effect would be caused by magmatic stoping from the sides of a virginal oceanic plug subsequent to breakup. Both effects should abate with time, hence being testable by drilling a transect across the dipping wedge.

The local plate tectonic evolution of the central region from Iceland to the Jan Mayen Fracture Zone system is complex and poorly understood as a result of subaerial spreading, axial migration and, at times, dual spreading centers (Talwani and Eldholm, 1977; Nunns, 1983; Larsen, 1978, 1988; Bott, 1985, 1987). Here, we restrict our comments to the early Tertiary volcanic activity and bring attention to the important observation that the incipient Reykjanes and Mohns Ridges line up along an almost straight, more than 2000-km-long lineament, the ReykjanesMohns Line (Fig. 9). In our interpretation (Fig. 10), the prebreakup extrusion of tholeiitic rocks is limited to the transverse part of NAVP and the area to the south, possibly extending as far north as the Jan Mayen Fracture Zone (Fig. 9). The volcanism was most intense under the proto-Iceland hotspot, leaving the thick lavas of the Blosseville Coast and the Faeroes. The Blosseville Coast plateau basalts were extruded from feeders in the east and offshore (Larsen and Watt, 1985), placing the zone of injection along the Reykjanes-Mohns Line (Fig. 9). Within the hotspot, a temporal progression of intraplate injection centers between the Faeroes and East Greenland is envisaged by Waagstein (1988) from compositional differences of the lavas. We instead follow Larsen and Watt (1985), who link the magmatic events in both areas but ascribe differences to heterogeneities in the mantle.

In the middle of Chron $24.2 \mathrm{R}$, seafloor spreading started along the entire Reykjanes-Mohns Line. From the onset of spreading to about anomaly $24 \mathrm{~A}$ time, the accretion of oceanic crust was subaerial along almost the entire plate boundary. This period of about $1.5 \mathrm{~m}$.y. added the longitudinal part of the NAVP (Fig. 9). Locally, the subaerial spreading continued for a longer period dependant on initial elevation, thermal subsidence, and tectonism (Skogseid and Eldholm, 1987, this volume; Larsen and Jakobsdóttir, 1988). However, the central region became the locus of competing spreading centers. Breakup did not take place along the main feeders for the plateau basalts, but moved east, creating the Jan Mayen Fracture Zone and probably another fracture zone farther south. A failed attempt for volcanism to move back to the Blosseville Coast is recorded by a normally magnetized coast-parallel dike swarm, probably at anomaly 24B time. The intrusions were accompanied by rotation of fault blocks creating magnetic lineations that Larsen (1988) has defined as the East Greenland Extinct Axis (EGAX, Fig. 9).

North of the Jan Mayen Fracture Zone, volcanism appears to have been pre-dominantly syn- and post-opening. It might be significant that the lavas of the northern East Greenland province are located between the Jan Mayen and Lofoten fracture zones in a pre-opening reconstruction (Fig. 9). These fracture zones also bound the Vøring Plateau marginal high.

Rifting propagating northward subsequent to the initial breakup has been advocated by Vink (1982) and Larsen (1988). For example, Larsen (1988) argues that propagation is reflected by a narrowing zone of pre-anomaly 24 oceanic crust without documenting it by reconstructions. This hinges to some extent on the crustal nature of the West Rockall Margin. Although the DSDP Leg 81 heat-flow data are compatible with oceanic crust below the dipping reflectors (Hyndman and Roberts, 1987), most 
evidence suggests emplacement prior to breakup as shown in Figure 10. Seismic data farther north, however, indicate that the dipping reflectors overlie both oceanic and extended continental crust in a setting similar to the Vøring Plateau (White et al., 1987b).

\section{VOLCANIC MARGIN EVOLUTION}

The emplacement model for the rocks drilled at Site 642 describes the volcanic evolution of the Vøring Margin and the relationship with the other volcanic margins in the NAVP. A next step is to evaluate the geological conditions and geodynamical processes that create this margin type, as opposed to the nonvolcanic margin characterized by high extension and normal block-faulting during rifting. Both excellent seismic coverage and DSDP/ODP drilling have made the Vøring Margin play a prominent role in developing models for dipping reflector formation and genesis of volcanic margins in general. Such models have normally been based on two assumptions: (1) symmetrical generation of dipping reflector sequences, and (2) volcanism as part of a non-extensional structural regime. Although we have shown that a symmetrical breakup model satisfies many observations, other data bring into question these fundamental assumptions.

The sub-basement reflectors in the NAVP vary in continuity, dip, amplitude, and reflection pattern within Zones II and III. We believe the variety in style of the reflectors reflects variations in magma production and constructional environment along the plate boundary. In particular, there are several different kinds of seaward-dipping reflectors (Hinz et al., 1987; Skogseid and Eldholm, 1987; Larsen and Jakobsdóttir, 1988), and a classification has been proposed by Parson et al. (1988). The arcuate, divergent type characterized by increasing dip with depth and a general seaward stratigraphic offlap (i.e., the main inner wedges at the Vøring Plateau) are typical for lava flows created by subaerial spreading. However, conditions of rapid subsidence and high extrusion rates are required to construct the wedges.

We now turn to the variation in style and setting of sub-basement reflectors, evidence of margin asymmetry, and non-extensional nature of the margin. The discussion is primarily restricted to the margins on either side of Mohns Ridge (Fig. 1), the part of the Norwegian-Greenland Sea that has undergone the simplest plate tectonic evolution. However, scarcity of data from the conjugate Greenland margin makes a direct comparison difficult.

\section{Margin Asymmetry}

Several lines of evidence point toward asymmetry in the crustal configuration prior to breakup, as well as in the generation of lower Tertiary oceanic crust. The line of breakup crosses the large sedimentary basin region between Norway and Greenland diagonally between the Jan Mayen and Greenland-Senja fracture zones. Thus, the crust split apart in areas of varying sedimentary and crustal thickness, presumably having different crustal strengths. In the south, the main basin region lies on the Norwegian margin east of the Vøring Plateau marginal high, whereas its northern counterpart is found on the Greenland Margin west of the Greenland marginal high (Fig. 1).

Early opening reconstructions show that the Vøring and Greenland marginal highs constitute a volcanic feature along the entire rift separated by the Lofoten Fracture Zone (Figs. 1 and 2). The location of the highs with respect to the magnetic lineations implies that they were constructed mainly on opposite sides of the plate boundary. Adjustments and minor shifts in the pre-anomaly 23 spreading axis (Hagevang et al., 1983) do not affect this pattern. Asymmetry is further supported by the absence of similar constructions conjugate to the highs. Actually, both conjugate margins exhibit small, local highs near the base of the slope covered by a smooth, opaque basement reflector extending toward the shelf edge, and locally also onto the shelf (Eldholm et al. 1979; Hinz et al., 1987).

A major problem with previous models explaining the dipping wedges is that they require a symmetric wedge at the conjugate margin or a wedge, or partial wedge, of opposite polarity at the same margin if an axial jump has occurred. Presently, we believe that no clear symmetry of conjugate sets of dipping reflectors have been clearly demonstrated. Where dipping beds exist on either side of the ocean, one of the "pairs" is by far the best developed. This is particularly the case for Vøring Plateau Zone IIIA, and similar wedges off East Greenland (Larsen and Jakobsdóttir, 1988). However, our interpretation differs from that of Hinz et al. (1987), who claim an almost perfect conjugate mirror image of the Vøring Plateau dipping sequence.

\section{Early Tertiary Extension}

The idea of volcanic margins in a non-extensional structural setting developed from the apparent absence of a rift unconformity and early Tertiary faulting prior to the opening of the Norwegian-Greenland Sea (Hinz et al., 1987; Mutter et al, 1988). When compared with a symmetrical pure-shear model of crustal extension (Le Pichon and Sibuet, 1981), the Vøring Margin appears tectonically undisturbed. However, several lines of evidence indicate pre-opening crustal extension at the eastern margin of the Lofoten Basin:

1. Large, normal basement faults at the northern LofotenVesterålen Margin (Fig. 1). These faults, which have not involved the overlying sediments (Eldholm et al., 1979), are conjugate to the Greenland marginal high.

2. Pre-opening magmatism in the Vøring Basin, which has left an extensive intrusive complex east of the continent/ocean boundary, implying crustal extension (Royden et al., 1980).

3. Basin analysis of the Vøring Basin, which is compatible with two extensional phases, one in the Late Jurassic-Early Cretaceous and the other during early Tertiary time (Pedersen and Skogseid, this volume).

4. Formation of Paleocene to earliest Eocene listric normal faults and an early Tertiary rift unconformity in the outer Vøring Basin (Fig. 7) (Skogseid and Eldholm, this volume).

\section{Asymmetric Extension Model}

The preceding observations led us to investigate an alternative model that accounts for the observed asymmetry and extension. In addition, it provides a tectonic mechanism for generation of the dipping reflector wedges. Although the subsidence of the wedge is normally assumed to be a function of loading and thermal subsidence only (Fig. 11), an additional tectonic force would be convenient in view of the short construction period of the more than 5- to 6-km thick wedges. Therefore, we evaluate an asymmetric simple-shear extension model based on a continentward dipping listric fault system with an upper detachment plane at the brittle-ductile crustal transiton (Fig. 13) similar to the delamination model of Lister et al. (1986):

1. Pre-opening phase. Crustal extension by listric faulting occurs, located in a region of ascending asthenosphere. The detachment plane may correspond to a distinct lower crustal reflector (LCR) beneath the Smøla Rift (Fig. 7). The combined effects of temperature and lateral unloading of the upper crust arches the listric fault region. Associated uplift and erosion creates a rift unconformity, and antithetic normal listric faults are formed in the Vøring Basin.

2. Earliest subaerial seafloor spreading. Breakup occurs in a location with only one major listric fault block landward of the line of opening. The most landward main fault plane becomes 

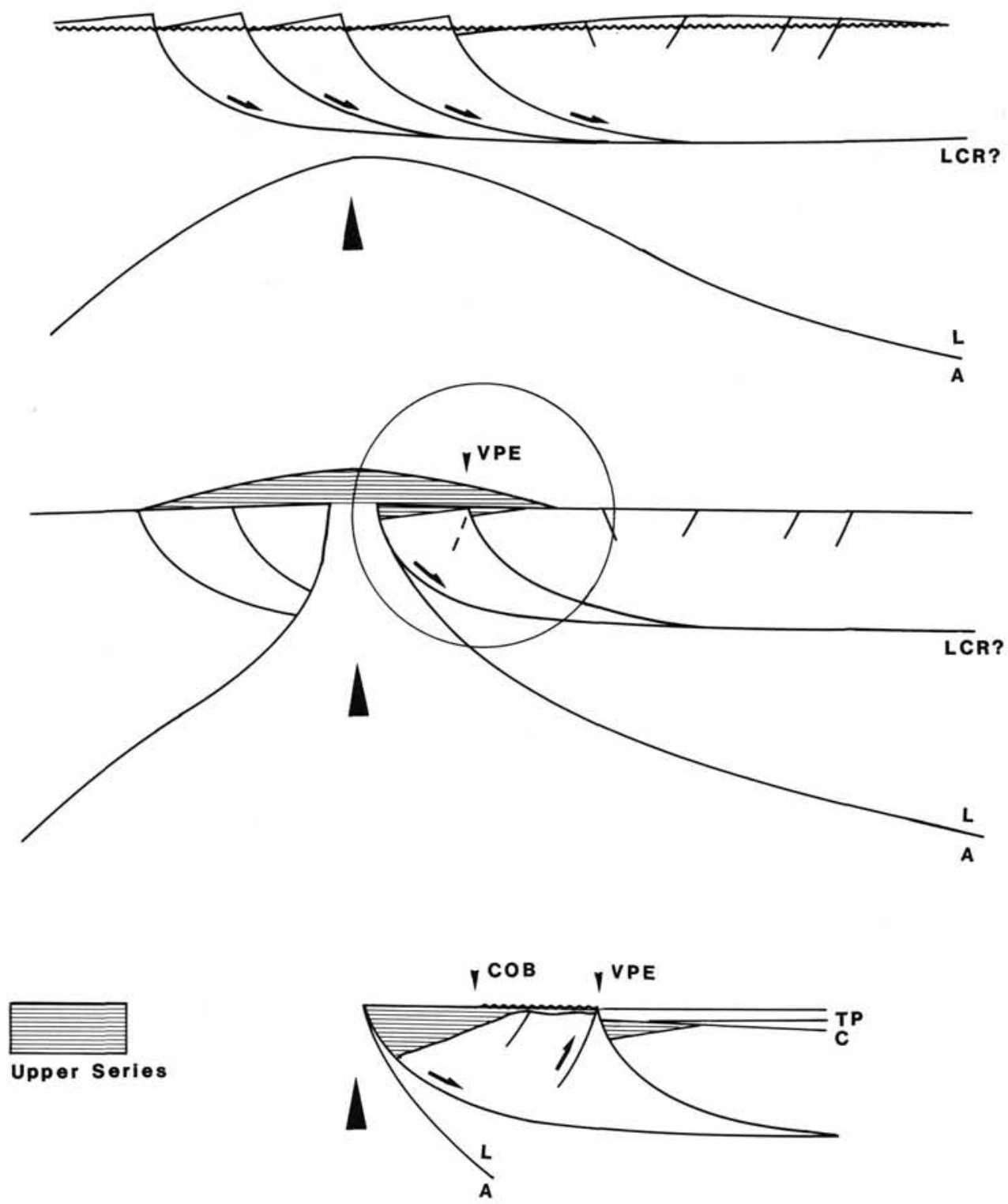

Figure 13. Evolutionary sketch demonstrating tilting of the outer Vøring Plateau assuming asymmetric crustal extension with breakup on the eastern side of the rifted region. Sketch not to scale. VPE: Vøring Plateau Escarpment; COB: continent/ocean boundary; TP: lowermost Eocene ash marker; C: base Tertiary; LCR: lower crustal reflector; L: lithosphere; A: asthenosphere.

the initial Vøring Plateau Escarpment. At this time, motion along the rift system ceases except for the block landward of the spreading axis. Lava flows and underlying dikes accrete new oceanic crust that is welded to the older contaminated continental crust, gradually subsiding to form the typical dipping pattern. Landward of the spreading axis, continued listric movement of the fault block provides a tectonic force to amplify the subsidence of the extrusives forming the dipping wedge. This mechanism was originally proposed for rifting in Iceland by Gibson and Gibbs (1987), and a generalized application to the Vøring Plateau is suggested by Gibson and Love (this volume).

The rotating fault block continuously grows on its seaward side, in effect because it is bounded by a westward-migrating "pseudo-listric" fault. This will cause a space problem that is partly accomodated by the nonrigid western boundary and internal deformation, but also by antithetic faults in the vicinity of the escarpment causing tilting of the block and uplift west of the escarpment. These movements are compatible with the se- quence stratigraphy over the marginal high and the predicted motion along the Vøring Plateau Escarpment, accounting for the initial offset between the flows in Zone II and those of the sill-flow complex east of the escarpment (Zone I).

The crust on the conjugate margin was less receptive to subsidence as a result of the absence of a tectonic force. Therefore, more of the extrusives were removed by erosion. Consequently, one might expect a less prominent volcanic edifice at this margin, which elegantly explains the lack of dipping reflectors beneath the western $24 \mathrm{~A}-\mathrm{B}$ anomaly sequence at the southern Vøring Plateau. The listric system may also have acted as conduits for the northern East Greenland intraplate volcanism.

3. As the initial excessive volcanism abates, the additional load diminishes and the relative motion of the block is expected to slow down. Seismic data indicate that the tilting and corresponding movement along the Vøring Plateau Escarpment gradually decreased, but continued toward the end of Oligocene time (Skogseid and Eldholm, this volume). 
If we extend the asymmetric rifting concept to the areas north of the Vøring Plateau, the structural setting might be explained by a detachment plane of opposite polarity. This suggests that the location of the Lofoten Fracture Zone was predetermined by a Paleocene transfer fault.

Except for a suggestion concerning rejuvenation of Late Jurassic-Early Cretaceous boundary faults prior to opening, uplifting a block west of the northern East Greenland basalts (Upton, 1988), the main part of the asymmetric rift system is not documented by observational data and the evolution is indeed simplified. Neither is the above concept intended as a solution to every segment of North Atlantic volcanic margins, ruling out weakly extended crust and symmetric development of volcanic margin segments. However, we suggest that asymmetric models be considered where the conjugate margins exhibit considerable differences in structural and volcanic style.

\section{Crustal Structure}

The Vøring Plateau Escarpment marks a major discontinuity in the lateral distribution of shallow seismic velocties. In the Vøring Basin a $6+\mathrm{km} / \mathrm{s}$ velocity has been associated with a crystalline basement at a depth of as much at $10-12 \mathrm{~km}$, while $4.0-5.0 \mathrm{~km} / \mathrm{s}$ have been measured at the sediment-flow contact and the top of the oceanic basement west of the escarpment (Myhre, 1984; Mutter et al., 1984, Eldholm and Mutter, 1986; Skogseid and Eldholm, this volume). For the dipping reflectors an increasing velocity with depth from about 4.0 to $6.0 \mathrm{~km} / \mathrm{s}$ appears representative (Mutter et al., 1982) and consistent with Site 642 data (Eldholm, Thiede, Taylor et al., 1987; Barton et al., this volume).

ESP's have been recorded by L-DGO (Mutter et al., 1984, 1988; Mutter and Zehnder, 1988) and Elf Aquitaine (Planke et al., unpublished data) along transects across the northern Vøring Plateau. The profiles show three main crustal units separated by the escarpment and the outer foot of the plateau (Fig. 14). The outer Vøring Basin has a crustal thickness of about $20 \mathrm{~km}$ and the velocity structure is indicative of thinned continental crust, whereas that in the Lofoten Basin is oceanic. In the intermediate region, however, the crust changes character. There, the upper crust is similar to oceanic crust, but the lower crust, which is characterized by velocities greater than $7.0 \mathrm{~km} / \mathrm{s}$, expands beneath the dipping reflector sequences, reaching a maximum depth to Moho of about $24 \mathrm{~km}$ beneath the main inner wedge. However, the thickening is considerably less under the poorly developed outer wedge (Fig. 14). The velocity-depth profiles between the inner wedge and the escarpment (Zone II, Fig. 2) differ from those on either side, and include a shallow low-velocity zone reported by Mutter et al. (1984). These data lend support to transitional crust in this region (Skogseid and Eldholm, 1987). Crustal thickening below the dipping reflectors and a crustal transition in Zone II is also found beneath the Faeroe-Shetland marginal high (Ólafsson, 1988).

A crustal structure similar to the Vøring Plateau is reported off Greenland north of the West Jan Mayen Fracture Zone by Mutter and Zehnder (1988). At the west Rockall Margin, the dipping sequence exhibits velocities similar to those of the main wedges at the Vøring Plateau (Whitmarsh and Miles, 1987), while a 10 - to $15-\mathrm{km}$ thick lense of $7.3-7.4 \mathrm{~km} / \mathrm{s}$ material is mapped under the dipping reflector sequence (White et al., 1987b). Larsen and Jakobsdóttir (1988), on the other hand, suggest a horizonal Moho below the seaward-dipping wedge at the conjugate Greenland margin. We note that their lower crustal velocities are poor and the base of the crust is indicated from gravity data. In summary, we judge that an increased crustal thickness, including a high-velocity lower crust, is reasonably well documented beneath the majority of volcanic margin segments in the North Atlantic.

\section{Geodynamic Mechanisms}

Application of thermo-mechanical models for lithospheric deformation has proven to be valuable in describing the firstorder effects of processes leading to continental thinning and crustal breakup. For example, models based on uniform extension of the lithosphere have successfully been applied to simulate initiation and evolution of a number of passive continental margins (Le Pichon and Sibuet, 1981). The early evolution of the volcanic margins in the North Atlantic, on the other hand, suggests a partially different mode of formation for the following reasons:

1. The huge volcanic edifices along the margins imply an increased rate of magma production during initial opening. Moreover, the distribution of extrusives and pyroclastics indicate that the magnitude of volcanism wanes rapidly after the initial surge (Fig. 11). Using the Pálmason (1973, 1980) kinematic model, Larsen and Jakobsdóttir (1988) have calculated a rate of magma production off East Greenland that is initially about three times greater than presently observed in Iceland.

2. The lack of initial subsidence, which causes subaerial accretion of oceanic crust.

3. The pre-opening crustal configuration, including simultaneous breakup across regions of different sedimentary and crustal thicknesses.

4. The influence of the Iceland hotspot. This phenomenon, which documents a thermal anomaly in the mantle lasting at least $60 \mathrm{~m} . y$. , may have funneled energy over an area far larger than its actual surface manifestation.

5. The fact that the 60 -m.y.-old hotspot trail is surrounded by steep flanks implies a regionally limited conduit, whereas the transient surge of margin volcanism extending over a distance of $2000 \mathrm{~km}$ lasted not more than $3 \mathrm{~m}$.y.

6. Thickened high-velocity crust under parts of the volcanic margins.

Constraints from Site 642 results and improved seismic imaging allow quantitative geodynamic modeling of processes creating volcanism and margin uplift. Recent activities in this field have developed along two main lines of argument, depending on whether the model requires a hotspot or not.

\section{Non-hotspot-dependent Models}

The crust at the Vøring Margin that underwent major extension in the Late Jurassic-Early Cretaceous had also been thinned during previous rift phases (Skogseid and Eldholm, this volume). Assuming uniform crustal extension and available extension estimates, Skogseid and Eldholm (1987) inferred that initial uplift or nonsubsidence could take place during breakup, producing subaerial oceanic crust. Subsequent work has shown that the Mesozoic extension rates probably were too high, but Skogseid and Eldholm (1988) demonstrated that a two-layer extensional model with a very small crustal extension rate and $50 \%$ dike intrusion during rifting would provide the neccessary uplift. Pedersen and Skogseid (this volume) have refined this model, showing that the Vøring Margin experienced at least two distinct rift phases, of which the early Tertiary phase initiated the Tertiary Marginal Basin (Fig. 2). They also calculated that a process of differential, lateral lithospheric extension with partial melting in the ascending upper mantle accounts for both induced uplift and magma production, if there is a small (i.e., about $50^{\circ} \mathrm{C}$ ) temperature increase at the base of the lithosphere.

Another approach by which magma production exceeds that of passive upwelling during extension is advocated by Mutter et al. (1988). Their concept is based on the existence of a distinct crustal transition beneath the volcanic margin, which mirrors a 


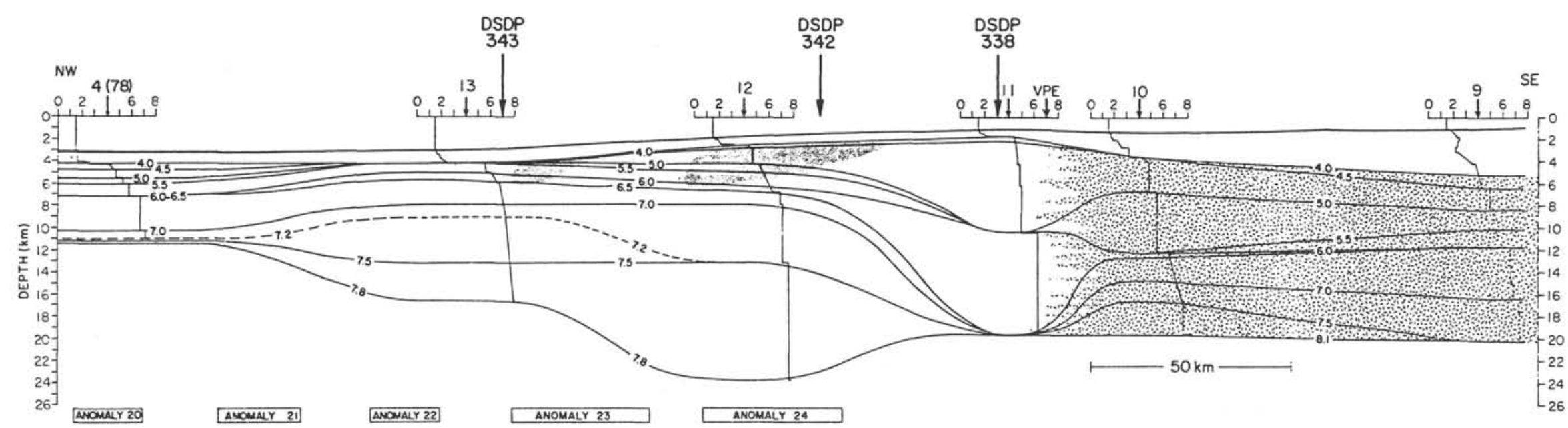

Figure 14. Crustal velocity structure based on ESP results along a transect across the Vøring Plateau north of the Vøring Fracture Zone (Mutter et al., 1988). Shaded area west of the Vøring Plateau Escarpment (VPE) shows the dipping reflector, whereas the shading east of VPE marks the extent of thinned continental crust according to Mutter et al, (1988). 
similar, abrupt contrast between cold lithosphere and hot, ascending asthenosphere during rifting. Pronounced lateral temperature gradients under the nascent rift induce vigorous convection, which enhances partial melting and results in excess magma production. The excess magma constitutes the dipping reflector units and the underlying thickened lower crust. This is essentially a passive rifting process not involving the asthenosphere. The rifting is caused by stresses transmitted by a mechanically strong lithosphere, contrasting with the active process originating from temperature differentials in the asthenosphere (Bott, 1976). The narrow asthenospheric conduit required to provide the lateral temperature differential needed in the Mutter et al. (1988) model is obtained by assuming no pre-breakup extension. Thus, the actual breakup is envisaged as a simple split of the lithosphere. The split occurs preferentially at regions of low crustal strength. At the Vøring Margin, opening along a Mesozoic high at the western Smøla Rift is proposed.

\section{Hotspot Models}

On a regional scale, the North Atlantic is more elevated than oceans of comparable age elsewhere (Talwani and Eldholm, 1977; Cochran and Talwani, 1977) a fact often attributed to hotspots or deep, narrow mantle plumes (Vogt and Avery, 1974; Schilling and Noe-Nygaard, 1974). Except for Iceland, Talwani and Eldholm (1977) argue against ascribing all the anomalous crust in the Norwegian-Greenland Sea (Fig. 15) to narrow plumes, and conclude that most observations are satisfied by a regional hotspot active during the history of seafloor spreading in the North Atlantic. Accordingly, the shallow crust originates when the plate boundary stays within the hotspot region. On the other hand, they consider the elevation of the marginal highs a transient opening phenomenon, probably related to the chemistry of the initial basalts produced under the continent being split apart, or with thermal conditions during breakup that may produce increased magmatism. Cochran and Talwani (1978) calculate that a temperature increase at the base of the lithosphere of about $75^{\circ} \mathrm{C}$ would compensate for the observed regional depth anomalies in the North Atlantic.

Vink (1984) predicted that if a mantle plume was located in the proximity of the plate boundary, asthenosphere would be channeled to the part of the spreading center closest to the hotspot. In turn, excess basalt and thicker crust would be produced where the feeder met the plate boundary, thereby explaining the evolution of the Vøring marginal high and the Faeroe-Greenland Transverse Ridge. However, the large extent of the marginal volcanism appears to rule out a selective feeder channel (Fig. 9). Meissner and Köpnick (1987) place the rift zone directly over a rising plume surrounded by low-viscosity layers both in the asthenosphere and the lower crust. They explain data from the Vøring Plateau to reflect a laterally intruding plume that induces extension and crustal thinning and some volcanism prior to spreading. At this time, there is a peak in volcanic activity, forming the dipping reflectors, and magma laterally intruded into the lower crust forms the high-velocity material below the extrusives.

White et al. (1987a) applied a model of partial melting by decompression of passively upwelling asthenosphere as the continental lithosphere is stretched and thinned beneath the rift. Because the amount of partial melt depends on the temperature of the asthenosphere and the degree of decompression, they ascribe the differences in magmatism and vertical motion between volcanic and nonvolcanic margins to a $100-150^{\circ} \mathrm{C}$ hotter asthenosphere beneath the volcanic margin. The North Atlantic acquired the increased temperature by heat advection from the Iceland hotspot, explaining subaerial crustal genetration and emplacement of the high-velocity lid at the base of the crust. This mechanism is supported by Bott (1988), who applied whole-

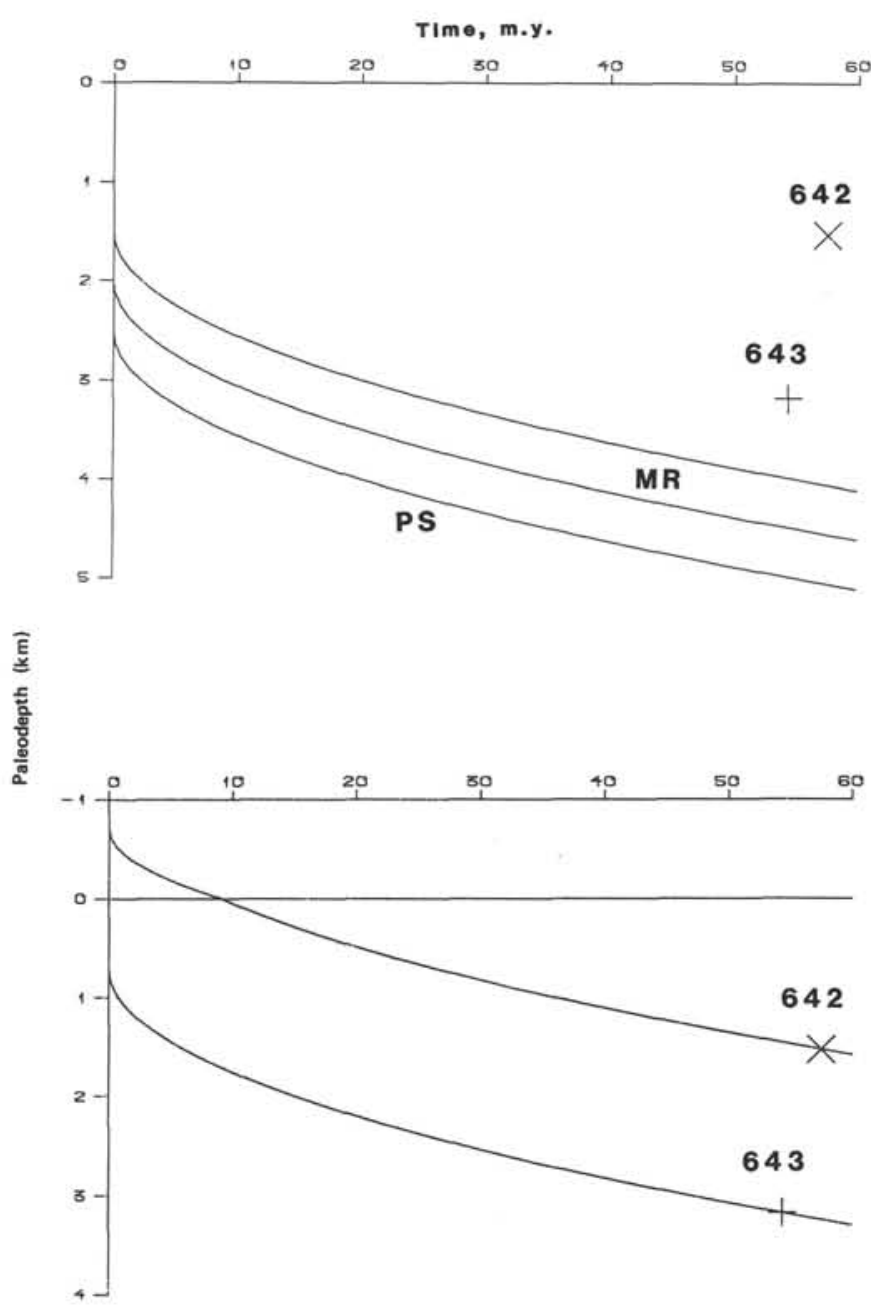

Figure 15. Top: Level of igneous crust at Sites 642 and 643 compensated for sediment load, and a standard age-depth curve for oceanic basement (PS), Depth $=2500+336(\text { Age })^{1 / 2}$ (Parsons and Sclater, 1977), compared with similar curves for Mohns Ridge (MR) assuming 1500- and 2000-m axial depths. Bottom: The Parsons and Sclater age-depth curve constrained to pass through the offloaded top of the igneous basement at Sites 642 and 643.

mantle convection to postulate a lower mantle plume below Iceland in response to subduction at the edge of the Pacific Plate.

\section{Model Evaluation}

The models of Mutter et al. (1988) and White et al. (1987a) are distinctly different, while the other approaches are of intermediate nature. In particular, the end product of Meissner and Köpnick (1987) and Skogseid and Eldholm (1988) yields a margin resembling the intrusion model of Royden et al. (1980), whereas temperature increases at the base of the lithosphere inherent in the crustal extension model of Pedersen and Skogseid (this volume) do not necessarily imply a hotspot.

The model of Mutter et al. (1988), largely developed from the Vøring Plateau data, is based on a relatively simple geologic framework. The new seismic data reveal a complex stress situation during breakup and the emplacement of lower Tertiary igneous crust that must have been associated with lithospheric extension (Pedersen and Skogseid, this volume). The highly intruded region between the continent/ocean boundary and the landward termination of the inner flows as well as the intrusions in the Tertiary Marginal Basin (Fig. 7) suggest heating of the 
rifted region prior to opening. Therefore, we anticipate a more gradual lateral temperature distribution than the hot-cold situation needed to initiate convective melting in the narrow asthenospheric conduit. This situation would still exist if the continent/ ocean boundary is placed near the escarpment, as implied by Mutter et al. (1988). Finally, the time lapse between the start of seafloor spreading and maximum melt generation implicit in the model appears inconsistent with the indications of a maximum volcanic surge at, or just after, breakup.

According to White et al. (1987a) and White (1988), the thermal properties of the $2000-\mathrm{km}$ diameter mushroom-shaped hotspot, centered over the Iceland plume at the time of rifting, are considered similar to those calculated for the Cape Verde hotspot by Courtney and White (1986). They claim that the old, thick lithosphere over the Cape Verde hotspot is similar to the North Atlantic prior to opening. In view of this analogy, we note that the opening between Eurasia and Greenland occurred in continental, locally very old lithosphere, whereas Cape Verde lies over oceanic crust. Nevertheless, the basic concept of White et al. (1987a) is quite similar to that advocated by Talwani and Eldholm (1977), namely, that abnormal conditions will occur when the plate boundary crosses the hotspot region. Similarly, the transient nature of the margin magmatism is ascribed to changes in basalt chemistry and temperature. Actually, the relative change in crustal thickness and magma production shortly after breakup is related to (White, 1988): (1) focusing of melt towards the margin during early rifting as a result of pressure perturbations creating an underplated igneous lense, and (2) breakthrough of the central plume that advects heat out of the asthenosphere, leaving depleted material of lowered temperature to flow laterally from the plume.

The main difficulty with the approach of White et al, (1987a) relates to the magnitude of the asthenosphere temperature in the hotspot mushroom. In fact, the hotspot will cause dynamic uplift over the entire area prior to rifting (White, 1988). This event should be recognized in the geological record over a large region diminishing toward the circumference of the hotspot. The rocks at the margin off Norway have no record of this event. The Paleocene uplift at the Vøring Plateau, which is limited to the area adjacent to line of breakup, was initiated after the onset of rifting, reflecting the isostatic response to the changing lithosphere.

In our opinion, the early Tertiary magmatism has to relate, in some way, to the Iceland hotspot. The crustal morphology of the Faeroe-Greenland transverse ridge suggests, however, that the effects of the main plume abate rapidly from its center. This observation argues against the plume model of Meissner and Köpnick (1987), which does not take into account the contemporaneous magmatism along the entire plate boundary. On the other hand, the increased asthenosphere temperature in the North Atlantic (Cochran and Talwani, 1978) is probably induced and maintained by the Iceland and other hotspots (e.g., Azores, Yermak). A lower temperature contrast at the base of the lithosphere, over an even larger area than the Iceland hotspot, might produce a smaller dynamic uplift, having little influence on the relative depositional patterns in the North Atlantic realm. We visualize this effect as a higher temperature "carpet," rather than a "mushroom." When the lithosphere comes under stress, the temperature of the passively upwelling asthenosphere induces partial melting, producing the excess melts. The partial melting, differential crustal extension, and pre-rifting crustal configuration provides conditions for initial elevation or nonsubsidence, as shown by Pedersen and Skogseid (this volume). We stress that the above approach is not dependent on a hotspot for providing the increased heat, although a hotspot indeed provides a convenient source.

The reason for the rapid decrease in magmatic production after the initial breakup surge is still considered poorly under- stood. Additional modeling of the breakup process might clarify the issue, however drilling of transects extending onto crust accreted at a normal spreading axis are most needed. Work of this kind should acknowledge the much-increased spreading rate during emplacement of excess magma.

Comparison of the mechanical strength for stretched and unstretched continental lithosphere shows that the unstretched regions possess the least strength (Mutter et al., 1988). It is therefore tempting to suggest that the absence of an early Tertiary faulted rift surface over the entire Vøring Margin is caused by a strong lithosphere beneath the pre-opening sedimentary basins. If we add the crustal extension caused by the pre-opening intrusive activity, there is ample evidence for not relating the volcanic Vøring Margin to lithospheric non-extension.

The high-velocity, lower crustal bodies below the dipping reflectors could be interpreted as underplated asthenosphere, or a strongly intruded continental unit (White et al., 1987b). However, underplating is assumed in all the models above. Consequently, the underplated body contributes significantly to the amount of excessive magma to be accounted for. On the other hand, little work has been done on the degree and methods of compensation of marginal volcanic complexes. If the underplated body represents a simple isostatic compensation of the extra near-surface igneous load, their emplacement might be delayed with respect to the volcanic surge. In such a case, alternative modes of emplacement are possible, thus lowering the amount of melt produced during rifting.

\section{POST-RIFT EVOLUTION}

\section{Subsidence}

After the initial pulse of excessive volcanism, the margin subsided primarily by thermal cooling and contraction. The anomaly 23 age (53.9-54.7 Ma) crust at Site 643 was probably produced under oceanic conditions, while the subsidence of the northern plateau may have been delayed at this time, creating the shallow subparallel dipping reflectors in Zone IIIB (Fig. 2), and the possible sills at the bottom of Site 343 (Talwani, Udintsev et al., 1976). A main question is to determine how the outer margin subsided with time, allowing for the accretion of the oldest crust at the anomalously shallow levels. Presently, there is an about 3-km difference in basement elevation between the shallowest marginal high and the Lofoten Basin (Fig. 7). Moreover, the unloaded basement depth at Site 643 is about $1.7 \mathrm{~km}$ deeper than at Site 642 (Fig. 15). We also have to account for the depth of the Mohns Ridge, which is $0.5-1.0 \mathrm{~km}$ shallower than the average world ocean (Cochran and Talwani, 1978; Zielinski, 1979), although the oceanic crust in the Lofoten Basin has subsided more rapidly than normal (Vestby, 1980).

To illustrate the dramatic depth difference between the Vøring marginal high and normal oceanic crust, we show the unloaded crustal elevation of Sites 642 and 643 with respect to the average age-depth curve of Parsons and Sclater (1977) (Fig. 15). If the standard curve is shifted to pass through the sites, we obtain initial generation of oceanic crust at levels that correspond to drilling results and the calculated uplift at Site 642 (Pedersen and Skogseid, this volume). Seismic data show that the crust in the Lofoten Basin approaches the Mohns Ridge age-depth level (Fig. 15) just to the west of the foot of the Vøring Plateau. This is interpreted in terms of a thermally controlled subsidence both for the basin and the marginal high. This leaves the mechanism for the steep elevation gradient at the outer flank of the plateau. A thermal origin is ruled out because Zielinski (1979) demonstrated that the heat flow distribution is consistent with an oceanic model with a continent/ocean boundary in the vicinity of the Vøring Plateau Escarpment. We ascribe the gradient instead to isostatic compensation of the excess load of intrusives and ex- 
trusives emplaced during the early opening. Using the crustal data in Figure 14 and assuming a decrease in crustal density of $0.1 \mathrm{~g} / \mathrm{cm}^{3}$ from Site 643 to 642 , we compute a change in basement elevation similar to that observed.

The available data do not allow construction of accurate subsidence curves for the two drill sites because of the lack of precise depth indicators in the stratigraphic record and uncertainties in the age of Paleogene sediments (Goll, this volume). Nevertheless, we have outlined the margin subsidence at Sites 642 and 643 by backstripping the sites, correcting for compaction and paleodepth, and assuming Airy-type basement response, using very few data points. The least-square age-depth curve fitted to the data (Fig. 16) probably reflects the gross subsidence pattern since the early Eocene. At Site 643, both the lowermost benthic foraminifers (Osterman and Qvale, this volume) and the sedimentary structures (Eldholm, Thiede, Taylor, et al., 1987) suggest deposition in slope basins or a rapidly subsiding trough with restricted bottom-water circulation. The lowermost $50 \mathrm{~m}$ show a low diversity benthic assemblage deposited at relatively shallow, outer neritic to upper bathyal paleodepths (Kaminski, 1987); while the overlying cores contain a diversified, deep-water assemblage. Thus, deposition at bathyal depths was reached at the beginning of the middle Eocene $(52.0 \mathrm{Ma})$. The basal $10 \mathrm{~m}$, however, are associated with continental soils developed under hot climate with seasonal humidity (Froget et al., this volume). Therefore, the subsidence curve in Figure 16 is initially constrained to zero water depth.

Lithologic Unit IV at Site 642 (Fig. 5) has been deposited in a nearshore environment. Manum et al. (this volume) date the two uppermost cores in this unit as lower Miocene, while $\mathrm{Sr}$ isotope stratigraphy and $\mathrm{Rb}-\mathrm{Sr}$ glauconite analysis of fish teeth and shell fragments by Smalley et al. (this volume) yield late Eocene ages (37-40 Ma). In view of the pronounced lithologic contrast on either side of the hardground in Core 104-642D-11X, we follow Smalley et al. (this volume), and assign an Eocene age also for the upper part of the unit. In addition, the unconformity at the top of the unit suggests that the radiometric ages are minimum values. The least-square age-depth curve in Figure 16 does not include the late Eocene age datapoint, which would increase the zero-time elevation by $80 \mathrm{~m}$ and delay the submergence from about 5 to $6.5 \mathrm{~m} . \mathrm{y}$.

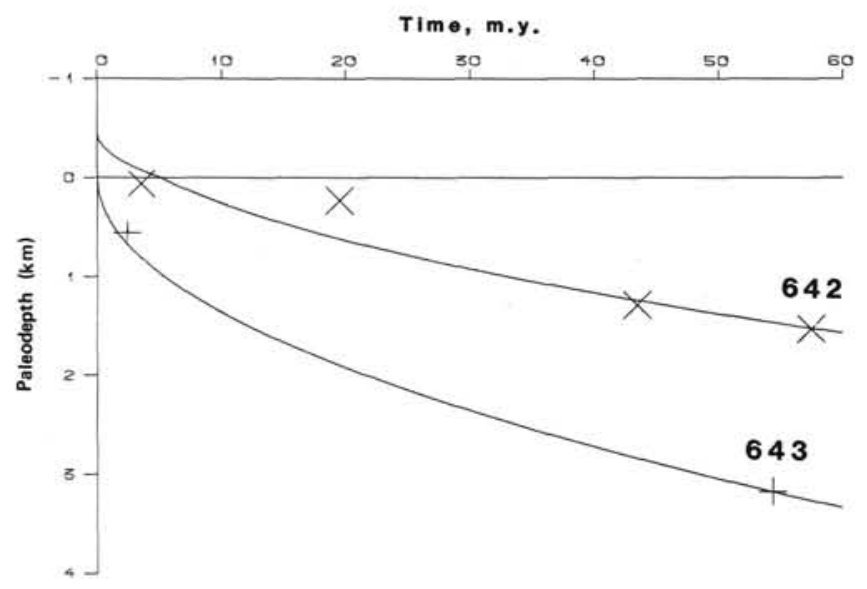

Figure 16. Least-square age-depth curves for Sites 642 and 643 based on subsidence analysis without incorporating sea-level changes. Site 642 , without the datum point at $19 \mathrm{Ma}$ : Depth $=-450+286(\mathrm{Age})^{1 / 2}$; with all points: Depth $=-530+300(\text { Age })^{1 / 2}$. Site 643 : Depth $=431(\text { Age })^{1 / 2}$.

\section{Margin Evolution}

The seismic data provide independent information about the vertical movement of the margin (Skogseid and Eldholm, this volume). By integrating the seismic data, drilling results, and probable timing and magnitude of Site 642 and 643 subsidence, we arrive at a first-order framework for the post-rifting history of the Vøring Margin (Fig. 17).

Toward the end of the early Eocene, the spreading axis rapidly approached the shallow Norwegian-Greenland Sea level of oceanic crust accretion. The outer plateau, which was uplifted prior to opening, was still elevated and being eroded, but the entire margin became part of the regionally subsiding Tertiary Marginal Basin, coupled to the growing oceanic crust in the Lofoten Basin. Basin subsidence and sedimentation smoothed the rift-induced relief, and the sediments transgressed westward in the Vøring Basin, reaching the Vøring Plateau Escarpment in the middle Eocene. Erosional products from the elevated young lavas form the main constituent of the basal sediments above reflector TP in the vicinity of the escarpment and in the basement depression east of Site 643 (Figs. 7 and 17).

From the middle Eocene to middle Oligocene, the sediments covered the inverted Smøla and Fleina rifts, gradually developing a major depocenter in the outer Vøring Basin. The exposed lavas at the inner part of the marginal high were progressively onlapped by sediments, but the summit of the high was still being partially eroded. The relief of the basement depression at the outer high was maintained during regional subsidence. This subsidence, which was accompanied by transgression and deposition of zeolitic mudstones, primarily from source areas to the east, although there was also a contribution from erosion at the western flank in the vicinity of Site 643 .

Except for local highs, the entire marginal high was sediment-covered during early Miocene time (22 Ma). However, the outer plateau appears to have subsided more rapidly than the summit region, leaving marine chalks and siliceous mudstones in the deeper outer region, whereas zeolitic mudstones dominate higher up on the high. In general, biogenic hemipelagic and pelagic material become progressively more dominant with an increasing terrigenous component at the inner margin. Since the lower Miocene unconformity (reflector A, Fig. 17), the margin has been characterized by continued regional subsidence and sedimentation. However, there is ample evidence of both regional and local erosion and redeposition, as well as gravity-induced mass movements. This activity has been attributed to changing bottom currents and sea level, and consolidation effects (Skogseid and Eldholm, this volume). An increasingly distinct calcareous sediment component emerged in the late Miocene, changing into an alternating sequence of carbonate-rich and carbonate-poor glacial deposits in the late Pliocene.

This development implies that the most elevated parts of the inner marginal high stayed above sea level into the early Oligocene, subsiding to a depth of about $500 \mathrm{~m}$ at the beginning of Miocene time. In fact, Skogseid and Eldholm (this volume) show that local lavas north of the Vøring Fracture Zone were not covered by sediments until the late Pliocene.

Finally, we turn to the much-debated nature of the Vøring Plateau Escarpment. Skogseid and Eldholm (this volume) favor a tectonic origin with movements along a reactivated Mesozoic fault. The fault motion was considered most pronounced during and just after breakup, ceasing towards the end of Oligocene times. They also suggest that the seismic expression of the escarpment was amplified by differential marginal subsidence during the Eocene and Oligocene. The asymmetric listric model (Fig. 13) produces similar results, but provides a convenient ad- 

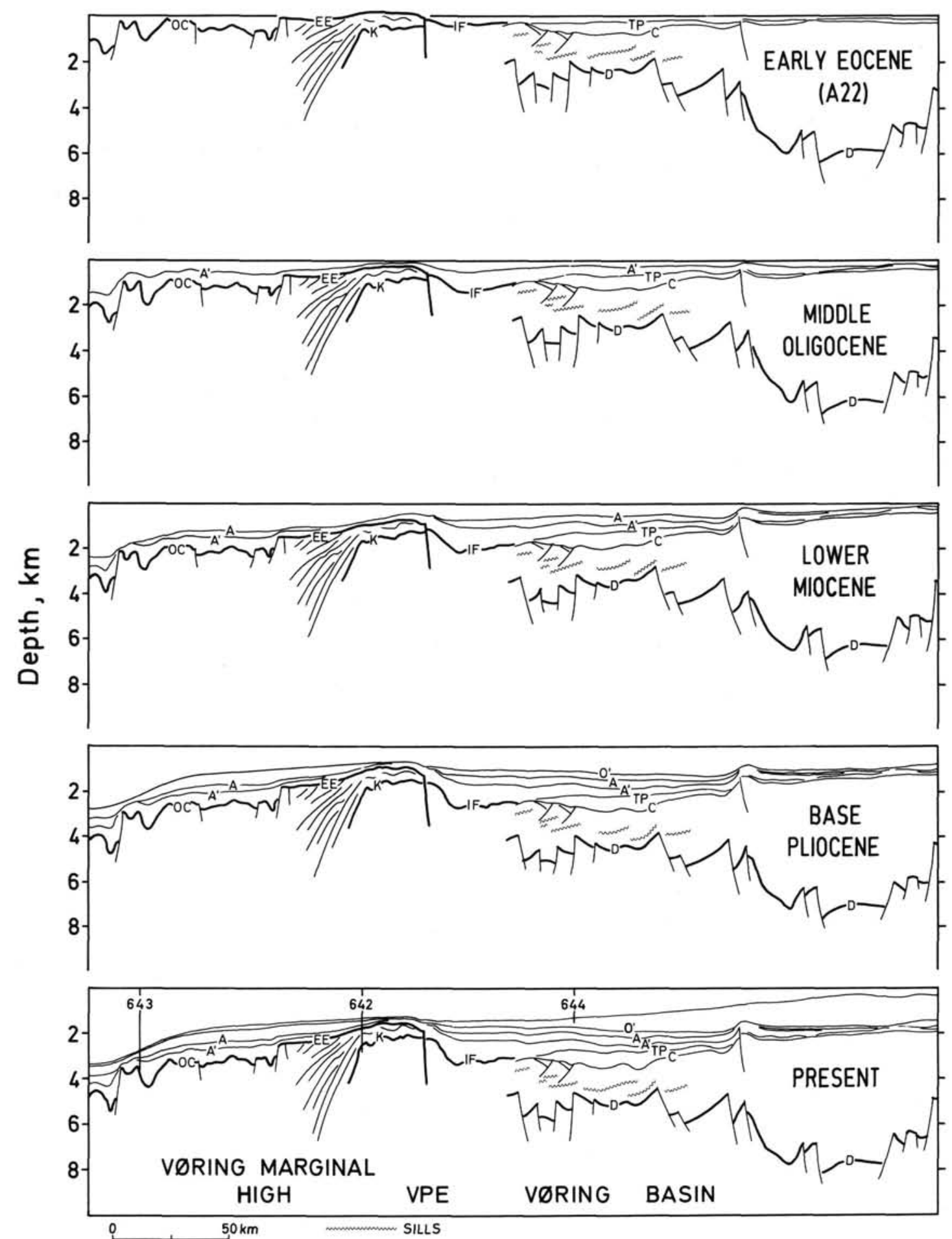

Figure 17. Time slices showing the evolution of the Vøring Margin after the construction of the extrusive marginal complex during initial opening. VPE: Vøring Plateau Escarpment; OC: oceanic crust; K: reflector K (lower series); EE: top lower Eocene flows (upper series); IF: inner flows; D: base Cretaceous; C: base Tertiary; TP: lowermost Eocene ash marker; A: lower Miocene; $\mathrm{A}^{\prime}$ : middle Oligocene; $\mathrm{O}^{\prime}$ : base Pliocene. Slices based on seismic interpretation by Skogseid and Eldholm (this volume). 
ditional mechanism for relative uplift just west of the escarpment. Accordingly, the landward limit of the inner flows (Fig. 2), and not the escarpment, defines the feather-edge of the extrusive lavas.

\section{Paleoceanographic Implications}

During most of the Cenozoic the Norwegian-Greenland Sea has been a major gateway for the transport of cold polar water masses to the North Atlantic Ocean, balanced by advection of warmer waters into the polar basins. The temporal and spatial evolution of this gateway has significantly influenced the paleoenvironment of large parts of the world's ocean (Thiede et al., this volume). It has become fashionable to link environmental signals in seafloor sediments to major plate tectonic and other structural events, often assuming a sudden and simple tectonic evolution. In the Norwegian-Greenland Sea, the surface as well as deep-water circulation are thought to be governed by the initiation of spreading between northeast Greenland and Svalbard, and the submergence of the Greenland-Scotland transverse ridge (Thiede, 1979; Eldholm and Thiede, 1980). Here, we only point out that the volcanic and tectonic history of the Vøring Plateau, derived from Leg 104 results, have provided new and important data to understand the distribution and circulation of the water masses in the Cenozoic Norwegian-Greenland Sea.

During long periods in the Paleogene, the Norwegian-Greenland Sea may have consisted of a series of separate basins with no, or poor, deep-water interchange. For example, a deep-water connection between the Norway Basin and the Lofoten-Greenland Basin (Fig. 1) was developed as late as the early middle Eocene time. The data from the Vøring marginal high suggest that it was elevated both with respect to the growing ocean basin in the west and to the eastern Vøring Basin. If we assume a similar history of evolution for the Faeroe-Shetland and the Greenland marginal highs, we cannot avoid concluding that these features have had a profound influence on the water mass distribution and deep-water circulation and exchange in the Eocene, and to a lesser extent also in the Oligocene. The depositional consequences of this complex paleoceanographic situation have not been investigated previously. Actually, restricted late Paleoceneearly Eocene basins combined with a hot and moist climate (Froget et al., this volume), might have had an impact on the resource potential of the margin.

The main unconformity (reflector A, Fig. 17) at the outer Vøring Margin is overlain by lower Miocene sediments and therefore not related to the middle Oligocene global drop in sea level. Nevertheless, a less distinct mid-Oligocene unconformity (reflector $A^{\prime}$, Fig. 17) is recognized in the seismic record. It appears that the prominent lower Miocene horizon marks the transition from a marginal high of greatly varying relief that was still being eroded, to a gently subsiding high being blanketed by deep-water pelagic sediments.

\section{SUMMARY AND CONCLUSIONS}

The recovery of more than $900 \mathrm{~m}$ of igneous rocks and interbedded sediments at Site 642 is one of the major achievements during the first four years of ODP drilling. The two volcanic series at Site 642, as well as the sediments at all three sites, have provided data of high quality that improve our understanding of the Vøring Margin. In particular, the results are relevant for studying the events during initial opening of a volcanic margin. We have shown that the early Vøring Margin developed as a part of the NAVP, and that the drilling results have a strong bearing on the evolution of volcanic margins in general.

The incipient early Cenozoic rifting in the North Atlantic followed the more than 2000 -km-long Reykjanes-Mohns Line (Fig. 10). The actual breakup occurred in areas of varying sediment cover and crustal thickness. At the Vøring Margin, open- ing took place within a basin province that had previously undergone several episodes of crustal extension, the most recent being a Late Jurassic-Early Cretaceous tectonic phase that structured the margin in a system of well-defined fault blocks (Fig. 2). The sedimentary Vøring Basin was formed by subsequent regional subsidence in the Cretaceous, a period without significant structural deformation.

The Vøring Basin again came under tension in the earliest Tertiary. Lithospheric thinning was first accompanied by dike injection in the lower crust and uplift over the rising asthenosphere, followed by erosion of the inverted area with redeposition in the adjacent basins. Just prior to breakup, the crust was gradually thinned and extended by pervasive injection of intrusives and listric normal faulting in the outer Vøring Basin. During this period, magma from relatively shallow crustal melts penetrated the surface, forming the dacitic extrusives of the Site 642 lower series (Fig. 12). The crustal breakup, during Chron $24.2 \mathrm{R}$ at about $57.5 \mathrm{Ma}$, was accompanied by a surge of excessive volcanism producing a subaerial flow complex presently constituting the upper flow-sill complex east of the escarpment, and the sub-basement reflectors in Zones II and III including the main seaward-dipping wedge (Figs. 7 and 12). These extrusives comprise the tholeiitic upper series at Site 642. Magma extrusion was most intense for an about 1-m.y. period after breakup, abating rapidly over the next $1 \mathrm{~m}$.y. The excellent flow properties of the basaltic lavas of the upper series, combined with their high production rate, constructed a tholeiitic extrusive edifice covering both the new oceanic crust and the adjacent thinned and contaminated continental crust. Thus, the lower series was emplaced during the late rift stage, and the upper series by subaerial accretion of oceanic magma during the initial drift stage of passive margin formation.

In our emplacement model, we follow Skogseid and Eldholm (1987), and place the boundary between continental and oceanic basement at the seaward termination of reflector $\mathrm{K}$, which marks the start of a region without a seismic base to the dipping reflectors. The stratigraphy of the seaward-dipping reflector wedge is produced by applying the Pálmason $(1973,1980)$ kinematic model for Icelandic crust as shown by Mutter et al. (1982). However, we document an asymmetry of marginal features created during initiation of opening. For this reason, we argue that extension by simple shear could have ocurred between the Jan Mayen and Greenland-Senja Fracture Zones. By invoking an asymmetric model with listric faulting, we provide an additional tectonic force consistent with the large magnitude of the synconstructional subsidence of the seaward-dipping reflectors, the tilting of the marginal high, and the Eocene movements at the Vøring Plateau Escarpment. The movements beneath the escarpment, which probably followed pre-existing Mesozoic structures, waned in the Oligocene. The region between the continent/ocean boundary and the landward limit of the sill-flow complex is underlain by thinned continental crust highly intruded by dikes and sills. Site 642 documents magmatic activity both before and after breakup, and the term transitional crust is suggested for this region (Fig. 7).

The region of excessive igneous activity is balanced by a root of possible underplated crust. The shallow basement relief of the marginal high reflects the isostatic response to the abnormal crustal load. However, about 4 m.y. after breakup, the injection center had subsided to the present accretionary level. Subsequently, regional thermal subsidence dominates, with sedimentation gradually smoothing the relief and overflowing the marginal high (Fig. 17).

The above scenario does not include many of the subtle compositional and geochemical differences reflecting variations in magma generation and emplacement. For example, it is known from Iceland that the constructional process of crustal accretion 
includes discrete but closely associated events of extrusive volcanism, faulting, and fissuring, creating overlapping spreading centers, transient fissure swarms, and central volcanoes (Pálmason, 1988). We have assumed an analog situation at the Vøring Plateau, noting that a single drill hole only samples one locality, whereas the geophysical surface data represent an integrated pattern. Hence, a full understanding of the processes acting during opening requires a transect or grid of drill holes. On the other hand, we differ from many previous investigators by incorporating the entire marginal high and the adjacent basin in the evolutionary model. This is based on the view that the dipping reflectors, being the expression of certain geologic conditions, represent only one element of a complex breakup process.

The composition and time of emplacement of the upper series demonstrate that the rocks belong to the NAVP. We find that NAVP consists of two different elements with respect to the North Atlantic. One is a broad, transverse volcanic trail, related to the Iceland hotspot, from Great Britain to Baffin Bay, along which extrusive activity has taken place throughout the Cenozoic. The other, a longitudinal element, consists of a series of extrusive complexes representing a transient surge of volcanism along and in the vicinity of the incipient plate boundary from 55 to $75^{\circ} \mathrm{N}$. The vast majority of these rocks, which overlie both old continental crust and young oceanic crust, were emplaced within a time period of $3 \mathrm{~m}$.y.

Analysis of the often scarce and uncertain age data shows that extrusive tholeiitic basalts were emplaced before and after the start of spreading. However, most pre-breakup lavas occur within, and south of, the transverse part of NAVP. This might indicate a slight northward propagation during the rifting stage. Nevertheless, the opening of the entire ocean was abrupt, and a duration of $1 \mathrm{~m} . \mathrm{y}$. is probably an upper limit. The subaerial volcanism and high rate of magma production during breakup are correlated with the most prominent of a series of pyroclastic horizons recognized over large areas in the North Atlantic realm. Hence, the opening has a traceable, far-extending signature in the seismic record. The origin and mode of transport of these lower Tertiary pyroclastics have been the focus of considerable discussion. We believe that a huge volcanic range between Norway and Greenland, providing a source for the ashes and tuffs, must have had a severe environmental impact over a large area.

The recognition of intense volcanic activity during the initial evolution of many margins has led to a classification into volcanic and nonvolcanic passive continental margins. To some extent the Vøring Margin has become an end-member of volcanic margin evolution. The nonvolcanic type, associated with evidence of major extensional tectonism, e.g., Bay of Biscay, shows little or no eruptive activity during extension. Conversely, the fact that the volcanic type is commonly without clearly developed extensional faults has been thought to imply a non-extensional nature. Most evolutionary models have been symmetric, based on pure-shear models. The asymmetric and extensional features at the Vøring Margin indicate that the term non-extension is not applicable. However, uplift during rifting, also documented at the west Rockall Margin (Roberts and Ginzburg, 1984), might be a more characteristic feature.

Most models of volcanic margins evolution incorporate a varying degree of partial melting during breakup. Whether or not the increased temperature of a hotspot centered around a mantle plume is the source of the melting is a matter of controversy (White et al., 1987a; Mutter et al., 1988). Our preferred model is based on a combination of increased temperatures at the base of the lithosphere and the pre-rifting crustal configuration. The plate boundary in the North Atlantic has been underlain by anomalously hot asthenosphere throughout Cenozoic times, and the crust in the Vøring Basin had been extended prior to the Cenozoic. These conditions will produce excess magma and provide initial uplift observed at the Vøring Plateau if the asthenospheric temperature is raised only by about $50^{\circ} \mathrm{C}(\mathrm{Pe}-$ dersen and Skogseid, this volume). Shortly after opening, the excess rate of magma production, and spreading rate, abates rapidly. The marginal high is created as a pronounced depth anomaly by isostatic compensation of the surface load, either by underplating or some other mechanism. This concept is not necessarily dependent on a hotspot, although we believe the Icelandic hotspot has contributed in a major way to initiating and maintaining the increased thermal field in the North Atlantic.

We conclude with some remarks about the seaward-dipping reflector sequences recognized in many of the world's oceans. First, extrusive magmatic rock complexes constructed subaerially or at shallow water depths are emplaced in an episodic manner. Thus, one would expect a depth section exhibiting varying amounts of sediments and changes in physical and chemical properties between individual and composite flow units. This has been documented in field sections and by Site 642 . In turn, these changes might produce significant depth variations in acoustic impedance. An example is the fine- and mediumgrained lava series at Site 642 (Fig. 6) (Eldholm, Thiede, Taylor et al., 1987). Consequently, it is not surprising to find well-defined sub-basement reflectors. The actual seismic pattern of the extrusive complex will, however, be the combined effect of the mode of construction and syndepositional and postdepositional deformation and subsidence. To develop a meaningful discussion of the origin of seaward-dipping reflectors, they should be classified according to the magnitude and character of the individual and composite sets of reflectors. For example, distinct, deep and divergent, arcuate wedges seem to mirror excess subaerial lava production accompanied by rapid syndepositional subsidence of the oceanic crust. On the other hand, the secondary wedge (Zone IIIB) at the Vøring Plateau probably reflects a normal production rate of marine extrusive magma, whereas some of the pre-opening flows at west Rockall Margin might have acquired their present dip by post-opening marginal subsidence. Observations of this kind most likely suggest a variety of intermediate margin styles between the end-members of volcanic and nonvolcanic passive margins, as exemplified by the Vøring and Bay of Biscay margins, respectively.

\section{ACKNOWLEDGMENTS}

We are grateful to Jakob Skogseid and Tom Pedersen for discussions and valuable assistance during the final phase of this project. We also benefitted from discussions with Robert M. Goll, Steinar T. Gudlaugsson, Svein Manum, and Annik M. Myhre, and from early preprints provided by Andy C. Morton, R.W.O'B. Knox, and Lindsay M. Parson. We thank Christine Yokley for drafting Figure 6 and Annik M. Myhre for permission to reproduce seismic profiles NOR-JM 9-10. James A. Austin, Jr. and Andy C. Morton reviewed the paper critically. This project has been supported by grants from the Norwegian Research Council for Science and the Humanities and Statoil (OE); Deutsche Forschungsgemeinschaft (DFG, Th200/3-3-5) (JT); and the National Science Foundation through Joint Oceanographic Institutions, Inc. (ET).

\section{REFERENCES}

Abrahamsen, N., Schoenharting, G., and Heinesen, M., 1984. Palaeomagnetism of the Vestmanna core and magnetic age and evolution of the Faeroe Islands. Ann. Soc. Scient. Faeroensis Suppl., 9:193-198.

Austin, J. A., Jr., and Uchupi, E., 1982. Continental-oceanic crustal transition off Southwest Africa. AAPG Bull., 66:1328-1347.

Bally, A. W., 1983. Seismic expression of structural styles. AAPG Stud. Geol., 15.

Berggren, W. A., Kent, D. V., Flynn, J. J., and Van Couvering J. A., 1985. Cenozoic geochronology. Geol. Soc. Am. Bull., 96:1407-1418.

Bott, M.H.P., 1976. Formation of sedimentary basins of the graben type by extension of the continental lithosphere. Tectonophysics, 36 : 77-86.

Bott, M.H.P., 1985. Plate tectonic evolution of the Icelandic transverse ridge and adjacent regions. J. Geophys. Res., 90:9953-9960. 
Bott, M.H.P., 1987. The continental margin of central East Greenland in relation to North Atlantic plate tectonic evolution. Spec. Publ., J. Geol. Soc. London, 144:561-568.

Bott, M.H.P., 1988. A new look at the causes and consequences of the Icelandic hot-spot. In Morton, A. C., and Parson, L. M. (Eds.), Early Tertiary volcanism and the opening of the NE Atlantic. Spec. Publ. Geol. Soc. London, 39:15-23.

Brooks, C. K., 1973. Tertiary of Greenland-A volcanic and plutonic record of continental break-up. Mem. AAPG, 19:150-160.

Brooks, C. K., and Gleadow, A.J.W., 1977. A fission-track age for the Skaergaard intrusion and the age of the East Greenland basalts. Geology, 5:539-540.

Brooks, C. K., and Nielsen, T.F.D., 1982. The East Greenland continental margin: a transition between oceanic and continental magmatism. $J$. Geol. Soc. London, 139:265-275.

Brooks, C. K., Pedersen, A. K., and Rex, D. C., 1979, The petrology and age of alkaline mafic lavas from the nunatak zone of central East Greenland. Bull. Gronlands Geologiske Undersøgelse, 123.

Bugge, T., Prestvik, T., and Rokoengen, K., 1980. Lower Tertiary volcanic rocks off Kristiansund-mid Norway. Mar. Geol., 35:277-286.

Caston, V.N.D., 1976. Tertiary sediments of the Vøring Plateau, Norwegian Sea, recovered by Leg 38 Of the Deep Sea Drilling Project. In Talwani, M., Udintsev, G., et al., Init. Repts. DSDP, 38: Washington (U.S. Govt. Printing Office), 761-782.

Cochran, J. R., and Talwani, M., 1977. Free-air gravity anomalies in the world's oceans and their relationship to residual elevation. Geophys. J. R. Astron. Soc., 50:495-552.

Cochran, J. R., and Talwani, M., 1978. Gravity anomalies, regional elevation, and the deep structure of the North Atlantic. J. Geophys. Res., 83:4907-4924.

Courtillot, V., Besse, J., Vandamme, D., Montigny, R., Jaeger, J.-J., and Capetta, H., 1986. Deccan flood basalts at the Cenozoic/Tertiary boundary? Earth Planet. Sci. Lett., 80:361-374.

Courtney, R. C., and White, R. S., 1986. Anomalous heat flow and geoid across the Cape Verde Rise: evidence for dynamic support from a thermal plume in the mantle. Geophys. J., 87:815-867.

Duddy, I. R., Gleadow, A.J.W., and Keene, J. B., 1984. Fission track dating of apatite and sphene from Paleogene sediments of Deep Sea Drilling Project Leg 81, Site 555. In Roberts, D. G., Schnitker, D., et al., Init. Repts. DSDP, 81: Washington (U.S. Govt. Printing Office), 725-729.

Eldholm, O., and Thiede, J., 1980. Cenozoic continental separation between Europe and Greenland. Palaeogeogr. Palaeoclimat. Palaeoecol., 30:243-259.

Eldholm, O., and Windisch, C. C., 1974. Sediment distribution in the Norwegian-Greenland Sea. Geol. Soc. Am. Bull., 85:1661-1676.

Eldholm, O., and Mutter, J. C., 1986. Basin structure on the Norwegian Margin from analysis of digitally recorded sonobuoys. J. Geophys. Res., 91:3763-3783.

Eldholm, O., Sundvor, E., and Myhre, A., 1979. Continental margin off Lofoten-Vesterålen, Northern Norway. Mar. Geophys. Res., 4: 3-35.

Eldholm, O., Skogseid, J., Sundvor, E., and Myhre, A. M., 1989. The Norwegian-Greenland Sea. In Grantz, A., Johnson, G. L., and Sweeney, J. (Eds.), The Arctic Ocean Region, Vol. L, The Geology of North America: Boulder (DNAG, Geol. Soc. Am.).

Eldholm, O., Sundvor, E., Myhre, A. M., and Faleide, J. I., 1984. Cenozoic evolution of the continental margin off Norway and western Svalbard. In Spencer, A. M., et al. (Eds.), Petroleum Geology of the North European Margin: London (Graham and Trotman), 3-28.

Eldholm, O., Thiede, J., Taylor, E. et al., 1987. Proc. ODP, Init. Repts., 104: College Station, TX (Ocean Drilling Program).

Eldholm, O., Thiede, J., Taylor, E. et al., 1987. Summary and preliminary conclusions, ODP Leg 104. In Eldholm, O., Thiede, J., Taylor, E., et al., Proc. ODP, Init. Repts., 104: College Station, TX (Ocean Drilling Program), 751-771.

Faleide, J. I., Myhre, A. M., and Eldholm, O., 1988. Early Tertiary volcanism at the western Barents Sea margin. In Morton, A. C., and Parson, L. M. (Eds.), Early Tertiary volcanism and the opening of the NE Atlantic. Spec. Publ., Geol. Soc. London, 39:135-146.

Featherstone, P. S., Bott, M.P.H., and Peacock, J. H., 1977. Structure of the continental margin of southeastern Greenland. Geophys. J. R. Astron. Soc., 48:15-27.
Gariépy, C., Ludden, J., and Brooks, C., 1983. Isotopic and trace element constraints on the genesis of the Faeroe lava pile. Earth Planet. Sci. Lett., 63:257-272.

Gatliff, R. W., Hitchen, K., Ritchie, J. D., and Smythe, R. K., 1984. Internal structure of the Erlend Tertiary volcanic complex, north of Shetland, revealed by seismic reflection. J. Geol. Soc. London, 141: $555-562$.

Gerrard, I., and Smith, G. C., 1983. Post-Paleozoic succession and structure of the southwestern African continental margin. AAPG Mem., 34:49-74.

Gibb, F.G.F., and Kanaris-Sotiriou, R., 1988. The geochemistry and origin of the MORB-type Faeroes-Shetland Tertiary sill complex. In Morton, A. C., and Parson, L. M. (Eds.), Early Tertiary volcanism and the opening of the NE Atlantic. Spec. Publ., Geol. Soc. London. 39:241-252.

Gibb, F.G.F., Kanaris-Sotiriou, R., and Neves, R., 1986. A new Tertiary sill complex of mid-ocean ridge basalt type NNE of the Shetland Isles: A preliminary report. Trans. R. Soc. Edinburgh: Earth Sci., $77: 223-230$

Gibson, I. L., and Gibbs, A. D., 1987. Accretionary volcanic processes and the crustal structure of Iceland. Tectonophysics, 133:57-64.

Greeley, R., 1982. The Snake River Plain, Idaho: Representative of a new category of volcanism. J. Geophys. Res., 87:2705-2712.

Hagevang, T., Eldholm, O., and Aalstad, I., 1983. Pre-23 magnetic anomalies between Jan Mayen and Greenland-Senja fracture zones in the Norwegian Sea. Mar. Geophys. Res., 5:345-363.

Hailwood, E. A., and Knox, R.W.O'B., 1988. Magnetostratigraphy of the basal Eocene volcanic ash series of NW Europe. Newsl. Geol. Soc. London, 15:44.

Hald, N., 1978. Tertiary igneous activity at Giesecke Bjerge, northern East Greenland. Bull. Geol. Soc. Denmark, 27:109-115.

Hald, N., and Waagstein, R., 1983. Silicic basalts from the Faeroe Islands: Evidence of crustal contamination. In Bott, M.H.P., Saxov, S., Talwani, M., and Thiede, J. (Eds.), Structure and Development of the Greenland-Scotland Ridge-New Methods and Concepts: New York (Plenum Press), 343-349.

Hald, N., and Waagstein, R., 1984. Lithology and chemistry of a 2-km sequence of lower Tertiary tholeiitic lavas drilled on Suderoy, Faeroe Islands (Lopra-1). Ann. Soc. Scient. Faeroensis Suppl., 9:16-38.

Haq, B. U., Hardenbol, J., and Vail, P. R., 1987. Chronology of fluctuating sea levels since the Triassic. Science, 235:1156-1167.

Higgins, A. C., and Soper, N. J., 1981. Cretaceous-Paleocene sub-basaltic and intrabasaltic sediments of the Kangerslugssuaq area, central East Greenland. Geol. Mag., 118:337-448.

Hinz, K., 1981. A hypothesis on terrestrial catastrophes: Wedges of very thick oceanward dipping layers beneath passive margins-their origin and paleoenvironmental significance. Geol. Jahrb., E22:3-28.

Hinz, K., and Schlüter, H. U., 1978. Der Nordatlantik-Ergebnisse geophysikalischer Untersuchungen der Bundesanstalt für Geowissenschaften und Rohstoffe an nordatlantischen Kontinentalrändern. Erdoel-Erdgas-Z., 94:271-280.

Hinz, K., and Weber, J., 1976. Zum geologischen Aufbau des Norwegischen Kontinentalrandes und der Barents-See nach reflexionsseismischen Messungen. Erdoel \& Kohle, Erdgas, Petrochem., 3-29.

Hinz, K., Dostman, H. J., and Hanisch, J., 1982. Structural framework of the Norwegian Sea. In Offshore Northern Seas: Oslo (Norwegian Petrol. Soc.). Oslo.

Hinz, K., Dostman, H. J., and Hanisch, J., 1984. Structural elements of the Norwegian Sea continental margin. Geol. Jahrb., A75:193211.

Hinz, K., Mutter, J. C., Zehnder, C. M., and NGT Study Group, 1987. Symmetric conjugation of continent-ocean boundary structures along the Norwegian and East Greenland margins. Mar. Petrol. Geol., 4: 166-187.

Hitchen, K., and Ritchie, J. D., 1988. Geological review of the west Shetland area. In Brooks, J., and Glennie, K. (Eds.), Petroleum Geology of North West Europe: London (Graham \& Trotman), 737749.

Hyndman, R. D., and Roberts, D. G., 1987. Deep Sea Drilling Project heat flow and models of the rifted west Rockall Margin. J. Geophys. Res., 92:9376-9384.

Jacqué, M., and Thouvenin, J., 1975. Lower Tertiary tuffs and volcanic activity in the North Sea. In Woodland, A. M. (Ed.), Petroleum and 
the Continental Shelf of North-west Europe. Vol. 1: London (Applied Science Publications), 455-465.

Kaminski, M. A., 1987. Cenozoic deep-water agglutinated foraminifera in the North Atlantic. [Ph.D. thesis]. Woods Hole Oceanogr. Inst., Mass.

Kent, D. V., and Opdyke, N. D., 1978. Paleomagnetism and magnetic properties of igneous rocks samples-Leg 38. In Talwani, M., Udintsev, G., et al., Init. Repts. DSDP, 38 (Suppl.): Washington (U.S. Govt. Printing Office), 3-8.

Kharin, G. N., 1976. The petrology of magmatic rocks, DSDP Leg 38. In Talwani, M., Udintsev, G., et al., Init. Repts. DSDP, 38: Washington (U.S. Govt. Printing Office), 685-715.

Kharin, G. N., Udintsev, G. B., Bogatikov, O. A., Dmitriev, J. I., Raschka, H., Kruezer, H., Mohr, M., Harre, W., and Eckhardt F-J., 1976. K/Ar age of the basalts of the Norwegian-Greenland Sea Glomar Challenger, Leg 38 DSDP. In Talwani, M., Udintsev, G., et al., Init. Repts. DSDP, 38: Washington (U.S. Govt. Printing Office), 755-759.

Knox, R.W.O'B., 1984. Nannoplankton zonation and the Palaeocene/ Eocene boundary beds of NW Europe: An indirect correlation by means of volcanic ash layers. J. Geol. Soc. London., 141:993-999.

Knox, R.W.O'B., and Morton, A. C., 1983. Stratigraphic distribution of early Palaeogene pyroclastic deposits in the North Sea Basin. Proc. Yorkshire Geol. Soc., 44:355-363.

Knox, R.W.O'B., and Morton, A. C., 1988: The record of early Tertiary $\mathrm{N}$ Atlantic volcanism in sediments of the North Sea Basin. In Morton, A. C., and Parson, L. M. (Eds.), Early Tertiary volcanism and the opening of the NE Atlantic. Spec. Publ., Geol. Soc. London, 39:407-419.

Larsen, H. C., 1978. Offshore continuation of East Greenland dyke swarm and North Atlantic Ocean formation. Nature, 274:220-223.

Larsen, H. C., 1980. Geological perspectives of the East Greenland continental margin. Bull. Geol. Soc. Denmark, 29:77-101.

Larsen, H. C., 1984. Geology of the East Greenland Shelf. In Spencer, A. M., et al. (Eds.), Petroleum Geoloqy of the North European Margin: London (Graham and Trotman), 329-339.

Larsen, H. C., 1988. A multiple and propagating rift model for the NE Atlantic. In Morton, A. C., and Parson, L. M. (Eds.), Early Tertiary volcanism and the opening of the NE Atlantic. Spec. Publ., Geol. Soc. London, 39:157-158.

Larsen, H. C., and Jakobsdóttir, S., 1988. Distribution, crustal properties, and significance of seawards-dipping sub-basement reflectors off E Greenland. In Morton, A. C., and Parson, L. M. (Eds.), Early Tertiary volcanism and the opening of the NE Atlantic. Spec. Publ., Geol. Soc. London, 39:95-113.

Larsen, L. M., and Watt, W. S., 1985. Episodic volcanism during breakup of the North Atlantic: Evidence from the East Greenland plateau basalts. Earth Planet. Sci. Lett., 73:105-116.

Le Pichon, X., and Sibuet, J.-C., 1981. Passive margins: A model of formation. J. Geophys. Res., 86:3708-3720.

Lister, G. S., Etheridge, M. A., and Symonds, P. A., 1986. Detachment faulting and the evolution of passive continental margins. Geology, $14: 246-250$.

Lowell, J. D., and Genik, G. J., Sea-floor spreading and structural evolution of southern Red Sea. AAPG Bull., 55:247-259.

Lund, J., 1983, Biostratigraphy of interbasaltic coals from the Faeroe Islands. In Bott, M.H.P., Saxov, S., Talwani, M., and Thiede, J. (Eds.), Structure and Development of the Greenland-Scotland RidgeNew Methods and Concepts: New York (Plenum Press), 417-423.

MacIntyre, R. M., and Hamilton, P. J., 1984. Isotopic geochemistry of lavas from Sites 553 and 555. In Roberts, D. G., Schnitker, D., et al., Init. Repts. DSDP, 81: Washington (U.S. Govt. Printing Office), 775-781.

Malm, O. A., Christensen, O. B., Furnes, H., Løvlie, R., Rueslåtten, H., and Østby. K. L., 1983. The lower Tertiary Balder Formation: An organogenic and tuffaceous deposit in the North Sea region. In Spencer, A. M., et al., (Eds.), Petroleum Geology of the North European Margin: London (Graham and Trotman), 149-170.

Meissner, R., and Köpnick, M., 1987. Structure and evolution of passive margins: The plume model again. In SfB 313 Sedimentation im Europäischen Nordmeer: Kiel (University of Kiel), 544-565.

Merriman, R. J., Taylor, P. N., and Morton, A. C., 1988. Petrochemistry and isotope geochemistry of early Palaeogene basalts forming the dipping reflector sequence SW of Rockall Plateau, NE Atlantic. In Morton, A. C., and Parson, L. M. (Eds.), Early Tertiary volcan- ism and the opening of the NE Atlantic. Spec. Publ., Geol. Soc. London, 39:123-134.

Montadert, L., Roberts, D. G., et al., 1979. Init. Repts. DSDP, 48: Washington (U.S. Govt. Printing Office).

Morton, A. C., and Keene, J. B., 1984. Palaeogene pyroclastic volcanism in the southwest Rockall Plateau. In Roberts, D. G., Schnitker, D., et al., Init. Repts. DSDP, 81: Washington (U.S. Govt. Printing Office), 633-643.

Morton, A. C., and Taylor, P. N., 1987. Lead isotope evidence for the structure of the Rockall dipping-reflector passive margin. Nature, 326: 381-383.

Morton, A. C., Evans, D., Harland, R., King, C., and Ritchie, D. K., 1988a. Volcanic ash in a cored borehole W of the Shetland Islands: evidence for Selandian (late Palaeocene) volcanism in the Faeroes region. In Morton, A. C., and Parson L. M. (Eds.), Early Tertiary volcanism and the opening of the NE Atlantic. Spec. Publ., Geol. Soc. London, 39:263-269.

Morton, A. C., Dixon, J. E., Fitton, J. G., Macintyre, R. M., Smythe, D. K., and Taylor, P. N., 1988b. Early Tertiary rocks in Well 163/ 6-1A, Rockall Trough. In Morton, A. C., and Parson, L. M. (Eds.), Early Tertiary volcanism and the opening of the NE Atlantic. Spec. Publ., Geol. Soc. London, 39:293-308.

Mutter, J. C., 1984. Cenozoic and late Mesozoic stratigraphy and subsidence history of the Norwegian margin. Bull. Geol. Soc. Am., 95: $1135-1149$.

Mutter, J. C., and Zehnder, C. M., 1988. Deep crustal study of magmatic processes: the inception of seafloor spreading in the Norwegian-Greenland Sea. In Morton, A. C., and Parson, L. M. (Eds.), Early Tertiary volcanism and the opening of the NE Atlantic. Spec. Publ., Geol. Soc. London, 39:35-48.

Mutter, J. C., Buck, W. R., and Zehnder, C. M., 1988. Convective partial melting. 1. A model for the formation of thick basaltic sequences during the initiation of spreading. J. Geophys. Res., 93:1031-1048.

Mutter, J. C., Talwani, M., and Stoffa, P. L., 1982. Origin of seawarddipping reflectors in oceanic crust off the Norwegian margin by "subaerial sea-floor spreading." J. Geophys. Res., 89:483-502.

Mutter, J. C., Talwani, M., and Stoffa, P. L., 1984. Evidence for a thick oceanic crust adjacent to the Norwegian margin. J. Geophys. Res., $89: 483-502$.

Myhre, A. M., 1984. Compilation of seismic velocity measurements along the margins of the Norwegian-Greenland Sea. Norsk Polarinst. Skr., 180:41-61.

Myhre, A. M., and Eldholm, O., 1988. The western Svalbard margin $\left(74-80^{\circ}\right.$ N). Mar. Pet. Geol., 5:134-156.

Neumann, E-R., and Schilling, J-G., 1984. Petrology of basalts from Mohns-Knipovich Ridge; The Norwegian-Greenland Sea. Contrib. Mineral. Petrol., 85:209-223.

Nielsen, T.F.D., 1987. Tertiary alkaline magmatism in East Greenland: a review. In Fitton, J. G., and Upton, B.J.G. (Eds.), Alkaline Igneous Rocks: Spec. Publ., Geol. Soc. London, 30:489-515.

Nielsen, T.F.D., and Brooks, C. K., 1981. The E. Greenland rifted continental margin: an examination of the coastal flexure. J. Geol. Soc. London, 138:559-568.

Noe-Nygaard, A., 1974. Cenozoic to Recent volcanism in and around the North Atlantic Basin. In Nairn, A.E.M., and Stehli, F. G. (Eds.), The Ocean Basins and Margins. Vol. 2, The North Atlantic: New York (Plenum Press), 391-443.

Odin, G. S., and Mitchell, J. G., 1983. Dating of the Palaeocene-Eocene Group basalts. Scoresbysund, East Greenland: a review. Newsl. Stratigr., 12:112-121.

Ólafsson, I., 1988. Deep crustal structure of the Møre margin from analysis of two-ship multichannel seismic data [Dr. Sci. thesis]. University of Bergen, Norway.

Pálmason, G., 1973. Kinematics and heat flow in a volcanic rift zone, with application to Iceland. R. Astron. Soc. Geophys. J., 33:451-481.

Pálmason, G., 1980. A continuum model of crustal generation in Iceland: kinematic aspects. J. Geophys., 47:7-18.

Pálmason, G., 1988. Model of crustal formation in Iceland, and application to submarine mid-ocean ridges. In Vogt, P. R., and Tucholke, B. E. (Eds.), The geology of North America, Vol. M: Boulder (DNAG Geol. Soc. Am.), 87-97.

Parson, L., and ODP Leg 104 Scientific Party, 1988: Dipping reflector styles in the northeast Atlantic Ocean. In Morton, A. C., and Parson, L. M. (Eds.), Early Tertiary Volcanism and the Opening of the NE Atlantic: Spec. Publ., Geol. Soc. London, 39:57-68. 
Parsons, B., and Sclater, J. G., 1977. An analysis of the variation of ocean floor heat flow and bathymetry with age. J. Geophys. Res., 82:803-827.

Perry, F. P., Baldridge, W. S., and DePaolo, D. J., 1987. Role of asthenosphere and lithosphere in the genesis of late Cenozoic basaltic rocks from the Rio Grande Rift and adjacent regions of the southwestern United States. J. Geophys. Res., 92:9193-9213.

Perry, R. B., Flemming, H. S., Cherkis, N. Z., Feden, R. H., and Vogt, P. R., 1980. Bathymetry of the Norwegian-Greenland and western Barents seas. Map, U.S. Naval Res. Lab., Washington, D.C.

Richardson, C., Oakley, P. J., and Cann, J. R., 1984. Trace and major element geochemistry of basalts from Leg 81 . In Roberts, D. G. Schnitker, D., et al., Init. Repts. DSDP, 81: Washington (U.S. Govt. Printing Office), 795-806.

Ridd, M. F., 1983. Aspects of the Tertiary geology of the Faeroe-Shetland channel. In Bott, M.H.P., Saxov, S., Talwani, M., and Thiede, J. (Eds.), Structure and Development of the Greenland-Scotland Ridge-New Methods and Concepts: New York (Plenum Press), 91-108.

Ridley, W. I., 1976. A synthesis of the magmatic evolution of the BritoArctic Province, including data from DSDP Leg 38. In Talwani, M., Udintsev, G., et al., 1976. Init. Repts. DSDP, 38: Washington (U.S. Govt. Printing Office), 751-753.

Roberts, D. G., and Ginzburg, A., 1984. Deep crustal structure of southwest Rockall Plateau. Nature, 308:435-439.

Roberts, D. G., Montadert, L., and Searle, R. C., 1979. The western Rockall Plateau: stratigraphy and structural evolution. In Montadert, L., Roberts, D. G., et al., Init. Repts DSDP, 48: Washington (U.S. Govt. Printing Office), 1061-1088.

Roberts, D. G., Morton, A. C., and Backman, J., 1984a. Late Paleocene-Eocene volcanic events in the northern North Atlantic Ocean. In Roberts, D. G., Schnitker, D., et al., Init. Repts. DSDP, 81: Washington (U.S. Govt. Printing Office), 913-923.

Roberts, D. G., Ginzburg, A., Nunn, K., and McQuillin, R., 1988. The structure of the Rockall Trough from seismic refraction and wide-angle reflection measurements. Nature, 332:632-635.

Roberts, D. G., Backman, J., Morton, A. C., Murray, J. W. and Keene, J. B., 1984b. Evolution of volcanic rifted margins: Synthesis of Leg 81 results on the west margin of Rockall Plateau. In Roberts, D. G. Schnitker, D., et al., Init. Repts. DSDP, 81: Washington (U.S. Govt. Printing Office), 883-911.

Roberts, D. G., Schnitker, D., et al., 1984. Init. Repts. DSDP, 81: Washington (U.S. Govt. Printing Office).

Royden, L., Sclater, J. G., and Von Herzen, R. P., 1980. Continental margin subsidence and heat flow: Important parameters in formation of petroleum hydrocarbons. AAPG Bull., 64:173-187.

Schilling, J.-G., 1976. Rare-earth, $\mathrm{Sc}, \mathrm{Cr}, \mathrm{Fe}, \mathrm{Co}$, and $\mathrm{Na}$ abundances in DSDP Leg 38 basement basalts: Some additional evidence on the evolution of the Thulean Volcanic Province. In Talwani, M., Udintsev, G., et al., 1976, Init. Repts. DSDP, 38: Washington (U.S. Govt. Printing Office), 741-750.

Schilling, J.-G., and Noe-Nygaard, A., 1974. Faeroe-Iceland plume: Rare earth evidence. Earth Planet. Sci. Lett., 24:1-14.

Schilling, J.-G., Zajac, M., Evans, R., Johnston, T., White, W., Devine, D. J., and Kingsley, R., 1983. Petrology and geochemical variations along the mid-Atlantic ridge from $29^{\circ} \mathrm{N}$ to $73^{\circ}$ N. Am. J. Sci., 283: 510-586.

Schoenharting, G., and Abrahamsen, N., 1984. Magnetic investigations on cores from the Lopra-1 drillhole, Faeroe Islands. Ann. Soc. Scient. Faeroensis Suppl., 9:109-114.

Schrader, H-J., Bjørklund, K., Manum, S., Martini, E., and van Hinte, J., 1976. Cenozoic biostratigraphy, physical stratigraphy and paleoceanography in the Norwegian-Greenland Sea, DSDP Leg 38 paleontological synthesis. In Talwani, M., Udintsev, G., et al., 1976. Init. Repts. DSDP, 38: Washington (U.S. Govt. Printing Office), 1197-1211.

Sellevoll, M. A., and Mokhtari, M., 1988. An intra-oceanic crustal seismic reflecting zone below the dipping reflectors on Lofoten margin. Geology, 16:666-668.

Skogseid, J., and Eldholm, O., 1987. Early Cenozoic crust at the Norwegian continental margin and the conjugate Jan Mayen Ridge. $J$. Geophys. Res., 92:11471-11491.
Skogseid, J., and Eldholm, O., 1988. Early Cainozoic evolution of the Norwegian volcanic passive margin and the formation of marginal highs. In Morton, A. C., and Parson, L. M. (Eds.), Early Tertiary volcanism and the opening of the NE Atlantic. Spec. Publ., Geol. Soc. London, 39:49-56.

Smythe, D. K., 1983. Faeroe-Shetland Escarpment and continental margin north of the Faeroes. In Bott, M.H.P., Saxov, S., Talwani, M., and Thiede, J. (Eds.), Structure and Development of the GreenlandScotland Ridqe-New Methods and Concepts: New York (Plenum Press), 109-119.

Smythe, D. K., Chalmers, J. A., Skuce, A. G., Dobinson, A., and Mould, A. S., 1983. Early opening history of the North Atlantic. I. Structure and origin of the Faeroe-Shetland Escarpment. Geophys. J. R. Astron. Soc., 72:373-398.

Soper, N. J., and Costa L. 1., 1976. Palynological evidence for the age of Tertiary basalts and post-basaltic sediments at Kap Dalton, central East Greenland. Grønlands Geologiske Undersøkelse Rapport, 80:123-127.

Soper, N. J., Higgins, A. C., Downie, C., Matthews, D. W., and Brown, P. E., 1976. Late Cretaceous-early Tertiary stratigraphy of the Kangerdlugssuaq area, East Greenland, and the age of opening of the north-east Atlantic. J. Geol. Soc. London, 132:85-104.

Talwani, M., 1978. Distribution of basement under the eastern North Atlantic Ocean and the Norwegian Sea. Geol. J. Spec. Iss., 5:347-376.

Talwani, M., and Eldholm, O., 1972. The continental margin off Norway: A geophysical study. Geol. Soc. Am. Bull., 83:3375-3608.

Talwani, M., and Eldholm, O., 1977. Evolution of the Norwegian-Greenland Sea. Geol. Soc. Am. Bull., 88:969-999.

Talwani, M. and Udintsev, G., 1976. Tectonic synthesis. In Talwani, M., Udintsev, G., et al., Init. Repts. DSDP, 38: Washington (U.S. Govt. Printing Office), 1213-1242.

Talwani, M., Mutter, J. C., and Eldholm, O., 1981. The initiation of opening of the Norwegian Sea. Oceanologica Acta, SP:23-30.

Talwani, M., Mutter, J. C., and Hinz, K., 1983. Ocean/continent boundary under the Norwegian continental margin. In Bott, M.H.P., Saxov, S., Talwani, M., and Thiede, J. (Eds.), Structure and Development of the Greenland-Scotland Ridqe-New Methods and Concepts: New York (Plenum Press), 121-131.

Talwani, M., Mutter, J. C., Eldholm, O., and Stoffa, P.L., 1984. Comments on paper by Smythe et al. entitled "Early opening of the North Atlantic: 1. Structure and Origin of the Faeroe-Shetland Escarpment." Geophys. J. R. Astron. Soc., 78:627-637.

Talwani, M., Udintsev, G., et al., 1976. Init. Repts. DSDP, 38: Washington (U.S. Govt. Printing Office).

Thiede, J., 1979. Paleogeography and paleobathymetry of the Mesozoic and Cenozoic North Atlantic Ocean. GeoJournal, 3:263-272.

Thompson, L. N., Morrison, M. A., Dickin, A. P., Gibson, I. L., and Harmon, R. S., 1986. Two contrasting styles of interaction between basic magmas and continental crust in the British Tertiary Volcanic Province. J. Geophys. Res., 91:5985-5997.

Upton, B.G.J., 1988. History of Tertiary igneous activity in the N Atlantic borderlands. In Morton, A. C., and Parson, L. M. (Eds.), Early Tertiary volcanism and the opening of the NE Atlantic. Spec. Publ., Geol. Soc. London, 39:429-453.

Upton, B.G.J., Emeleus, C. H., and Beckinsale, R. D., 1984. Petrology of the Northern East Greenland Tertiary flood basalts: Evidence from Hold with Hope and Wollaston Forland. J. Petrol., 25:151184.

Upton, B.G.J., Emeleus, C. H., and Hald, N., 1980. Tertiary volcanism in northern Gauss Halvø and Hold with Hope. J. Geol. Soc. London, 137:491-508.

Vestby, J. I., 1980. Cenozoisk innsynkning av jordskorpen i Lofoten og Grønland bassengene med tilgrensende kontinentalmarginer. [Cand. Real. thesis]. University of Oslo, Norway.

Viereck, L. G., Taylor, P. N., Parson, L. M., Morton, A. C., Hertogen, J., Gibson, I. L., and the ODP Leg 104 Scientific Party, 1988. Origin of the Palaeogene Vøring Plateau volcanic sequence. In Morton, A. C., and Parson, L. M. (Eds.), Early Tertiary volcanism and the opening of the NE Atlantic. Spec. Publ., Geol. Soc. London, 39: 69-83.

Vink, G. E., 1982. Continental rifting and the implications for plate tectonic reconstructions. J. Geophys. Res., 87:10677-10688. 
Vink, G. E., 1984. A hotspot model for Iceland and the Vøring Plateau. J. Geophys. Res., 89:9949-9959.

Vogt, P. R., and Avery, O. E., 1974. Detailed magnetic surveys in the northeast Atlantic and the Labrador Sea. J. Geophys. Res., 79:363389.

Waagstein, R., 1988. Structure, composition and age of the Faeroe basalt plateau. In Morton, A. C., and Parson, L. M. (Eds.), Early Tertiary volcanism and the opening of the NE Atlantic. Spec. Publ., Geol. Soc. London, 39:225-238.

Walker, G.P.L., 1973. Lengths of lava flows. Phil. Trans. R. Soc. London, A274:197-118.

Walker, G.P.L., 1964. Geological investigations in eastern Iceland. Bull. Volc., 27:351-363.

White, R. S., 1988. A hot-spot model for early Tertiary volcanism in the N Atlantic. In Morton, A. C., and Parson, L. M. (Eds.), Early Tertiary volcanism and the opening of the NE Atlantic. Spec. Publ., Geol. Soc. London, 39:3-13.
White, R. S., Spence, G. D., Fowler, S. R., McKenzie, D. P., Westbrook, G. K., and Bowen, A. N., 1987a. Magmatism at rifted continental margins. Nature, 330:439-444.

White, R. S., Westbrook, G. K., Fowler, S. R., Spence, G. D., Barton, P. J., Joppen, M., Morgan, J., Bowen, A. N., Prescott, C., and Bott, M.H.P., 1987b. Hatton Bank (northwest U.K.) continental margin structure. Geophys. J. R. Astron. Soc., 89:265-272.

Whitmarsh, R. B., and Miles, P. R., 1987. Seismic structure of a seaward-dipping reflector sequence southwest of Rockall. Geophys. J. R. Astron. Soc., 90:731-739.

Zielinski, G. W., 1979. On the thermal evolution of passive continental margins, thermal depth anomalies, and the Norwegian-Greenland Sea. J. Geophys. Res., 84:7577-7588.

Date of initial receipt: 26 August 1988

Date of acceptance: 10 February 1989

Ms 104B-191 